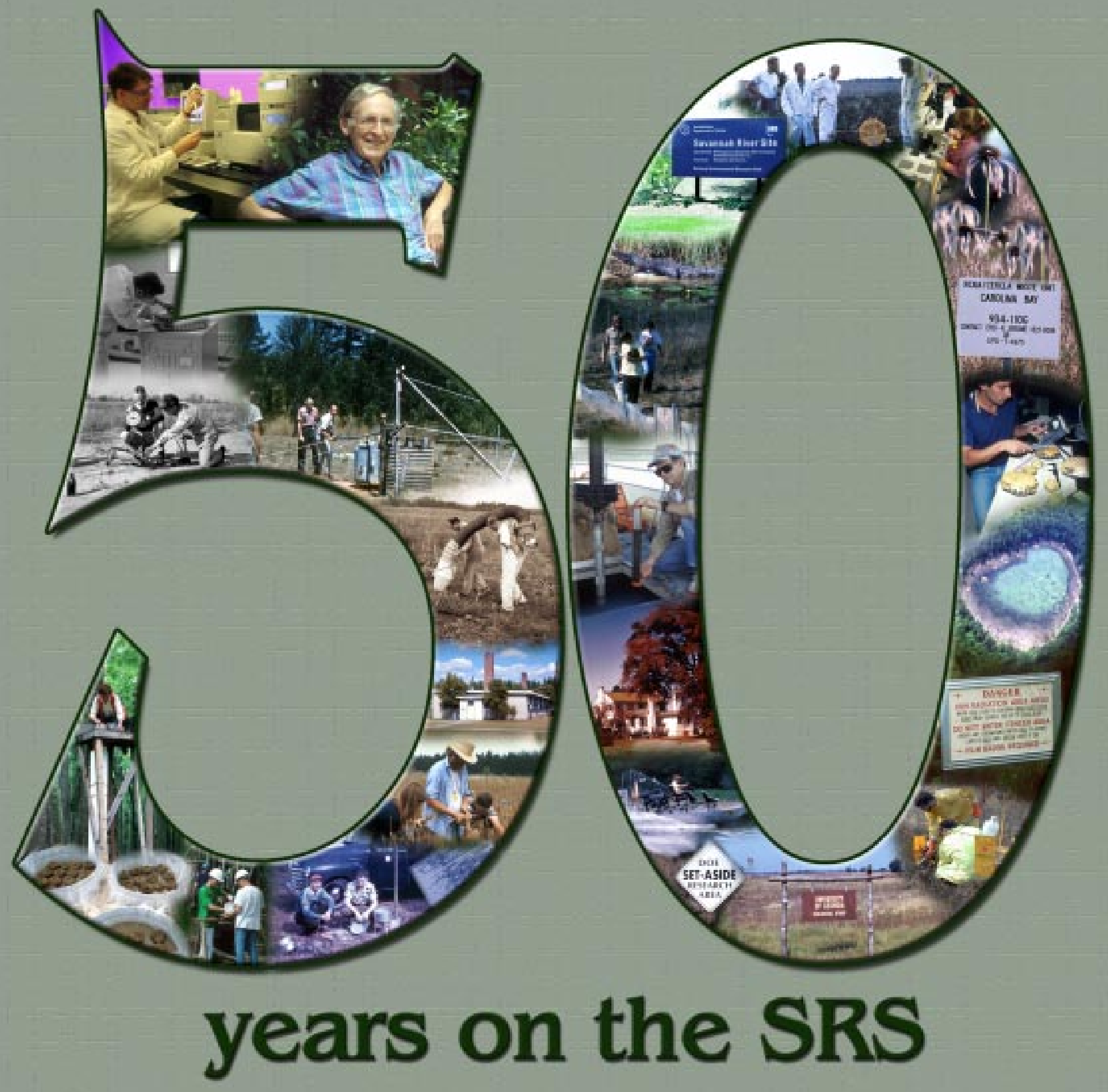

\title{
Savannah River Ecology Laboratory Annual Technical Progress Report 2002
}




\section{SaVAnNah River ECOLOGY LABORATORY}

\section{Annual Technical Progress Report of Ecological Research}

Draft submitted 1 July, 2002

Final submitted 17 July, 2002
Supported under Cooperative Agreement DE-FC09-96SR18546 between
The University of Georgia and the
U.S. Department of Energy for

The University of Georgia fiscal year ending June 30, 2002

Paul M. Bertsch, Director

Prepared by Laura Janecek

Savannah River Ecology Laboratory Drawer $\mathrm{E}$ Aiken, SC 29802

PH (803) 725-2472 FX 725-3309 E-mail: Janecek@srel.edu www.uga.edu/srel/ 
This report is provided for information only and is not to be considered formally published literature. We request that no citations be made of information contained herein without the express consent of the investigator. 


\section{TABle of Contents}

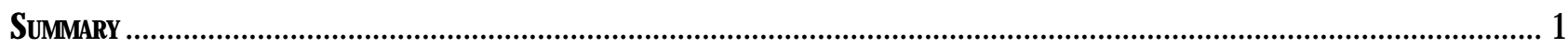

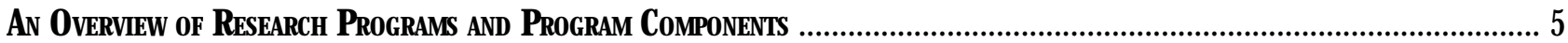

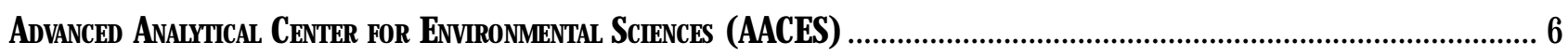

Analytical Applications and Technology Development for the Characterization of Complex Wasteforms

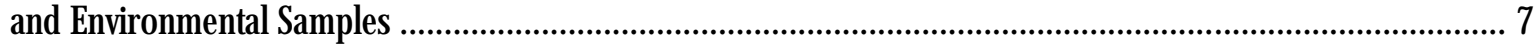

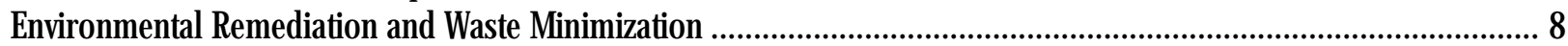

Environmental Chemistry and Transport of Contaminants Through Ecosystems ..................................................10

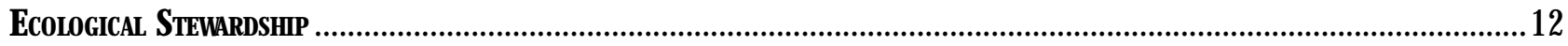

Impact of SRS Clean-Up on the Biological and Functional Diversity of Aquatic Bacteria ........................................13

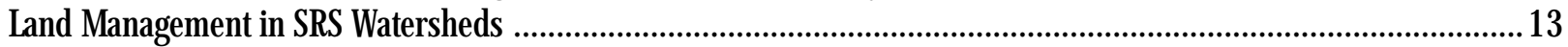

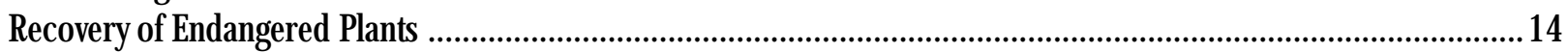

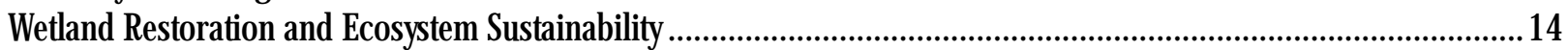

Research on the Spatial Distributions of Biotic and Abiotic Features of Savannah River Site Reservoirs ................... 16

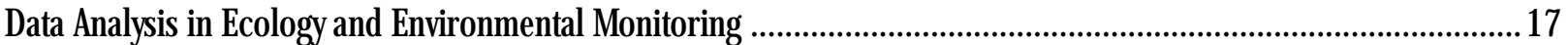

Research on SRS Herpetofauna for Application to Monitored Natural Attenuation Studies, Assessing the

Distribution of Sensitive Species, and Examining Biodiversity Patterns on a Protected Site .............................. 17

Restoration Ecology of Highly Impacted Forested Floodplain Ecosystems .......................................................... 18

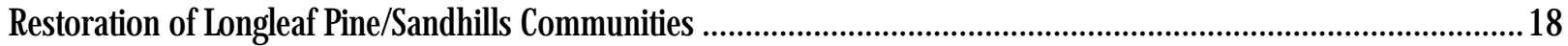

Phytoremediation of Contaminants in Constructed and Natural Wetlands ...........................................................19

History of Environmental Change on the Savannah River Site ........................................................................20

Ecotoxicology, RemEdiation, AND Risk AsSESSMENT (ETRRA) _................................................................................. 22

Cycling of Mercury in SRS Waters and Accumulation by Fish and Wildlife; Effects of Heavy Metals on Biota .............. 23

Monitoring and Risk Assessment for the Endangered Wood Stork ........................................................................24

Ecotoxicology: Environmental Physiology of Sublethal Effects of Trace Element Contamination on

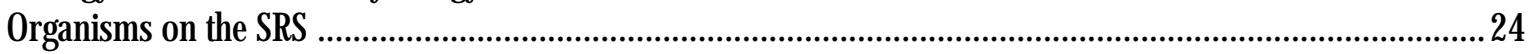

Risk Assessment of Mixed Waste: Synergistic Effects on Individuals and Populations .............................................25

Studies of the Fate and Effects of Nuclear Industrial Contaminants in Wildlife of the Savannah River Site:

Assessments of Ecological and Human Health Risks ............................................................................... 26

Phytoremediation and Enhanced Monitored Natural Attenuation: Plant-Based Technologies to

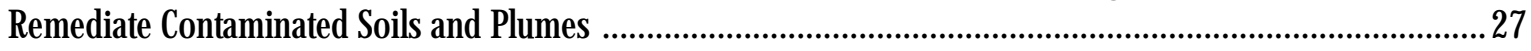

Aquatic Invertebrates and Trophic Pathways for Contaminants in Pond 4, a Small Abandoned Cooling

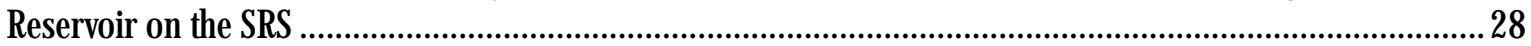

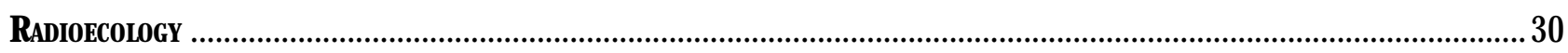

Environmental Distribution, Uptake, and Transport of Radioactive Contaminants on the Savannah

River Site: Meeting DOE Needs for Compliance and Predictions of Risk .................................................... 31

Dose Assessments for Plants and Animals Exposed to Environmental Radiation .................................................... 32

Genetic Changes in Response to Previous and Current Plant Operations ........................................................... 33

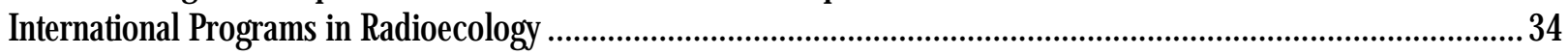




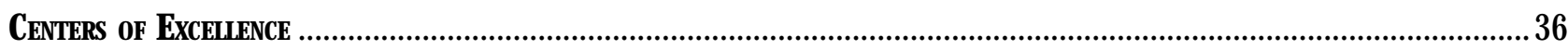

Experimental Approach to Constructed Treatment Wetland Design........................................................................37

A Field Test of the Efficiency of a Biotic System for Remediating Radionuclide and Metal Contamination in Surface Waters .........................................................................................................

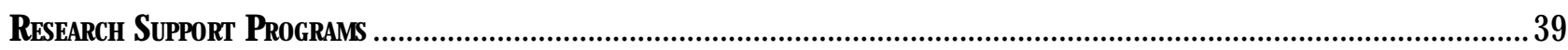

National Environmental Research Park Program ................................................................................................4 40

Environmental Health and Safety Program .................................................................................................. 40

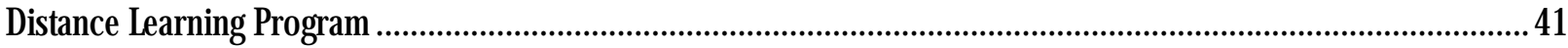

Quality Assurance Program ...................................................................................................................... 42

Research Data Archive Activities ................................................................................................................... 42

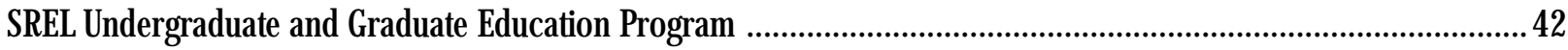

Environmental Outreach and Education ......................................................................................................4

DOE Research Set-Aside Areas ..................................................................................................................... 46

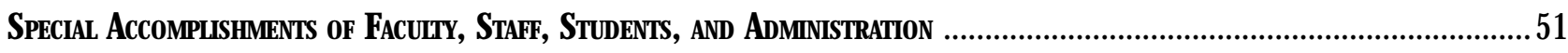

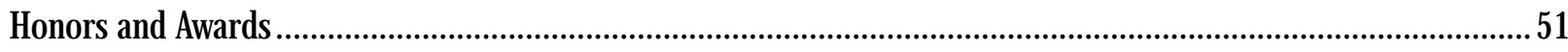

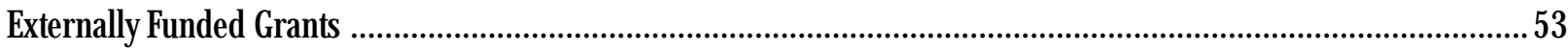

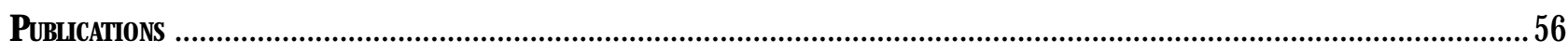

Journal Articles and Book Chapters Published ................................................................................................56

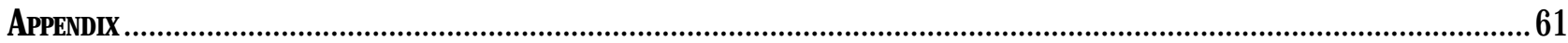

Figure 1. Organizational Chart for the Savannah River Ecology Laboratory .............................................................61 


\section{Origin}

The Savannah River Ecology Laboratory (SREL) was founded in 1951 by Dr. Eugene P. Odum of The University of Georgia, who began ecological baseline studies on the Savannah River Site with financial support from the Atomic Energy Commission. Throughout its history, SREL has been operated by The University of Georgia.

\section{Mission}

The Savannah River Ecology Laboratory's mission, as defined in its Cooperative Agreement with the U.S. Department of Energy (DOE), is to provide an independent evaluation of the ecological effects of Savannah River Site (SRS) operations through a program of ecological research, education, and outreach. This program involves basic and applied environmental research, with emphasis upon expanding the understanding of ecological processes and principles, and upon evaluating the impacts of industrial and land use activities on the environment.

This mission is accomplished through a broad-based program of field and laboratory research conducted on the SRS and published in the peer-reviewed scientific literature; by providing education and research training for undergraduate and graduate students from colleges and universities throughout the United States and abroad; and by engaging in community outreach activities and service to professional organizations.

\section{Funding}

The Savannah River Ecology Laboratory's primary funding source is a Cooperative Agreement between the U.S. Department of Energy and The University of Georgia Research Foundation that covers a five-year period from July 1, 2001 through June 30,2006 . The estimated total cost of this agreement is almost $\$ 53$ million, with DOE contributing about $\$ 50$ million and the University of Georgia about \$3 million. Additional funding, about \$1.6 million in FY02, comes from other contracts and grants involving a variety of other organizations. SREL's total operating budgets from DOE in FY99, FY00, FY01, and FY02 were $\$ 10.3, \$ 8.9, \$ 9.7$, and $\$ 10.2$ million, respectively; the FY03 budget is projected to be $\$ 9.0$ million. SREL also receives almost $\$ 700,000$ per year from The University of Georgia. During FY02 an additional $\$ 800,000$ was received from DOE and WSRC for SRS-related research and outreach.

\section{Staffing}

The Savannah River Ecology Laboratory currently has a staff of about 150 people, most of whom are employees of The University of Georgia. The staff includes 20 faculty, six of whom are co-staffed through tenure-track positions in various departments at The University of Georgia and one who is co-staffed through a tenure-track position in the School of Public Health of the University of South Carolina. There are another $10 \mathrm{Ph} . D . s$ in other technical positions or postdoctoral appointments. Research technicians ( 54), clerical and other support personnel (40), and graduate students (26) comprise the remaining staff categories.

\section{Organizational Structure}

The Savannah River Ecology Laboratory is a research unit of The University of Georgia, and its Director reports to the UGA Vice President for Research. At the Savannah River Site, SREL and its Director report to the DOE Assistant Manager for Environmental Programs, Science and Technology. Internally, SREL is organized into four research groups, an outreach program, and support services. 


\section{Facilities}

The Savannah River Ecology Laboratory's main facility consists of a 45,000- $\mathrm{ft}^{2}$ building with offices, general and specialized laboratories (e.g., molecular, GIS, analytical instrumentation), meeting rooms, a computer center, and a library. Additional buildings and research facilities surround the main lab, including a distance learning facility, greenhouse complex, rhizotron/ lysimeter, animal holding buildings, and a maintenance shop. A5,000- $\mathrm{ft}^{2}$ laboratory and additional offices are located in BArea, about 5 miles from the main lab, and a 3,500- $\mathrm{ft}^{2}$ radioecology laboratory is located at Par Pond, about 15 miles from the main lab. A 5,000- $\mathrm{At}^{2}$ conference center was built by The University of Georgia on SRS land leased to the University.

Additional information about SREL can be found on the laboratory's Internet web site: http://www.uga.edu/srel/ 


\section{Savannah River Ecology Laboratory Mission Focus}

\section{Safety and Security}

- DOE approval of the Necessary and Sufficientprocess to ensure the safety and health of SREL employees by adopting work-smart safety and environmental standards.

- ISO 14001 certified.

\section{Technical Capability}

- Four research groups with more than 25 program elements:

- Advanced Analytical Center for Environmental Sciences

․ Ecological Stewardship

Ecotoxicology, Remediation, and Risk Assessment

Radioecology

- Publication of 76 journal articles, with an additional 50 articles submitted or in press.

- Funding for 22 grants totaling $\$ 1.6 \mathrm{M}$ in FY02.

- Faculty positions in 9 University of Georgia departments and adjunct faculty positions at 19 other universities and research institutions.

- Service on over 65 editorial boards/committees.

- Presentation of more than 100 scientific presentations and lectures.

- Eighteen undergraduate and 42 graduate students conducting research.

- SREL students were awarded 3 masters and 4 doctorate degrees in FY02.

- In the last year, SREL sponsored 4 co-op students from local universities in its Computer Services Group.

- SREL personnel include 30 Ph.D. level scientists with 54 supporting technicians.

- The Laboratory continues to maintain state-of-the-art analytical capabilities.

- FT-Raman and FT-IR instrumentation was used to characterize the inorganic and organic components of biomineralized tissue generated by organisms living in contaminated environments on the SRS and elsewhere. Samples were also analyzed for their carbon and oxygen stable isotope composition to determine the timing of exposure and the acquisition of contaminants in various tissue compartments.

- SREL researchers have demonstrated that hydroxylapatite, a typical phosphate-containing fertilizer amendment, will immobilize metals such as uranium, nickel, copper, chromium, aluminum, and lead in sediments with minimal ecological disturbance. Studies have also demonstrated that chemical immobilization of the metal contaminants is accompanied by reduced bioavailability to microorganisms.

- Collaborative studies with researchers at the Medical University of South Carolina have demonstrated that Ni in the Steed Pond system is toxic to a variety of microorganisms, including sulfate reducing bacteria and those responsible for degrading TCE.

- Bald cypress continue to show a greater overall ability to tolerate fly ash associated stresses in experimental plantings at the F-Area seepline. Since outplanted into the D-Area ash basin in February, bald cypress seedlings have a 88\% survival rate, compared to $29 \%$ for water tupelo; however, while the seedlings have survived, growth is minimal.

- Tissues from juvenile snowy egrets that were exposed to low or elevated mercury concentrations in their diets were analyzed for stable nitrogen isotopes, providing a novel method of assessing protein turnover and allocation of dietary resources in stressed and unstressed animals. Egrets fed the higher mercury diet had higher $\delta{ }^{15} \mathrm{Nratios}$ in their livers than those fed the low mercury diet. This suggests enhanced rates of protein degradation and synthesis in response to mercury exposure, as well as increased metabolic costs.

- Green frog larvae raised on coal fly ash accumulate concentrations of Se and As that are more than an order of magnitude higher than levels in control larvae. Ash-exposed larvae also exhibit reduced growth rates, protracted 
larval development, and reduced survival through metamorphosis.

- Studies of nickel, cadmium, and zinc uptake have been completed for a wide range of hybrid poplars (Populus spp.), concentrating on those that have been used previously for phytodegradation of trichloroethylene (TCE). Considerable clonal differences have been shown between clones within the same species, and there is evidence to suggest that their different tolerance abilities may allow them to either facilitate or prevent phytoextraction to meet the needs of the end user.

- Studies modeling natural attenuation and contaminant bioavailability at Steed Pond indicate that uranium, the main contaminant of concern, is not accumulating within plant tissues and herbivores, but data strongly suggest that there is considerable migration of $\mathrm{Ni}$.

- A technique for the in situ remediation of ${ }^{137} \mathrm{Cs}$-contaminated wetlands was field-tested in Pond $A$ and the Rdischarge canal on the SRS. Replicated limnocorrals were deployed as experimental units and two treatments of illite clay, plus a control, are being used to evaluate the remediation method.

- Amolecular marker has been successfully developed for assaying the frequency of environmental radiation-induced chromosome damage in turtles.

\section{Community, State, and Regulator Relationships}

- In October 2001, a workshop led by Drs. Newman and Adriano on natural remediation processes convened at the UGA Conference Center. Over 100 participants from the region included members of the regulatory community as well as scientists from SRS.

- SREL celebrated its $50^{\text {th }}$ Anniversary by convening a symposium entitled "The Savannah River Ecology Laboratory: 50 Years of Environmental Research," at which former and current SREL scientists spoke about the history of research at the Laboratory. A "Family Day" picnic was held for former and current SREL staff and their families to commemorate the anniversary.

- The SREL Outreach Program reached the general public through more than 430 events in an attempt to improve scientific literacy.

- The third printing of a publication from the Savannah River Ecology Laboratory entitled Snakes of Georgia and South Carolina provides information on identifying and understanding the 40 species of snakes in Georgia and the 38 in South Carolina. The lab partnered with 19 organizations in the third printing of this publication.

- SREL personnel continue to interact with SRS, SCDHEC, and EPA personnel in the Integrated Operable Unit program within Westinghouse Savannah River Company Environmental Restoration Division.

\section{Cost Effectiveness}

- SREL's overhead rate is among the lowest in the DOE complex.

- SREL continues to replace General Services Administration vehicles with lower cost University of Georgia vehicles.

- UGA returns nearly $\$ 700,000$ to DOE as faculty salaries, new vehicles, foreign travel, and capital equipment. This amount is nearly equal to SREL indirect charges.

- UGA operates SREL on a nonprofit basis.

\section{A Corporate Perspective}

- SREL participates in joint research proposals and projects with National Laboratories, other DOE sites, and universities.

- SREL faculty and staff participate in national DOE review committees (WIPP, EMSP, SERDP).

- The Distance Learning Facility provided nearly 300 hours of academic and non-academic programming to SRS personnel. The Distance Learning Program offers a graduate degree in Environmental Toxicology from The University of Georgia.

- SREL personnel continue to participate in the site-wide environmental committees of the Natural Resources Coordinating Committee and the U.S. Forest Service-SR ID team. 


\section{SUMMARY}

The Savannah River Ecology Laboratory ( SREL) is a research unit of The University of Georgia (UGA) and has been conducting ecological research on the Savannah River Site (SRS) near Aiken, South Carolina for 50 years. The overall mission of the Laboratory is to acquire and communicate knowledge of ecological processes and principles. SREL conducts fundamental and applied ecological research, as well as education and outreach programs, under a Cooperative Agreement with the U.S. Department of Energy (DOE) .

The Laboratory's research mission during the 2002 fiscal year was fulfilled with the publication of 76 journal articles and book chapters by faculty, technical staff, students, and visiting scientists. An additional 50 journal articles have been submitted or are in press. Other noteworthy events took place as faculty members, staff, and graduate students received awards. These are described in the section titled Special Accomplishments of Faculty, Staff, Students, and Administration on page 51.

Notable scientific accomplishments include work conducted on contaminant transport, stable isotopes, sandhills ecology, and phytoremediation.

- A collaborative study between Dr. Tom Hinton at SREL and scientists at SRTC demonstrated the feasibility of using illite clay to sequester ${ }^{137} \mathrm{Cs}$ in sediments along the $\mathrm{P}$ and R reactor cooling canal system, where approximately 3,000 acres of land are contaminated. Overall, the study showed significant decreases in cesium concentrations and bioavailability following the addition of illite with no sign of harm to the ecosystem. While the cesium remains sequestered from the biosphere, its radioactivity decays and the process progresses from contaminant immobilization to remediation.

- SREL's stable isotope laboratory is now fully functional. Stable isotope distributions in nature can provide important insights into many historical and current environmental processes. Dr. Christopher Romanek is leading SREL's research in this area, which focuses on identifying the sources and fate of environmental contaminants and on identifying historical patterns of environmental change.

- Dr. Beverly Collins is a coauthor of a report published by the U.S. Army Corps of Engineers on a workshop that was held at SREL in March 2001 on sandhills ecology and ecosystem management. The workshop, sponsored by the Strategic Environmental Research and Development Program (SERDP), brought together scientists and land managers from throughout the Southeast. SREL currently has two SERDP-funded projects, including one that was awarded in 2002.

- A cooperative, multidisciplinary study was initiated with the U.S. Forest Service and Environmental Restoration in the 488-D ash basin on the SRS. This work involves the use of a vegetative cover and common soil additives to mitigate the high acidity and salinity resulting from the oxidation of pyrite in the coal refuse piles. Coal combustion residues from electrical power facilities constitute a major source of solid waste at many DOE and commercial sites.

SREL's research was enhanced this year by the addition of three new faculty members. Dr. Machelle Wilson, who specializes in data analysis for ecology and environmental monitoring, joined SREL in October 2001. Dr. Steven Harper, a GIS/remote sensing specialist who will conduct research on the spatial distributions of biotic and abiotic features of SRS habitats, joined the lab in January 2002. In an effort to further diversify the faculty and also to take advantage of research areas that promise to offer funding opportunities in the near future, the laboratory issued a call for proposals for "junior faculty" positions, wherein a junior faculty member will work closely with one or more senior faculty mentors on a research project for three years, after which the SREL faculty will judge the individual's professional progress and determine whether they should be retained in a faculty position. During FY02, three research proposals were submitted and subjected to peer review by scientists from outside SREL. As a result of this process, SREL hired Dr. William Hopkins into the Lab's first junior faculty 
position. Dr. Hopkins will study the effects of selenium and other contaminants on the physiology and behavior of reptiles and amphibians. During the past year SREL also advertised for an additional faculty position in the area of environmental microbiology. Because a number of highly qualified applicants applied for this new position, SREL is fortunate to have retained two new faculty members in this field, both of whom will begin work at SREL during late summer, 2002.

Researchers at SREL currently have funding totaling $\$ 1.6 \mathrm{M}$ from 22 grants in addition to funds provided by DOE-SR. Sources of grant awards range from private agencies such as the U.S. Golf Association to federal agencies such as the U.S. Environmental Protection Agency, the National Science Foundation, and the Department of Defense (DoD). Important grants received this year included an award of $\$ 939,523$ over four years to Dr. Rebecca Sharitz and colleagues from DoD's Strategic Environmental Research and Development Program ( SERDP) , to study impacts of military training and land management on threatened and endangered species in the southeastern fall line/sandhills community, \$100,000 to Dr. Paul Bertsch from the U.S. Environmental Protection Agency to study the effects of compounds and colloids on partition coefficients for radionuclides and other inorganic compounds, and $\$ 64,000$ to Dr. Charles Jagoe for a renewal of SREL's Research Experiences for Undergraduates grant from the National Science Foundation. An additional $\$ 800,000 \mathrm{M}$ was received from DOE and WSRC for SRS-related research and outreach activities.

This year the Savannah River Ecology Laboratory celebrated its 50th anniversary on the SRS with a number of events during the week of 14-20 October 2001. Augusta Mayor Bob Young proclaimed that week "In Recognition of the Savannah River Ecology Laboratory" week, and UGA President Michael Adams also issued a University proclamation congratulating SREL on the long record of stellar performance by the Laboratory and recognizing SREL's important contributions to UGA. An "employee appreciation day" for current and former SREL employees and their families was held at the SREL Conference Center. Lunch was provided, games were available for young and old, and a good time was had by all. A 50th Anniversary Commemoration and media day had also been planned, but this event had to be canceled due to increased security on the SRS after the events of 9-11. The anniversary week concluded with a day-long symposium entitled "The Savannah River Ecology Laboratory: 50 Years of Environmental Research," held at the Conference Center. Seven former SREL staff and students were invited to give presentations on topics ranging from SREL's long history of research on secondary succession to its pastand currentresearch in radioecology. Symposium speakers included Drs. John Pinder, Ray Semlitsch, John Avise, Peter Stangel, James Spotila, John Giesy, and Ward Whicker. Three of SREL's former Directors were also in attendance and each gave a short address. The symposium concluded with a reception and dinner buffet. The anniversary week concluded on Saturday with field trips to several of SREL's historic research sites, including Rainbow Bay, Ellenton Bay, and Field 3-412.

SREL's maintenance program underwentan external review in August 2001 from the Association of Higher Education Facilities Officers. The main purposes of the review were to assess whether SREL's maintenance program is configured appropriately in terms of personnel (numbers, expertise, organization) and resources, and to assess the overall maintenance program and identify those elements that are functioning well and those where improvements can be made. The review evaluated SREL's program againsta number of established benchmarks in areas such as leadership, strategic and operational planning, customer satisfaction, development and management of human resources, process management, and performance results. The results of the review were very positive, and a number of recommendations from the committee are currently being implemented. The committee also noted that the maintenance group provides many services to SREL that go far beyond the normal definition of maintenance. The committee's inal report stated that "SREL is fortunate to have a maintenance staff that is very well-qualified to serve the research staff. They perform a vast array of important work for the laboratory."

During the past year SREL has continued to make progress toward achieving the objectives outlined in the Laboratory's strategic plan. The Laboratory's Research Manager tracks the objectives and strategies detailed in the plan and the ad hoc Strategic Planning Committee assembles twice each year to assess institutional progress. In an effort to bring strategic planning into all aspects of SREL operations, the various support groups in the Laboratory drafted strategic plans for their units. Computer Services, Facility Maintenance, Administrative Services, the GIS Laboratory, and Safety Services have completed 
strategic plans for their units that tie directly into the lab-wide plan. Each of these groups developed a group mission statement and group strategic goals, objectives, and strategies by which their annual progress can be tracked. The GIS Lab plan, in particular, was written to enhance integration and coordination with the Computer Services group, eliminating duplication where possible and maximizing personnel and equipment resources. All of these plans are posted on SREL's intranet website along with the SREL Strategic Plan so that all Laboratory personnel have access to this information and can see how each unit is integral to achievement of the lab-wide strategic goals. During FY02 SREL made significant progress toward achieving two objectives of the Lab's strategic plan related to acquiring new funding solutions for SREL research programs. The Laboratory's objectives are (1) to increase the level of outside funding received to at least \$2M annually by FY05- \$1.6M was received in FY02; and (2) to seek at least \$750,000 annually in SRS site-specific task funding by FY05$\$ 800,000$ was received during FY02.

During FY02 SREL purchased about $\$ 250,000$ worth of major equipmentitems to keep the Laboratory on the cutting edge of ecological and environmental science. Almost $\$ 90,000$ of this amount came from The University of Georgia, and the remainder from DOE. In addition to replacing some existing equipment, funds were used to purchase a multi-element X-ray detector and hydroacoustics remote sensing equipment.

Participants in the SREL Education Program during FY02 came from schools located throughout the United States and included 18 undergraduate students and 42 graduate students. The graduate students came from nine different universities in the U.S. and abroad, emphasizing the national and international stature of the SREL program. In the past year three graduate students from SREL earned Masters Degrees and four earned Doctor of Philosophy Degrees. A National Science Foundation grant from the Research Experiences for Undergraduates Program for a proposal titled "The Impact of Energy Technologies on Natural Environmental Systems" continued to provide funding for the undergraduate program at SREL.

In addition to holding faculty positions in nine departments at the University of Georgia, various SREL faculty have adjunct status at 19 other colleges and universities. Faculty, staff, and students also are active in providing outreach and service to the scientific community. Representatives from the SREL hold more than 65 editorial or committee positions in national groups and organizations and also serve on several UGA academic and administrative committees. Over 100 lectures, scientific presentations, and posters were presented during the past year at scientific meetings, colleges, and universities, including minority institutions.

The SREL Outreach Program reaches a different audience in its efforts to communicate scientific awareness to the general public. During the pastyear, SRELscheduled 320 talks, 30 tours, 27 exhibits, and 53 workshops, for a total of 41,871 people reached. Topics of these presentations included biodiversity, the process of science, animal adaptation, plants and wetlands, environmental science and chemistry, local ecosystems and conservation, classification, and careers in ecology and research. A book produced by the SREL Outreach Program, The Snakes of Georgia and South Carolina, originally released to the public in May 1998, has been so well received that the third printing is almost sold out. Other educational products produced during the past year included a flier on Carnivorous Plants and Their Habitats and an emergency services calendar that depicts animals, plants, and habitats of the SRS, produced in cooperation with Westinghouse Savannah River Company. Aflier on An Amphibian's Eye View of Wetlands was so popular that it was reprinted during the past year, with sponsorship from the Peace Frogs clothing company. As part of a new outreach initiative in chemistry and environmental science, a large sticker with the slogan "Chemistry - it's all about the nature of things" was produced and is given to all students who participate in the classroom and workshop programs in this new subject area. Other popular SREL products that were reprinted during the past year included the children's comic book Stepping into Ecology: the Ecological Adventures of Muddy Boot, produced in cooperation with the Medical University of South Carolina's Environmental Bioscience Program, and a flier on Is it a Water Moccasin?, produced in partnership with the Georgia Department of Natural Resources. All of these products have been extremely popular and thousands of copies have been distributed during the past year. 
In conjunction with SREL's 50th anniversary celebration, SREL Director Paul Bertsch launched the "Savannah River Ecology Laboratory Endowment Fund for Environmental Outreach and Education." Donations to this fund, which has an initial goal of $\$ 5 \mathrm{M}$, will be used to expand and enhance the Laboratory's existing Environmental Outreach Program.

The SREL Distance Learning Program continued to focus its efforts on programming related to the Laboratory's core programs in ecology and environmental science. SREL, in cooperation with and with funding from the UGA College of Pharmacy, is offering a multidisciplinary Master's Degree in Environmental Toxicology via the Georgia Statewide Academic and Medical Systems (GSAMS) network. This is the first degree offered by UGA through any distance learning site in Georgia or South Carolina. Five new students are expected to begin the program in the fall of 2002, in addition to five students continuing into the second year of coursework for the degree. Three students have completed all required coursework and are working on the research component of the degree. In an effort to expand their audience, the SREL Outreach Program presented 14 Ecotalks via distance learning to elementary, middle, and high school students in both South Carolina and Georgia. This approach allows Outreach staff to reduce animal handling and transport time and reach multiple schools simultaneously.

The Conference Center has continued to see wide use, both by SREL personnel and the local community. The facility was used to host a total of 75 scientific meetings and environmental education programs for students, teachers, and the general public this pastyear, and 2,500 people visited the facility. Funding is being sought to constructa Nature Center for outreach activities at the Conference Center site.

Representatives of the Laboratory also serve local and statewide communities by organizing a canned goods drive in November, managing a recycling program, participating generously in the UGA Campaign for Charities, and hosting an annual auction benefiting the South Carolina Chapter of The Nature Conservancy. 


\section{An Overview of Research Programs}

\section{and Program Components}

Research at the Savannah River Ecology Laboratory is conducted within the framework of four research groups. While research is conducted within this framework, it is not restricted by it. Multidisciplinary and multi-investigator driven research projects are encouraged. More detailed information about each research group and its individual projects follows.

The four research groups are:

$\square \quad$ Advanced Analytical Center for Environmental Sciences (AACES)

$\square \quad$ Ecological Stewardship

$\square \quad$ Ecotoxicology, Remediation, and Risk Assessment (ETRRA)

$\square$ Radioecology 


\section{Advanced Analytical Center for EnVIRONMENTAL Sciences (AACES)}

Advanced analytical and spectroscopic techniques provide an opportunity to generate new scientific knowledge needed for solving complex environmental problems, as well as developing cost-effective remediation strategies. Application of these advanced methods can provide scientifically defensible data to support risk assessment-based remediation strategies that involve in situ stabilization or no remedial action, both of which should significantly reduce costs. Included in the diverse array of advanced instrumentation being applied to analyze complex environmental samples and elucidate fundamental processes are: synchrotron X-ray absorption spectroscopy, ion cyclotron resonance mass spectrometry, isotope ratio mass spectrometry, inductively coupled plasma mass spectrometry and optical emission spectroscopy, atomic force microscopy, FT-Raman and FT-IR spectroscopies, X-ray diffraction and solid-state tunable laser spectroscopy.

AACES is organized around three interactive research programs in:

․ Analytical Applications and Technology Development for the Characterization of Complex Wasteforms and Environmental Samples

ㅁ Environmental Chemistry and Transport of Contaminants through Ecosystems

Environmental Remediation and Waste Minimization

AACES objectives are to:

․ Serve as an advanced research and development facility with a primary interest in bridging basic and applied environmental research from the molecular to landscape level;

口 Acquire and develop the infrastructure to provide local, regional and national users from industry, government, and universities with both the expertise and advanced methods required to generate a better understanding of contaminant behavior in the environment, elucidate molecular mechanisms of toxicity, and develop better, cheaper and more environmentally sound remediation approaches; and

․ Providea mechanism for the further development, modification, and application of advanced analytical and spectroscopic techniques to better understand complex environmental processes. 


\section{Analytical Applications and Technology Development for the Characterization of Complex Wasteforms and Environmental Samples}

Principal Investigators: Paul M. Bertsch, Brian P. Jackson, Gary L. Mills, Christopher S. Romanek, and John C. Seaman

The remediation and restoration of contaminated sites throughout the U.S. Department of Energy (DOE) weapons complex present formidable problems due to the diversity and complexity of both the waste mixtures and subsurface environmental matrices. Scientifically sound characterization, remediation, and performance assessment technologies that are cost-effective and provide acceptable risks to humans and ecosystems are needed to achieve regulatory objectives and to fulfill DOE's waste management and cleanup goals. The successful development and implementation of these technologies require knowledge of the chemical speciation, spatial distribution, reactivity, transformation reactions, geochemical mobility, and bioavailability of contaminants at the atomic and molecular scales that can be used to interpret and predict contaminant behavior at microscopic, macroscopic, and field scales. The various research programs within the Advanced Analytical Center for Environmental Sciences (AACES) address these issues by employing an integrated, multidisciplinary, multiscale approach to studies at the interface between basic and applied environmental research. The Analytical Applications and Technology Development Program, which focuses on the development and application of advanced analytical techniques for the molecular scale characterization of complex wasteforms and environmental samples, is a cornerstone component of the research efforts within AACES. Using an array of "state-ofthe-science" analytical instruments and technologies, the program develops and applies novel and innovative methods to acquire the molecular scale measurements that are prerequisite to conducting studies within this program and other programs at SREL.

- Developmentand deployment of Micro-XAFS and microdiffraction techniques continue at the hard X-raymicroprobe, X26A, at the National Synchrotron Light Source at Brookhaven National Laboratory. These techniques are being coupled with micro-XRF analyses to provide detailed information on the distribution and chemical speciation of radionuclides, metals, and metalloids in soils, biota, and wasteforms. The recent successful installation of a new liquid cooled Si (111) monochromator crystal (and tank) has greatly enhanced the optics of the beamline with an enhanced flux, energy range (4.8-22 KeV), and outstanding energy resolution improvement. A liquid-cooled Si (311) crystal is scheduled to be installed later this year, which will greatly improve energy resolution for XAFS and extend the energy range up to about $40 \mathrm{KeV}$. ACanberra 13 element Ge array detector was designed and is currently being constructed. We expect that it will be completed and installed later this year, further enhancing the capabilities of the beamline.

- High-resolution gas chromatography and gas chromatography-mass spectrometry were used to perform congener specific analysis of polychlorinated biphenyls (PCBs) in clapper rail hatchlings collected from a EPA Superfund site as part of a project funded by the U.S. Fish and Wildlife Service.

- ATekmar Solatec 72 volatile organic compound (VOC) sampling/concentration system was acquired and interfaced to a gas chromatograph- mass spectrometer. This system enhances the detection limits for determining VOCs and provides automated analysis of water, soil, and plant tissue, greatly improving sample throughput.

- The operating system and software were upgraded for the Fourier transform-ion cyclotron resonance-mass spectrometer (FT-ICR-MS). The MSWindows-based OS will facilitate use of the high-resolution MS by researchers by providing a familiar operating platform and data file structure.

- An isotope ratio mass spectrometer (IRMS) was used to characterize the source and pathways of hydrogen and carbon incorporated in the biomass of the dissimilatory iron reducing bacteria Shewanella putrifaciens and algae. These data were used to infer the predominant mode(s) of microbial growth in soil and sediment collected from field samples at the SRS and elsewhere.

- FT-Raman and FT-IR instrumentation was used to characterize the inorganic and organic components of biomineralized tissue generated by organisms living in contaminated environments on the SRS and elsewhere. Samples were also analyzed for their carbon and oxygen stable isotope composition to determine the timing of exposure and the acquisition of contaminants in various tissue compartments. 
- A new acoustic spectrometer (Dispersion Technology DT 1200) was purchased and installed to enable us to evaluate the particle size and zeta potential (i.e., particle surface charged) of concentrated ( $>1 \%$ solids) colloidal suspensions. The ability to stir the suspension during acoustic analysis makes it possible to evaluate aggregation and charging phenomena of inherently unstable suspensions or during key surface-chemical transitions, i.e., the point of zero charge.

- Afield study in collaboration with Clark Atlanta University (Dr. Sunnie Aburime), the Westinghouse-Savannah River Technology Center ( Drs. Looney and Rosabi), and the Savannah River Forest Service ( Drs. Blake and Barton) has demonstrated the superiority of vapor extraction wells when compared to suction lysimeters for monitoring tritium migration in the vadose zone.

- A laser ablation system was commissioned to be interfaced with the ICP-MS. This instrumentation will allow for direct solid sampling utilizing ICP-MS as a detector. The resulting coupled technique will allow for spatial analysis of samples and will be complementary to synchrotron XAS studies.

- Size exclusion chromatography and anion exchange chromatography were interfaced with ICP-MS to study Se speciation in extracts of fish tissue from a fish caught at the D-Area ash basin, which contains multiple contaminants including As and Se.

- Synchrotron X-ray absorption spectroscopy, including XAS elemental mapping and extended X-ray absorption fine structure (EXAFS) studies were used to determine the spatial variability and speciation of Se in tadpoles exposed to coal fly ash.

- Sedimentation field flow fractionation was interfaced with ICP-MS to study the association of $\mathrm{Pb}$ with water dispersible colloids from contaminated soils. This instrumental technique allowed for the determination of the particle size distribution of the colloidal suspension and an element-based size distribution.

\section{Environmental Remediation and Waste Minimization}

Principal Investigators: DomyC. Adriano, Paul M. Bertsch, Gary L. Mills, Christopher S. Romanek, John C. Seaman, and Brian P. Jackson

The operation of the DOE weapons complex over the past
$40+$ years has resulted in a diverse array of environmental problems that involve the chemical contamination of surficial and subsurface materials. These contaminants include both stable elements and radionuclides in a variety of inorganic and organic compounds, including reactive metals ( e.g., $\mathrm{Ni}$, $\mathrm{Al}, \mathrm{Cr}, \mathrm{Cu}, \mathrm{Cd}, \mathrm{Zn}, \mathrm{As}, \mathrm{U}, \mathrm{Cs}$ ), organometallic compounds (e.g., organo-Hg and -Se species), and organic chemicals (e.g., Light and Dense Non Aqueous Phase Liquids, halogenated hydrocarbons, fuel additives, polychlorinated biphenyls and polycyclic aromatic hydrocarbons). In addition, coal combustion residues (e.g., fly ash, flue gas desulfurization sludge) from electrical power facilities constitute a major source of solid waste at many DOE and commercial sites. Such contaminants can be found together in complex associations of mixed waste and pose significant human health and ecological risks.

These contaminants mustbe removed from the environment or transformed into benign substances through active or passive remediation efforts. Scientists participating in the Environmental Remediation and Waste Minimization Program at SREL focus interdisciplinary research efforts on the characterization of the source, state, and fate of environmental contaminants, the identification of processes and mechanisms of remediation, and the development of methods for waste minimization that reduce the cost of the cleanup at contaminated sites on the SRS and throughout the DOE complex.

- A treatability study, in cooperation with the USFS-SR (Forest Service) and ER (Environmental Restoration) was re-established in February 2001 in the 488 D-Area ash basin. This work involves the use of a vegetative cover (as a solar-driven pump) and non-invasive chemical treatments, using common and inexpensive ameliorants to mitigate the high acidity and salinity resulting from the oxidation of pyrite in the coal refuse particles. The major amendments included the use of topsoil, coal fly ash (on site), and biosolid compost to provide a more ecologically friendly growth substrate for inoculated one-year-old pine seedlings. Seedlings planted on the new plots that were not ripped previously (deep disking to $\sim 3^{\prime}$ ) had very high mortality rate, apparently due to dense soil structure that roots cannot easily penetrate. Seedlings are growing much better on plots amended with either the topsoil, fly ash, apatite, or biosolid. Mostrecent observations indicate that plant 
roots are developing well, penetrating deeper than the treatment zone.

- Sequential chemical extraction of metal-contaminated soils can be used to evaluate the potential efficacy of soil remediation techniques. It can also serve as an indicator of natural attenuation. In addition to modifying partition coefficients that include a bioavailable component, other indices, which include less labile contaminants, are proposed. These indices may have some potential in the risk assessment of high metalcontaminated soils. This technique has been compared with other bioavailability assays, including biological and physiological tests as a potential tool in risk assessment. Recently, this technique is being tested to help elucidate key rhizosphere processes in contaminated and treated soils.

- The Tim's Branch/Steed Pond system received more than 45 MT of uranium and large quantities of other metals, such as nickel, copper, chromium, aluminum, and lead as a result of SRS operations. We have demonstrated that hydroxylapatite, a typical phosphate-containing fertilizer amendment, will immobilize these metals in sediments with minimal ecological disturbance. Studies have also demonstrated that chemical immobilization of the metal contaminants is accompanied by reduced bioavailability to microorganisms as determined by the MetPlate $^{\mathrm{R}}$ assay and nematodes due to mitigation of $\mathrm{Ni}$ toxicity.

- Ongoing studies using synchrotron-based X-ray microanalysis coupled with wet chemical extraction techniques of metal and U contaminated soils are unraveling mechanisms controlling the sequestration of these contaminants on aging. A thorough understanding of these mechanisms, how they are impacted by changing geochemical conditions, and how they relate to bioaccumulation and trophic transfer will be required to implement MNA as an alternate remediation strategy.

- Batch and column studies have identified several possible obstacles to the effective use of phosphoruscontaining organics for the in situ immobilization of contaminants. In many cases the immobilizing agent may actually enhance migration of the target contaminant.

- Bench-scale column studies were conducted on waste material from a fly ash basin located on the SRS to determine the source and fate of acid leachate generated at this site. Various fluids were circulated through columns filled with waste to determine the kinetics of acid and dissolved metal generation. Results were incorporated in potential design options for remediation efforts to minimize the generation of acid leachate at this site.

- A variety of natural physical, chemical, and biological processes act to reduce the amount, toxicity, mobility, and concentration of contaminants in the environment. Monitored natural attenuation (MNA) makes use of these processes to clean up contaminated soils and groundwater to achieve acceptable levels of risk to human health and the environment. In collaboration with scientists from Westinghouse Savannah River Company, we are conducting a study evaluating the feasibility of MNA as a treatment option for trichloroethene (TCE) in a groundwater plume in CArea at the SRS. Field studies have shown that TCE degradation products (dichloroethene and vinyl chloride) are correlated with methanogenesis and iron reduction in anaerobic soils. Laboratory experiments have demonstrated only weak sorption of TCE in saturated floodplain soils adjacent to Four Mile Creek.

- Permeable reactive barriers have proven to be a viable alternative to traditional pump and treat systems for groundwater remediation. This technology involves construction of a treatment zone comprised of reactive material to facilitate degradation of ground water contaminants intercepted by the barrier. In-situ redox manipulation (ISRM) is one type of permeable barrier that has been tested as a treatment strategy with some success. We have evaluated the use of ISRM by treatment of SRS aquifer sediments with injection of sodium dithionite to create a reducing zone for the removal of TCE and chromium. Using laboratory experiments we have optimized the dithionite injection protocol to create an effective treatment barrier while minimizing the formation of colloids from the aquifer sediments. Subsequent studies have demonstrated nearly complete removal of chromium but only $40-60 \%$ removal of TCE. These results indicate that ISRM may by very effective for the treatment of chromium contaminated groundwater but would require additional components in a treatment train for the removal of TCE in sediments typical of the Southeastern Coastal Plain. 


\section{Environmental Chemistry and Transport of Contaminants through Ecosystems}

Principal Investigators: Paul M. Bertsch, Gary L Mills, Christopher S. Romanek, and John C. Seaman

The legacy of nuclear materials production and processing for the manufacture of nuclear weapons has resulted in significantquantities of contaminant metals, such as uranium, nickel, chromium, and copper, and lesser quantities of a number of longer lived radionuclides (i.e., ${ }^{90} \mathrm{Sr}$ and ${ }^{137} \mathrm{Cs}$ ) and transuranics, as well as a wide range of contaminant organics, beingintroduced into soils and sediments throughout the U.S. DOE complex. Chemical speciation and/or contaminant mineral-surface interactions are the primary parameters controlling transport, bioavailability, and toxicity of metals, metalloids, and radionuclides from waste forms and within the environment. The subsurface migration of contaminants and contaminant mixtures within complex heterogeneous geologic systems is also controlled byvarious reactive mineral and organic components.

A more complete understanding of chemical species distributions and transformations and of the importance of physicochemical, mineralogical, and biogeochemical controls is required to accurately predict contaminant migration, to evaluate environmental risk, and to design cost effective yet environmentally sound remediation strategies.

This research effort is designed to: (1) determine the chemical speciation of metals, metalloids, radionuclides, and contaminant organics in a range of waste forms and SRS environs by standard and novel wet chemical and advanced techniques; (2) evaluate the biogeochemical dynamics of these contaminants as influenced by natural processes and various chemical and biological remediation strategies; ( 3 ) perform detailed physicochemical characterization of the Coastal Plain soils and aquifer sediments on the SRS and identify critical mineral surface/contaminantinteractions; (4) determine static contaminant partitioning/extraction as a function of local solution conditions (i.e., groundwater chemistry, contamination events, etc.) and soil/aquifer mineralogy; and (5) conduct intermediate/field-scale dynamic transport studies, which are analogous to the kinetically controlled conditions experienced in the field, to identify the mechanisms controlling the natural attenuation of contaminants and the impact of various proposed remediation/reclamation strategies.

- Synchrotron-based X-ray microanalysis of thin sections prepared from aged contaminated soil and sediments from the Tim's Branch/Steed Pond system reveal different mechanisms and rates of sequestration of the co-contaminants $\mathrm{U}$ and $\mathrm{Ni}$ during long-term aging. Feoxide mineral phases are critical mechanisms controlling natural attenuation processes of $\mathrm{Ni}$ in sediment strata low, medium, and high in organic matter ( 1 to $14 \%)$, whereas $\mathrm{U}$ is typically partitioned to detritus and organic rich regions that are spatially separated from regions of $\mathrm{Ni}$ accumulation.

- Collaborative studies with researchers at the Medical University of South Carolina have demonstrated that $\mathrm{Ni}$ in the Steed Pond system is toxic to a variety of microorganisms, including sulfate reducing bacteria and those responsible for degrading TCE. The studies have also revealed that a genetically modified metal tolerant TCE degrader (Burkholderia cepacia $\mathrm{PR}_{301}$ ) demonstrates greater resistance to $\mathrm{N}$ at $\mathrm{pH} 5$ rather than $\mathrm{pH} 6$ or 7. It has also been demonstrated that phosphate in the form of hydroxyl apatite can mitigate Ni toxicity.

- Studies using earthworms as bioreceptors demonstrate significant $\mathrm{U}$ and $\mathrm{Ni}$ accumulation upon exposure to Steed Pond and Tim's Branch sediments and bioaccumulation was related to chemical speciation rather than total concentration. The results also identify an artifact for $\mathrm{U}$ accumulation in the EPA earthworm exposure protocol when applied to naturally acidic riparian zone soils found on the SRS.

- Studies have demonstrated the importance of hydroxy interlayered vermiculites, the last remaining relics of weathered micaceous minerals in SRS soils, at controlling Cs sorption dynamics.

- Unsaturated column experiments using the Unsaturated Flow Apparatus (UFA), a novel centrifuge-based instrument, and a more common vacuum-based technique have addressed the apparent changes in contaminant partitioning and transport in variably saturated media. Both the physical dispersion and contaminant partitioning to the solid phases apparently increase with decreasing water content.

- Isotope ratio mass spectrometry (C- and N-stable isotopes) was used to determine the trophic pathways of contaminant uptake and the co-association of contaminants (e.g., Se and $\mathrm{Hg}$ ) in biological tissues of 
invertebrate and vertebrate species on the SRS and elsewhere.

- Existing information on the distribution of metals (e.g., $\mathrm{As}, \mathrm{Cd}, \mathrm{Cr}, \mathrm{Fe}, \mathrm{Al}, \mathrm{Hg}, \mathrm{Pb}$, and $\mathrm{Zn}$ ) in surface soils of the SRS was collected and incorporated in a GIS coverage that was used to predict the metal concentration of soils at various scales across the SRS. The coverage provides a geospatial representation of potential source terms that can be used to study contaminant uptake and transfer in natural and impacted ecosystems on the SRS. 


\section{Ecological Stewardship}

Most (90\%) of the Savannah River Site (SRS) is not industrialized. These lands nevertheless are susceptible to various ecological risks. For example, management practices such as timber harvest, maintenance of power line rights-of-way, management of wildlife populations, or placement and operation of new facilities create potential risk because they can reduce biological or landscape diversity, increase unwanted organisms, or threaten rare or desirable taxa. Moreover, management practices may affect movement of various contaminants into or from these lands. Management of the SRS requires data-intensive research and monitoring that provides meaningful land stewardship recommendations to minimize ecological risk and promote ecosystem health. This program includes research relevant to ecological land management, ecosystem structure and function, and stewardship and provides advice to the U.S. Department of Energy (DOE) on management of the SRS using concepts such as ecological integrity and risk assessment. The focus is to examine effects of land use patterns on abiotic and biotic resources in watersheds; on the communities, populations, and individuals within them (with an emphasis on rare species and those with localized distribution); and on restoration of degraded and contaminated systems.

Ecological Stewardship research program studies will:

$\square$ Assess the current status of impacted, degraded, and less altered ecological systems;

Conduct research on various organisms as bioindicators and biodetectors of environmental contamination;

Examine biodiversity patterns of organisms in protected and disturbed sites;

口 Conduct research to restore damaged systems;

口 Conduct research relevant to site remediation, such as phytoremediation of contaminated wetlands and forest management to reduce movement of contaminants within watersheds; and

Develop recommendations for ecologically sound management of SRSland.

The Ecological Stewardship Program will interface with SRS management professionals to:

$\square$ Participate in decision-making activities and issue-related task groups;

ㅁ Develop a system to better inform SRSmanagers about ecological issues and our knowledge base;

口 Increase transfer of ecosystem management technologies to SRS, other DOE facilities, and other land management agencies; and

口 Interface with SRS groups and professionals from other DOE sites to develop workshops that explore and establish new approaches to land use and ecological risk assessment. 
Impact of SRS Clean-Up on the Biological and Functional Diversity of Aquatic Bacteria

Principal Investigator: J Vaun McArthur

Bacteria are involved in all ecosystem level processes including nutrient cycling and organic matter decomposition. Furthermore, microbial processes are the primary mechanisms used for in situ remediation of contaminated sites. It is not clear what the chronic effect of contamination is on bacterial populations and/or functional diversity. These studies seek to detail the effects of various contaminants on the biological and functional diversity of bacteria in surface waters on the SRS. In particular we are investigating the effect of inorganic mercury on the distribution of antibiotic resistance among stream bacteria. We have begun a collaborative study with colleagues at the Medical College of Georgia. Results of these studies provide information on the ability of natural populations to respond to contaminants and the length of time required for recovery of biological and functional diversity following cleanup.

- Developed primers to amplify $\operatorname{Tn} 21, \mathrm{Tn} 5$, and integron 2 transposable elements known to carry both antibiotic resistance genes and metal tolerance genes.

- Screened over 800 fish collected from Four Mile and Meyers Branch Creeks and screened all fish for Aeromonas hydrophila and all bacteria for antibiotic resistance.

- Determined the minimum inhibitory concentration of metals against several bacterial taxa.

- Submitted a proposal to $\mathrm{NH}$ to fund this research.

- Interviewed candidate postdoctoral associates to work on this project.

\section{Land Management in SRS Watersheds}

Principal Investigators: Beverly S. Collins, J Vaun McArthur, Christopher S. Romanek, and Rebecca R. Sharitz

This program investigates land management effects on dynamics of SRSecosystems and the plant species they harbor in upland forests and along upland to floodplain gradients within watersheds. Land management practices, including thinning and prescribed burns for forest management, impact SRS ecosystems and shape biodiversity. At the landscape level, land management practices can affect flow of energy and materials, including contaminants, among ecosystems. For example, forest managementactivities, such as prescribed burns, can affect nitrogen cycling and movement from uplands to floodplains within a watershed. The form and amount of soil nitrogen can influence diversity and plant species composition within the watershed, and may affect mobility of other elements, including ${ }^{137} \mathrm{Cs}$ in floodplain sediments.

This research is being conducted in collaboration with the U.S. Forest Service-Savannah River (USFS-SR) to investigate aspects of forest management on key ecosystems within watersheds. It incorporates two sets of sites with specific management histories and goals.

Land management effects on small mammals, seed predation and vegetation, and nitrogen dynamics are being compared among ten upland pine and pine-hardwood forests that differ in forest management history. A specific objective of this research is to determine if forest management to enhance Red-cockaded Woodpecker (RCW) habitat influences small mammal populations, potential forest regeneration and biodiversity, and nitrogen transformations. In each site, canopy and ground layer vegetation were surveyed in 2001. Small mammal populations are being estimated. Litter and seed collection traps were arrayed in summer 2001. Acorn removal by small mammals was observed over winter 2001, and oak seedling recruitment is being monitored. Nitrogen transformations, including litter decomposition and mineralization, will be determined by field assays.

Forest management effects on vegetation and soil nutrient dynamics are being investigated in two watersheds. Sets of lysimeters were installed in disturbed and undisturbed plots along slopes from managed pine uplands to bottomland hardwood forest at the Meyers Branch Set-Aside and Tim's Branch. The lysimeters are sampled through the growing season, before and after forest management treatments to provide information on quantities and forms of nitrogen that are being moved down slope in surface and shallow groundwater flows. Vegetation surveys are being conducted in each site to determine forest management effects on vegetation composition. These procedures are investigating land management effects on biodiversity within the two watershed regions, including the extent to which management practices are not sustainable. 
- Vegetation surveys reveal frequently-burned RCW sites have the most grass cover, xeric sandhills sites have the most shrub cover, long-unburned sites have the most reindeer moss cover, and relatively unmanaged Meyers Branch Set-Aside slopes have a mix of forb, vine, and sapling cover.

- The relatively unmanaged Meyers Branch sites have the largest numbers of small mammals, with approximately 5 per hectare; the highestrate of acorn removal ( $98 \%)$; and greatest litterfall.

- RCW sites have intermediate rates of acorn removal (67\%), lowest litterfall, and are the only sites with significant red oak seedling mortality.

- $\mathrm{NO}_{3}-\mathrm{N}$ and root simulator probe (PRS) uptake of $\mathrm{N}$ increased from upland pine forest downslope to deciduous bottomland at Meyers Branch. PRS uptake was greater in thinned than undisturbed forests at Tims Branch.

\section{Recovery of Endangered Plants}

\section{Principal Investigator: Beverly S. Collins}

This project provides information to enhance recovery of plant species of special concern on the SRS. The most important species is the smooth purple coneflower, Echinacea laevigata, which occurs in three populations on the SRS. The first two populations, Burma Road and Road B-9, have been monitored since 1988 and 1996, respectively. The third population, Tennessee Road, was located in June 1999 in Forest Compartment 85; monitoring began during summer, 2000. Echinacea is federally endangered, and is listed as a sensitive species by the U.S. Forest Service. Echinacea populations on the SRS have been exposed both to threats, including power line maintenance activities and accidental herbicide application, and to management practices that may improve the populations, including forest thinning and burning. The federally endangered designation requires DOE to avoid actions with deleterious impacts to the plants.

Although this research is focused primarily on smooth purple coneflower, it will include other plant species of concern. One of these, Trillium maculatum, occurs on slopes along Lower Three Runs Creek. This population, the only one known on the SRS, was discovered in 1999.
This research program combines demographic analyses with experimental manipulations to investigate maintenance and recovery of threatened plant species. It continues demographic monitoring of the three SRS populations of smooth purple coneflower. In addition, it investigates basic biology of the coneflower and the species' response to management practices. Demography of the Trillium population is being monitored by censusing plant size and reproductive state each year. This project contributes to DOE's obligations under the Endangered Species Act. It collaborates with and complements U.S. Forest ServiceSavannah River (USFS-SR) programs for rare and endangered species.

- The Burma Road coneflower population fluctuates, but is declining over time. From 1997 through 2001, there were 137, 156, 130, 95, and 90 plants, with an average 2.2 stems per plant in 2001.

- The Road B-9 coneflower population fluctuates. The number of stems declined from 1,929 in 1999; to 1,698 in 2000, which was a drought year; and 1534 in 2001, which was also a drought year. There were 418 plants in 2001, with an average 3.7 stems per plant.

- The Tennessee Road coneflower population had 204 plants and 517 stems, for an average 2.5 stems per plant in 2000. This population declined to 182 plants and 443 stems, for an average 2.4 stems per plant in 2001.

- The proportions of flowering stems in the three coneflower populations were $24 \%$ in the Tennessee Road population, 19\% in the Burma Road population, and $27 \%$ in the most open, Road B-9 population.

- The Trillium maculatum population in a sample transect increased from 50 plants in spring 2001 to 1,786 plants in 2002 . The structure of a sample population was $7.2 \%$ new germinants, $7.1 \%$ single-leaf juveniles, $66 \%$ three-leaf juveniles, and 20\% flowering plants.

\section{Wetland Restoration and Ecosystem Sustainability}

Principal Investigators: Rebecca R. Sharitz, Beverly S. Collins, and Barbara E. Taylor

The U.S. Department of Energy (DOE) is committed to restoring disturbed wetlands to mitigate wetland losses and to demonstrate good land management practices. The 
Savannah River Site (SRS) has approximately 300 isolated depression wetlands (Carolina bays), many of which were drained by previous landowners or have been disturbed by SRS land management activities so that they no longer function as wetlands. This multidisciplinary research program seeks to determine the most cost-effective and successful methods for restoring hydrologically altered Carolina bays to sustainable wetland ecosystems for mitigation banking purposes. Specific objectives are: (1) to evaluate bay restoration treatments that represent realistic land management options for the SRS; (2) to determine if bays under restoration are moving toward abiotic and biotic endpoints as determined from reference bays; and (3) to assess functional differences among land management alternatives and develop predictions of how these alternatives may provide suitable habitatfor key plantand animal species.

Researchers from SREL and the USDA Forest Service, along with collaborators from Clemson University and the University of South Carolina atAiken, are conducting a multidisciplinary study of management practices that may lead to cost-effective Carolina bay wetland restoration. Twenty drained bays were selected for study; of these, 16 are being restored using techniques suggested from a pilot study and 4 are controls. Additional functional bay wetlands serve as reference sites.

The prescription for restoration included closing the drainage ditches, removal of woody vegetation, and planting appropriate species to establish two wetland community types: 1) open wetland meadow of grasses and herbs, and 2) forested wetland savanna. In addition, because of debate about the impacts of buffer-zone management on wetland properties and wildlife usage, two alternative strategies for managing the wetland margins are being tested. One strategy is to maintain the margins as unburned, closed-canopymixed pine-hardwood forests, and the other is to manage them as open-canopy pine woodlands that are periodically burned. SREL studies have focused on the vegetation and wetland invertebrate communities.

Pre-restoration characterization of the hydrology, soils, and biota of the bays was completed in 2000. The bays were mapped, and the potential mitigation credits for the DOE-SR Wetland Mitigation Bank were determined. The seed bank in the soil was sampled to predict natural establishment of wetland vegetation in the interiors of the restoration bays; these data are being analyzed. Research that examined seed bank and vegetation patterns within and among six functioning, herbaceous Carolina bays has shown thatyearly patterns of hydrology influence plant species composition and recruitment from the seed bank. Bays, and areas within bays, that experience fluctuating water levels within a season tend to recruit from the seed bank, are rich in plant species, and lack discrete vegetation zones.

Aquatic invertebrates were studied extensively prior to restoration. Both macro- and micro-invertebrates were characterized in three years of bimonthly sampling. Experimental studies were conducted to determine which species persist in resting stages during the dry season and which recolonize when the wetlands are inundated. Hydroperiods in most of the pre-restoration ponds were short ( standing water present for $20-30 \%$ of the year). These ponds had fewer species of invertebrates, for example, typically 10-20 species of microcrustaceans, compared to ponds with long hydroperiods, which supported 30-50 species. Lengthening the hydroperiod generally increases species richness, although a few taxa with resting eggs specialized to withstand extended desiccation, such as clam shrimp Lynceus gracilicornis and the large red calanoid copepod Aglaodiaptomus stagnalis, may appear less frequently or become locally extinct. Comparison with a benchmark data set for 88 ponds on the SRS resulted in predictions that herbaceous wetlands will gain more species than the forested wetlands.

Restoration activities began in the winter of 2000/2001. Trees were harvested and removed from the bay interiors by the Forest Service, and margin treatments were established. Seedlings of two wetland tree species, bald cypress (Taxodium distichum) and swamp tupelo (Nyssa biflora), were planted throughout the forested savanna bays in the winter/spring of 2001. Two species of wetland grass, maidencane (Panicum hemitomun) and leersia (Leersia hexandra), were planted in experimental blocks in the herbaceous meadow bays. Monitoring of vegetation development in planted and unplanted areas of the restoration bays began in the summer of 2001. Major accomplishments include:

- Pre-restoration characterization of the physical conditions ( size, depth, hydrology, soils) and biota ( plant and invertebrate communities) of the restoration bays has been completed. 
- Restoration treatments have been installed, including clearcutting and removal of woody vegetation, thinning of pine woodland margins, planting of wetland tree seedlings and planting of wetland grasses. Ditches were closed in the winter of 2001/2002. Dry conditions have precluded burning of the pine woodland margins.

- Post-restoration monitoring of plant community development was initiated in the summer of 2001. Initial survival of planted wetland tree seedlings was determined in fall 2001 and spring 2002.

- Potential mitigation credits were determined and proposed to DOE-SR.

\section{Research on the Spatial Distributions of Biotic and Abiotic Features of Savannah River Site Reservoirs}

\section{Principal Investigator: Steven J. Harper}

Scientists have historically sampled the physical and biotic components of a lake at a few locations, or even a single site, and have assumed that these limited samples are representative of the entire lake. For well-mixed homogeneous systems such as some natural lakes, this may be reasonable. However for heterogeneous systems, such as man-made reservoirs, this approach ignores inherent spatial structure. Thus, while vertical distributions of certain features (e.g., clines in temperature, dissolved oxygen, and light) have been well studied by aquatic ecologists and limnologists, the spatial distributions of these same features in the horizontal dimension have been largely ignored. Greater understanding of the spatial context of processes operating within a system allows for increased knowledge about the system as a whole, and also provides support for sound and defensible management decisions. For example, the utilization of specific habitats or locations by target species is an important component of impact assessment, so greater understanding of the spatial distributions of organisms within local reservoirs would directly benefit ecological risk assessment efforts.

Research is being initiated that will describe the spatial structure of important biotic and abiotic features of several Savannah River Site reservoirs through the use of technologically advanced sampling gear. Objectives are to: (1) document spatial patterns of biotic (fish biomass, phytoplankton biomass, and submerged aquatic vegetation) and abiotic features (bathymetry, sediment class type, temperature, dissolved oxygen, $\mathrm{pH}$, and turbidity), (2) determine how spatial patterns differ among reservoirs and change over time within a reservoir, and (3) quantify the extent to which biotic and abiotic features are interrelated. Extensive surveys will be conducted on the larger Savannah River Site reservoirs throughout the year using technologically advanced sampling gear. Hydroacoustic sampling equipment will allow the fish community to be sampled efficiently within limnetic regions of reservoirs. One fish species that will receive special consideration is the sediment-feeding gizzard shad (Dorosoma cepedianum), a common species that represents the largestpercentage of total fish biomass in many southeastern reservoirs. Because gizzard shad directly consume sediments and are prey to numerous terrestrial and aquatic predators, improved understanding of this species could benefit management objectives specific to the Savannah River Site. Their extremely patchy distribution ( due to schooling behavior and shifts in the use of inshore and offshore habitats) makes itimperative to incorporate a spatial component in studies of gizzard shad. Little is currently known abouthow biotic and abiotic factors interact to affect the abundance, size-class structure, and habitat use of this species.

- A combination of side-looking and down-looking hydroacoustic surveys will be used to determine the locations, abundances, and size-class distributions of gizzard shad and other fish species. Surveys will be conducted using a BioSonics digital hydroacoustic system with circular 75- and 200-kHz split-beam, 6degree cone angle transducers. This approach is expected to result in increased precision with reduced labor compared to traditional fish sampling techniques such as cove rotenoning, seining, or electrofishing.

- Echo-integration algorithms, fish identification methods, and condition factor estimates will be developed in support of hydroacoustic samples using supplemental electrofishing and trawling surveys.

- Multiple transducer frequencies will be used during hydroacoustic surveys to provide spatial information about bathymetric topology ( e.g., depth, distance from bank, and slope), lake-bottom sedimentclass types, and abundance of submerged aquatic vegetation ( SAV).

- Spatial distributions of additional abiotic and biotic parameters will be determined using equipment that provides rapid in-situ measurements of temperature, 
dissolved oxygen, pH, turbidity, and chlorophyll-a (an index of phytoplankton biomass). Surveys will be conducted using a YSI 6600 multiparameter sonde and datalogger. Sensors will be calibrated routinely in the laboratory and field to prevent dritt, and independent measurements will be taken to validate turbidity and chlorophyll-a estimates.

- Transect surveys will be conducted in the limnetic zone of each reservoir during multiple times of day and regularly throughout the year. This will allow not only the spatial structure of each reservoir to be determined and compared with other reservoirs, but also the diel and seasonal changes in spatial patterns to be quantified. Statistical relationships among measured variables will be determined using classical and more advanced parametric and nonparametric analyses.

\section{Data Analysis in Ecology and Environmental Monitoring}

Principal Investigator: Machelle Wilson

As a new faculty member, just beginning my research program in the Fall of 2001, I hope to focus on developing novel approaches to problems in data analysis in ecology and environmental monitoring. Myresearch interests include statistical methods in ecology, environmental monitoring, and analytical chemistry. My current research includes:

- Developing and testing a new statistic for estimating the maximal exposure in a population of animals using Monte Carlo simulation and bootstrap;

- Fitting growth curves to assess determinate or indeterminate growth in turtles at the SRS;

- Multivariate analysis of different treatments for immobilization of heavy metals in contaminated soils;

- Comparing the effectiveness of support vector machine classification to partial least squares/logistic discrimination in the classification of plants exposed to heavy metals or petroleum using high dimensional remotely sensed reflectance ( hyper-spectral) data;

- Comparing step-wise multiple regression to partial least squares regression of hyper-spectral data;

- Extending the application of a two-component model for chemical analytical error to problems in environmental monitoring;
- Using time series analysis to model periodicity in chemical content of whale baleen caused by yearly migration patterns; and

- Constructing regression models to predict soil dispersability using several soil variables.

\section{Research on SRS Herpetofauna for Application to Monitored Natural Attenuation Studies, Assessing the Distribution of Sensitive Species, and Examining Biodiversity Patterns on a Protected Site}

Principal Investigator: J. Whitfield Gibbons

The southeastern United States has the highest biodiversity and abundance of reptile and amphibian species in North America. The U.S. Department of Energy's (DOE) Savannah River Site ( SRS) is noted for a particularly rich herpetofaunal biodiversity and has been the focus of extensive inventory and research since 1951. The SRS is the largest tract of land in North America for which herpetofaunal species abundance, distribution, and diversity have been measured on a long-term basis (more than 50 years). Since the first surveys and other studies were initiated, more species of herpetofauna have been documented than have been reported from any other public land area in the United States.

The goal of current studies is to capitalize on this enormous database and herpetological experience by supplementing previously collected information with studies designed to enhance DOE's environmental commitment, involving issues as diverse as documenting potential responses (e.g., mutations) of organisms to local contamination, determining distribution and abundance of sensitive species that have potential for regulations that could restrict site activities, contributing to monitored natural attenuation programs, and establishing the extent of dispersal of organisms from radioactively or chemically contaminated sites. All of these projects have been natural extensions of an original goal of documenting species status and trends on the SRS. One conclusion has been that the SRS is one of the most highly biologically diverse tracts of land in the Upper Coastal Plain as a consequence of long-term environmental protection of native habitats. These studies serve to confirm the assumption that environmental health of the SRS is high in comparison to surrounding regions as well as having direct applicability to the Endangered Species Act, the site initiative of 
environmental cleanup, and to DOE- Land Use and Facilities Management policies and environmental stewardship. We recommend, based on a long-standing program of ecological research on the SRS and familiarity with environmental concerns at the national level, that all activities on the SRS, especially facility development and forestry activities, be carefully assessed in terms of both short- and long-term environmental impact. A thorough environmental research program that is in concert with the environmental alterations necessary on the SRSwill resultin responsible environmental management, both actual and perceived. These studies focus on herpetofauna, which include two major vertebrate groups, the amphibians and reptiles, found on the SRS.

- SREL continues to be recognized nationwide as a major site for herpetological research and education.

- SREL continues to operate the Partners in Amphibian and Reptile Conservation (PARC) national website (www.parcplace.org), to serve as the nexus for herpetofaunal databases throughout the country. Two databases, Research pertaining to the management of herpetofauna and Herpetofaunal studies on federal lands, are almost completed and will be offered on the PARC website in the coming months. More than 44,000 copies of the book Snakes of Georgia and South Carolina have been distributed, and most have been paid for by outside sponsors in the private sector as well as state and federal agencies.

- The herpetology website (www.uga.edu/srelherp/) continues to be developed and refined. This site has been visited by more than 73,000 viewers and has generated numerous queries from interested individuals.

- The monitoring of Rainbow Bay reptiles and amphibians continued for its 24 th year, as recommended by the SRS Citizens Advisory Board.

\section{Restoration Ecology of Highly Impacted Forested Floodplain Ecosystems}

Principal Investigators: J Vaun McArthur, Kenneth W. McLeod, and Rebecca R. Sharitz

Thermal effluents from reactor operations ceased almost a decade ago and while natural succession of the streams and flood plains is occurring, these ecosystems remain different from unimpacted reference systems. By contrasting the impacted and unimpacted systems, this research investigates the trajectory and rate of natural recovery and the similarity of the disturbed systems with natural systems, and contrasts that with areas in which restoration has been attempted. Emphases have been placed on recovery of wetland woody vegetation and establishment of macroinvertebrate communities. Our research has the following specific objectives: (1) determine whether these ecosystems have a balanced indigenous community; (2) determine the effect of various large-scale restoration practices on the recovery trajectories of these ecosystems; and (3) experimentally determine "best" restoration strategies for specific biotic components of the system.

- Natural re-vegetation of woody species from 1985 to the present has been dominated by wind-dispersed species, such as black willow (Salix nigra), loblolly pine (Pinus taeda), and ironwood (Carpinus caroliniana), but in the interior of the delta additional species are now becoming established. For example, even as late as 1989 , only one species occurred in the interior plots, but now five or six species are found.

- Basal area and density of the trees has also increased tremendously. In 1987, basal area was $<1.0 \mathrm{~m}^{2} /$ ha, but now ranges between $4-17 \mathrm{~m}^{2} /$ ha in the delta interior, while density has increased from 40 to 400 trees/ha over the same time period.

- A resurvey of the natural recovery plots is currently in progress.

- A research shift from studying structure to function of the forest is being examined in a current mesocosm experiment that examines the role of early and late successional tree species in controlling nitrogen dynamics.

\section{Restoration of Longleaf Pine/Sandhills Communities}

Principal Investigators: Kenneth W. McLeod and Beverly S. Collins

In the southeastern United States, vast areas were once covered by longleaf pine-dominated communities. Most of the original acreage of these fire-maintained communities has been urbanized or converted to agriculture or forestry. Along the fall line sandhills that remain, fire suppression 
has allowed less fire-tolerant oak species [ turkey oak (Quercus laevis), scrubby post oak (Q. margaretta), bluejack oak (Q. incana)] to increase in importance while longleaf pine ( Pinus palustris) has declined. Natural stands of the various longleaf pine community types are uncommon. Reductions in the extent of these communities have limited several plant and animal species such that they currently require federal protection. This program conducts research to guide land managers in management and restoration of the under-represented longleaf pine/sandhills communities.

This program is currently being leveraged by a several grants from Strategic Environmental Research and Development Program ( SERDP) Ecosystem Management Program ( SEMP) to Beverly Collins, Tom Hinton, J Vaun McArthur, Chris Romanek, John Seaman, Rebecca Shariz, and two other nonSREL principal investigators. These grants support research in other sandhills sites at Ft. Benning near Columbus, GA and Ft. Gordon near Augusta, GA. Much of the overall research results are being reported in the annual report for each of those grants.

- Two sandhills sites were included in a study of seed predation by small mammals in habitats ranging from slope deciduous forest to upland pine forests. Among these habitats, sandhills sites had the greatest shrub cover and the least removal of southern red oak (Quercus falcata) acorns by small mammals, primarily cotton mice (Peromyscus gossypinus). Southern red oak seedlings planted in April continue to do well, giving some evidence that species establishment by seeding or planting seedlings might be successful. There was also considerable soil moisture variation related to seasonal activity of the vegetation.

\section{Phytoremediation of Contaminants in Constructed and Natural Wetlands}

Principal Investigators: J Vaun McArthur, Kenneth W. McLeod, and Beverly S. Collins

Wetlands on the SRSand at other DOE sites contain mixtures of chemical pollutants, including volatile organic compounds, metals, and radionuclides. Current cleanup technologies are expensive. Technologies that are less invasive and expensive, but still stabilize and contain contaminants in situ, would be highly desirable. Various plant species have been shown to stabilize, filter and/or extract excess nutrients, organic solvents, metals, and radionuclides. Thus, plants can playa major role in stabilizing and remediating wetlands.

In addition to the stabilization and extraction functions of plants, their use of water will reduce migration of contaminated groundwater by reducing the amount of downward water movement. Further, the structure and chemical environment of plant roots provides favorable conditions for fungi and microorganisms that can degrade contaminant compounds. Plant-based remediation could be used in situations where contamination level is low, risk to the public is low, and where slower, low-cost cleanup can be substituted for an immediate and high-cost cleanup.

Our objectives are to: (1) investigate the tolerance and uptake rates of contaminants by various native wetland species, (2) characterize the microbial assemblages associated with each native plant species, and (3) determine what combinations of plants/microbial assemblages best degrade contaminants.

In 1997, water tupelo (Nyssa aquatica) and bald cypress (Taxodium distichum) seedlings were planted in the FArea seepline. Through the summer of 2000, 20\% of the water tupelo had died, but none of the bald cypress. Leaf samples taken each year indicate the manganese and cobalt concentrations continue to rise by about $10 \%$ per year. Presently, water tupelo leaf $\mathrm{Mn}$ and $\mathrm{Co}$ concentrations are 5260 and 389 ppm, respectively. These concentrations are 20 and 200 times higher in water tupelo than in bald cypress. These differences between species and elements are consistent with uptake experiments conducted in the greenhouse under more controlled environmental conditions with $\mathrm{Mn}$ - and Co-amended soils.

- We continue to follow the fate of water tupelo (Nyssa aquatica) and bald cypress (Taxodium distichum) seedlings planted in the F-Area seepline. Through the summer of $2001,40 \%$ of the water tupelo had died, but only $10 \%$ of the bald cypress. Leaf samples show that the manganese, cobalt, and aluminum concentrations are 24,192, and 11 times higher in water tupelo than in bald cypress, respectively. Water tupelo leaf $\mathrm{Mn}, \mathrm{Co}$, and Al concentrations slowly rose over the years but have stabilized at approximately 5200, 385, and 420 
ppm, respectively. These differences between species and elements are consistent with uptake experiments previously conducted in the greenhouse with $\mathrm{Mn}$ - and Co-amended soils.

- Bald cypress continues to show a greater overall ability to tolerate fly ash associated stresses. Since outplanted into the D-Area ash basin in February, bald cypress seedlings have a $88 \%$ survival rate, compared to $29 \%$ for water tupelo. While the seedlings have survived, growth is minimal.

- Water quality was not significantly different between mesocosms with plastic plants and those without plants. However, both of these treatments differed from tanks with real plants in them.

- Bacterial assemblages associated with real and plastic plants differed both among treatments and seasonally.

\section{History of Environmental Change on the Savannah River Site}

Principal Investigators: Barbara E. Taylor and Mark J. Brooks ( Savannah River Archaeological Research Program)

We are using palaeoenvironmental records to clarify regional and local responses of climate and landscape to change in global climate during the Pleistocene and Holocene. Organic carbon, pollen, and siliceous microfossils provide records from the basins of Carolina bays and other isolated wetlands; sediment stratigraphy and archaeological sites provide records from adjacentridges and dunes. Our current studies focus on three times of change: (1) episodes of warmer and moister climate resulting in development of Carolina bays during the mid- to late Pleistocene; (2) a hydrologic threshold during the mid-Holocene; and (3) a possible moister episode beginning in late prehistoric times. This research contributes to our understanding of the history of climate and the responses of southeastern ecosystems. Because the region has been well populated with humans since atleast $13,000 \mathrm{yr}$ B.P., these changes are important to human history, as well as to ecological history.

This research continues to be a cross-disciplinary effort. Current collaborators include: Dr. Chris Clement, South Carolina Institute of Archaeology and Anthropology; Dr. Evelyn Gaiser, Florida International University; Dr. Robert Gardner, University of South Carolina; Dr. Andrew Ivester,
West Georgia State University; Peter Stone, South Carolina Department of Health and Environmental Control; and Dr. Eric Wright, Coastal Carolina University.

Sand dominates the sediments of the Coastal Plain in South Carolina. Some climatic regimes have resulted in wind-driven formation of localized dune fields, ridges, and other features, including Carolina bays. Big Bay, a large ( 3 x $5 \mathrm{~km}$ ), oval Carolina bay on the PoinsettElectronic Combat Range of the U.S. Air Force in Sumter County, SC, contains a series of wellseparated concentric beach ridges. We hypothesize that these ridges represent the positions of the active bay margin during successive periods of dry climate associated with glacial advances of the Wisconsinan period of the late Pleistocene. Most of the interior of the bay burned in spring of 2001, permitting access to the innermost of these ridges. In July 2001, we recovered three continuous cores of 3 to $4 \mathrm{~m}$ length from the ridge and adjacent swale using a vibracore. We also collected samples from several ridges for dating by optically stimulated luminescence (OSL), a technique that dates time since last exposure to sunlight. This technique is a valuable complement to radiocarbon dating, which cannot provide reliable ages for materials older than 30,000-50,000 yr B.P. OSL extends this limit by about 100,000 yr. Further, datable material can be obtained from features of the uplands where old organic carbon is seldom preserved. Research at Big Bay has been facilitated by the natural and cultural resource management programs of the U.S. Air Force.

At least some of the episodes of increased sediment mobility at Big Bay were probably regional in scale. At Flamingo Bay on the SRS, OSL dates from the base of the sand rim indicate that the overlying sand was deposited around $110,000 \mathrm{yr}$ B.P. Our previous studies established that the sediments on the rim were wind-deposited, presumably during formation and development of the basin. Dates of 40,000 yr B.P. (OSL) and 9000 yr B.P. and later (chronologically diagnostic archaeological artifacts) from overlying strata show that deposition continued over a very long time.

Organic sediments within Carolina bays typically yield basal dates much younger than the known ages of the bays. Most of them probably reflect transitions to moister climate, resulting in episodes of paludification (i.e. becoming marshy) that permitted organic materials to accumulate in the basins. Accumulated organic material would oxidize during periods of prolonged desiccation under drier 
climates, so that only material from the most recent moist episodes is preserved. Evidence from two basins on the SRS suggests transitions to moister conditions during the midHolocene and, unexpectedly, during late prehistoric times. At Flamingo Bay on the SRS, the oldest basal organic date from the central portion of the basin is $4500 \mathrm{yr}$ B.P., and basal organic material from shallower portions of the basin is substantially younger. On a ridge ( surfaces $80-90 \mathrm{~cm}$ above the deepest part) in the interior of the basin, basal dates were $\sim 300$ yr B.P. A 5000-yr record of fossil diatom assemblages from Peat Bay, another wetland on the SRS, corroborates the inferences of moister conditions during these periods.

We are now using modern records to quantify changes in precipitation required to produce the responses recorded in the sediments. Extensive modern records from several Carolina bays indicate that inundation $>50 \%$ of the year is required for preservation of charcoal and similar organic materials. Water level at Flamingo Bay can be accurately modeled as a function of cumulative precipitation for the year. (The model was constructed using 14 years of monthly water level data and the corresponding weather records from Blackville, SC). We can use these relations to estimate precipitation thresholds required for the accumulation and preservation of organic materials at different elevations within the basin.

Modern precipitation averages $120 \mathrm{~cm}$ annually. Our analyses suggests that a prolonged episode of $\sim 100 \mathrm{~cm}$ annual precipitation occurred prior to 300 yr B.P., when organic sediments began to accumulate at elevations of $80-90 \mathrm{~cm}$ in the basin atFlamingo Bay. The diatom record from Peat Bay suggests that this threshold was reached by progressive, rather than abrupt, increases in precipitation beginning about 1600 yr B.P. Conditions preceding the mid-Holocene were likely more arid (perhaps $<80 \mathrm{~cm}$ annual precipitation), but we do not yet have preponderance of evidence for either progressive or abrupt shifts. A goal of our ongoing research is to improve the models, refine these inferences, and identify sites where additional data to test the hypothesized changes may be obtained. 


\section{Ecotoxicology, Remediation, AND} RISK Assessment (ETRRA)

TheU.S. Department of Energy (DOE) has responsibility for a number of contaminated sites resulting from more than 40 years of operations. There is a clear need for information about the fate and effects of these contaminants and effective strategies for site remediation or cleanup. To address these needs, the ETRRAGroup conducts research on ecotoxicology and remediation, provides data and information for use in risk assessment, and interfaces with Savannah River Site (SRS) environmental management and risk assessment professionals.

ETRRA's research activities include:

$\square$ Studies of the fate and effects of contaminants at all levels of ecological organization;

Evaluation of the effectiveness of remediation activities;

- S Studies relevant to SRS environmental professionals, including risk assessors;

- Generation of ecological and ecotoxicological baseline data; and

口 Development and application of new methods for assessing impact, risk, and recovery.

ETRRAinterfaces with SRS management and remediation professionals by:

- S Supporting environmental management and risk assessment activities;

口 Integrating and synthesizing Savannah River Ecology Laboratory information applicable to SRS environmental management and risk assessment; and

口 Providingscientific and technical expertise in ecological and toxicological fields.

ETRRA communicates with SRSand other environmental professionals by:

$\checkmark$ Promoting interactions between SRS professionals and outside experts;

ㅁ Writing and editing books and documents on ecotoxicology, remediation, and risk assessment, which contribute knowledge relevant to SRSand other DOE site activities;

口 Publishing high-quality research relevant to SRSgoals in peer-reviewed journals; and

․ Presenting research findings at local, national, and international forums. 
Cycling of Mercury in SRS Waters and Accumulation by Fish and Wildlife; Effects of Heavy Metals on Biota

Principal Investigators: Charles H. Jagoe and I. Lehr Brisbin,

This program provides continuing support of regulatory compliance and ecological risk assessment needs at the SRS by producing information on the cycling, uptake, and effects of mercury and other trace metals in SRSterrestrial habitats, reservoirs, waters, and wetlands. By documenting mercury and selected trace metals in fish and other biota over time, and identifying the key watershed processes that control accumulation of metals in biota, land management impacts can be minimized. Field and laboratory studies within this program also explore potential negative effects of ongoing metal exposure on SRS fish and wildlife. This program provides data to support compliance with state and federal regulations concerning allowable mercury burdens in fish and wildlife. Site activities involving the future of L-Lake or other reservoirs, or Carolina bay restoration, may also alter mercury bioavailability, raising regulatory and risk assessmentissues involving the U.S. Environmental Protection Agency, U.S. Fish and Wildlife Service, and South Carolina Department of Natural Resources. This program closely integrates with the Compliance-Associated Monitoring and Risk Assessment for the Endangered Wood Stork program and the Studies of the Fate and Effects of Nuclear Industrial Contaminants in Wildlife of the Savannah River Site program, byproviding data relevant to considerations of dietary intakes byfish, wildlife, and human consumers. This program differs from the others by focusing on the basic mechanisms by which mercury enters and accumulates through food webs, and the potential effects of mercury and other metals on exposed organisms. Mechanisms of accumulation are dependant on transformation processes (methylation and demethylation) that occur in soils and waters and control the concentration and availability of methylmercury, the major form that accumulates in biota. This program has documented mercury concentrations in SRS reservoirs, and the effects of various management activities on contaminant concentrations. Ithas also provided information on mercury in organisms living in Carolina bays, and has shown that differences in mercury concentrations in biota over spatial and temporal scales are influenced by water chemistry, changes in water level, flooding and drying of soils, and other factors. This program has also contributed to the evaluation of potential risks of dietary mercury exposure to wildlife, including threatened and endangered species such as the Bald Eagle and Wood Stork.

- A final report on potential risks of mercury and other contaminants to Bald Eagles foraging in SRS reservoirs was published. This report also included development of a novel statistical method for assessing the probability of contaminant concentrations in the diet of an eagle (or other wildlife) exceeding regulatory limits. The diet of eagles foraging on SRS reservoirs is likely to exceed current U.S. Fish and Wildlife Service guidelines for mercury for sensitive avian species. Concentrations of other heavy metals ( $\mathrm{Cd}, \mathrm{Co}, \mathrm{Cu}, \mathrm{Mn}, \mathrm{Ni}, \mathrm{Pb}$, and $\mathrm{Zn}$ ) in fish from SRS reservoirs do not appear high enough to cause concern.

- A paper was published showing potential risks of mercury exposure to wading birds such as Wood Storks that might forage in Carolina bays on the SRS. Nestlings were at higher risk than adults, and hazards varied among bays. The greatest hazards occurred in bays that flooded and dried periodically, compared to those that stayed flooded.

- Gravid bass were collected from SRS reservoirs to evaluate the potential for maternal transfer of mercury into fish eggs and resulting larval fish. Mercury concentrations were relatively low in eggs compared to other tissues in the fish. Egg production appears to be a minor route of mercury excretion in adultbass. Mercury in fish accumulates with age via the diet, and the initial contribution by maternal transfer is quite small.

- Tissues from juvenile snowy egrets that were exposed to low or elevated mercury concentrations in their diets were analyzed for stable nitrogen isotopes. These data provide a novel method of assessing protein turnover and allocation of dietary resources in stressed and unstressed animals. Egrets fed the higher mercury diet had higher $\delta{ }^{15} \mathrm{~N}$ ratios in their livers than those fed the low mercury diet. This suggests enhanced rates of protein degradation and synthesis in response to mercury exposure, as well as increased metabolic costs.

- New studies were initiated on the accumulation of mercury in the biota of wetlands constructed for effluent remediation, on the impacts of repeated flooding and drying of sediments on accumulation of mercury and other metals by crayish, and on the effects of chronic mercury exposure in growth, development and metamorphosis of amphibians. 
- Amanuscriptdescribing mercury concentrations in SRS raccoons has been accepted for publication.

- A manuscript has been written that describes the relationship between the concepts of ecological halflife (as used for radioactive contaminants) and "monitored natural attenuation" ( generally used for non-radioactive contaminants). This paper will be published in the proceedings of an International Congress on Radioecology-Ecotoxicology.

\section{Monitoring and Risk Assessment for the Endangered Wood Stork}

Principal Investigators: I. Lehr Brisbin, Jr. and Charles H. Jagoe

To assist the U.S. Department of Energy ( DOE) in their efforts to preserve and manage their natural resources, specifically the federally endangered Wood Stork (Mycteria americana), SREL continued to monitor the SRS for the frequency and location of stork use and to determine contaminant concentrations (primarily mercury) in stork prey. Monitoring efforts focused on active, historical, and potential SRSstork foraging sites ( typically Carolina bays and other bay-like wetlands), including reservoir systems potentially impacted by site management activities. Most "natural" SRS wetlands are not surveyed for contaminants by other site monitoring programs, and this projectprovides comparisons of mercury concentrations in small reservoir fish with similar-sized fish in wetlands ( bays) not thought to receive direct (point-source) pollution. Local stork colonies were monitored for observable contaminant effects and will be a source of tissues to analyze for contaminant detection. Contaminant levels ( mercury) in nestlings from these local stork colonies were compared to levels in nestlings from more distant colonies. SREL has a long-term (6+ year) database concerning mercury levels in stork nestlings to assess potential impacts of region and climate conditions on mercury uptake.

For several years, personnel and other program resources associated with the SREL Wood Stork Program were funded to conduct an in-depth study of the breeding behavior and nesting ecology of the Bald Eagle (Haliaeetus levcocephalus) and the potential risk to this species associated with heavy metal and radionuclide contaminant intake on the SRS. This project has now been completed with the release of a final report ( described in other sections of this report).

- In 2001, Wood Stork use of many SRS wetlands was extremely low, due to the continued impact of the longterm (3+ years) drought that resulted in the complete drying of many of the wetlands that storks use as foraging habitat. A study examining the effects of the drought on fish populations in Carolina bays (summer 2001) indicated a substantial reduction in the number of SRS bays supporting fish populations, and thus a reduction of stork foraging habitat on the SRS.

- In 2001, project personnel published peer-reviewed manuscripts concerning mercury concentrations in nestling Wood Storks, post-fledging (free-ranging) storks, and the prevalence of nocturnal foraging by storks. An additional publication (in press) reports on the potential threats of mercury to storks that forage in SRS depression wetlands.

- Agraduate fellowship has been awarded by the Brazilian government to allow a Brazilian student to come to SREL to conduct doctoral studies comparing the molecular genetics of North American vs. South American Wood Storks.

\section{Ecotoxicology: Environmental Physiology of Sublethal Effects of Trace Element Contamination on Organisms on the SRS}

\section{Principal Investigator: Dr. Justin D. Congdon}

Coal combustion accounts for $90 \%$ of fossil fuel-related wastes produced in the U.S. and constitutes a major category of waste production on the SRS. In D-Area, coal ash is discharged into open settling basins that are located approximately one-quarter mile from the Savannah River. Effluent from the basins enters Beaver Dam Creek, which flows into the river. High levels of trace elementcontamination ( $\mathrm{As}, \mathrm{Cu}, \mathrm{Cr}, \mathrm{Cd}, \mathrm{Se}, \mathrm{Sr}$ ) exist in the water, sediments, and biota in the settling basins and downstream areas. Among the organisms that accumulate trace elements are alligators, softshell turtles, slider turtles, water snakes, largemouth bass, several sunfish species, bullfrogs, toads, crayfish, and freshwater clams. Our research seeks to identify the extent of contamination of organisms inhabiting the D-Area Ash Basins, 
and to help explore less expensive remediation alternatives. The goals of our research are to: (1) identify organisms that have elevated trace element levels and any associated morphological, physiological, and behavioral abnormalities; and (2) identify the amounts and routes of contaminants transferred into nearby terrestrial habitats by birds, mammals, and reptiles. Conditions in D-Area are responsible for the following research findings:

- Previous field surveys (1997-2001) revealed that the frequency of spinal malformations in bullfrog larvae developing in the ash basins ranges from 27-38\%. The frequency of malformations at the polluted site is up to 30 times higher than what is found in reference sites. However, in 2002 the frequency of malformations in the contaminated system decreased to $<1 \%$. More intensive monitoring efforts are being initiated to ascertain what fluctuating environmental variables may be responsible for the observed fluctuations in malformation frequency.

- Body burdens of trace elements in bullfrog larvae differ according to developmental stage and season of capture. Most trace element concentrations decrease in larvae following metamorphosis, suggesting that body burdens of terrestrial recruits are lower than would be predicted based upon larval body burdens. Notable exceptions to these trends are Se and Sr, which increase in concentration following metamorphosis, likely due to sequestration in S and Ca-enriched tissues, respectively.

- Green frog larvae raised on ash accumulate concentrations of Se and As thatare more than an order of magnitude higher than levels in control larvae.

- Green frog larvae raised on ash exhibit reduced growth rates, protracted larval development, and reduced survival through metamorphosis.

- Common grackles breeding in the contaminated site transfer potentially toxic levels of Se to their eggs.

\section{Risk Assessment of Mixed Waste: Synergistic Effects on Individuals and Populations}

Principal Investigators: Justin Congdon, Tom Hinton, and William Hopkins

Processing nuclear materials and other industrial activities such as steam and energy generation have produced mixed wastes at many locations on the Savannah River Site (SRS). Particular categories of waste (i.e., radionuclides such as cesium and strontium, and chemical contaminants such as arsenic, cadmium, mercury, and selenium) can be associated with specific processes or activities. However, once released into the environment, contaminants of various types and from many sources can result in complex mixtures that may create new environmental problems. Assessments of risk to nonhumans associated with environmental contamination often focus on a single type of pollutant, butrisk assessments based on a single stressor may be inadequate to describe the actual threats to individuals or populations. A review of risk assessment within the DOE Environmental Remediation Program, conducted by the National Academy of Sciences, stated: "If DOE or other stakeholders desire greater utility and less potential bias in the risk assessment process, then greater precision, more research, and more data are required [ on] health effects of mixtures of wastes."

The goals of this research program are to: (1) identify sites where synergistic effects of mixed contaminants such as trace elements and radionuclides (cesium and strontium) pose problems for organisms; (2) identify which suites of contaminants are associated with morphological, physiological, behavioral, and genetic abnormalities; and (3) identify the amounts of mixed wastes that cause detectable abnormalities.

- Permits and radiation safety concerns of operating the Low Dose Irradiation Facility ( LoDIF) at the Par Pond Laboratory are being addressed and the facility is now close to operating. LoDIF is an outdoor array of some 50 tanks in which numerous species of aquatic organisms can be subjected to chronic, low-level exposures from radiation, either alone or in combination with other contaminants.

- We obtained over 1000 genetically altered Medaka fish eggs from a colleague, Dr. Richard Winn, at the University of Georgia. Every cell within the tiny fish carries a bacterial gene that serves as a target for DNA damage. We think these fish will be ideal for testing the effects of environmental pollutants. Fish are cheaper to use than lab mice, take up less space, and reproduce faster and in larger numbers, thus creating a larger database for dose-response research.

- An initial pilot study within LoDIF was begun this fiscal year. The experiment is examining the effects of gamma 
irradiation coupled to cadmium exposure on Medaka.

- Two breeding colonies of reptiles have been established for controlled laboratory studies on the interactions of dietary contaminants. Colonies of brown house snakes (Lamprophis fuliginosis) and western fence lizards ( Sceloporus occidentalis) are currently being used to ascertain the effects of dietary selenium on growth, reproduction, and survival. Future studies will be initiated to ascertain how Se interacts with other ingested contaminants.

- Apaper on the conceptual basis for studies of ecological toxicology was published this FY: Congdon, J. D., A. E. Dunham, W. A. Hopkins, C. L. Rowe and T. G. Hinton. 2001. Resource allocation-based life histories: A conceptual basis for studies of ecological toxicology. Environ. Toxicology and Chemistry 20:1698-1703.

\section{Studies of the Fate and Effects of Nuclear Industrial Contaminants in Wildlife of the Savannah River Site: Assessments of Ecological and Human Health Risks}

Principal Investigators: I. Lehr Brisbin, Jr. and Charles H. Jagoe

Concentrations of radiocesium $\left({ }^{137} \mathrm{Cs}\right)$ and non-nuclear contaminants ( particularly mercury and other heavy metals) have been determined in both free-living SRS wildlife and "sentinel animals" released into contaminated SRS habitats. Sentinel animal studies, for example, can be undertaken to study factors controlling the uptake and concentration of these contaminants through controlled/manipulative experimentation using species such as bantam chickens, game farm mallard ducks, and radio-transmitter-equipped box turtles. At the same time, assessments of biomarkers indicative of contaminant impacts upon these animals can be made and this information can then be related to the contaminantbody burdens of the same individuals. This work is focused mainly on species utilizing aquatic food chains of the SRS, particularly those of the Site's abandoned reactor cooling reservoirs (Par Pond, L-Lake, and Pond B). An emphasis is also placed upon game species such as deer and hogs that may be consumed by the public after being harvested on the Site (e.g., during SRSdeer hunts). Concern is also directed toward highly mobile species (e.g., doves, waterfowl) that may become contaminated and then quickly leave the Site and thus serve as potential vectors of SRS contaminants to the public. These studies are designed to provide long-term baseline data of the kind required for both ecological and human health risk assessments for future SRS activities and include basic species ecology, behavior, and movementstudies. Among these activities is the eventual need to consider draining one or more SRS reactor cooling reservoirs, as was proposed as part of the SRS river water shutdown, and the cleanup of contaminated waste sites under Federal Facilities Agreement with the state of South Carolina. Recent advances in the areas of Geographic Information Systems ( GIS) technology, radioecology, molecular genetics, and ecotoxicology are employed. Studies of the basic ecology and natural history of these game species on the SRS, while essential for evaluating the risk to these species from Site contaminants and other activities, also provide information on the status of these populations on the Site. This information is shared in turn with those groups, such as the U.S. Forest Service, which are charged with managing these populations and other natural resources on the site.

- Amanuscript was written describing the patterns of longterm declines in radiocesium levels in SRS biota over the past 30 years. This paper formed the basis for an invited platform presentation at an International Congress on Radioecology-Ecotoxicology, which was held in Aix-en Province, France, in September 2001.

- A manuscript describing the ecological half-life of radiocesium in vegetation of the SRS's Steel Creek swamp delta has been published.

- A manuscript describing the use of raccoons as bioindicators of radiocesium contamination has been accepted for publication.

- A graduate thesis has been completed using radiotelemetry techniques to study the movements of raccoons in the vicinity of radiocesium-contaminated wetland habitats on the SRS; the potential for raccoons to serve as a vector of this radionuclide to the food chain of the off-site hunting public was examined. 


\section{Phytoremediation and Enhanced Monitored Natural Attenuation: Plant-Based Technologies to Remediate Contaminated Soils and Plumes}

Principal Investigators: Domy C. Adriano, Kenneth W. McLeod, Gary Mills, Tracy Punshon, and Lee Newman

Plants can playa major role in remediating and rehabilitating degraded soils and plumes. Various species have been shown to stabilize, filter, and/or extract excess nutrients, organic solvents, metals, and radionuclides. Plant roots can also stabilize and improve soil structure, thereby decreasing erosion. Transpiration by plants will reduce leaching of contaminants to the groundwater by reducing the amount of downward water movement. A favorable microenvironment exists in the plantrhizosphere for fungi and microorganisms to degrade toxic organic compounds and transform inorganic contaminants. This can enhance natural attenuation. Plant-based remediation could be used in situations where contaminant concentration is low, risk to the public is low, and where slower, low-cost cleanup technologies can be substituted for more invasive, immediate, and high-costcleanup. These technologies can be especially appropriate when dealing with buried mixed wastes as plant roots absorb and transform/degrade both organic and inorganic constituents.

Objectives of our research are to: (1) investigate the tolerance and uptake rates of various contaminants by native and economic plant species; (2) explore the suitability of plants to remediate various contaminated soil and/or plume settings directly or indirectly through the production of root exudates that contain low-molecular weight organics and carbohydrates that serve as electron donors or complex with inorganic contaminants, and (3) evaluate the addition of soil amendments in optimizing plant uptake of certain contaminants (e.g., metals and radionuclides).

- Studies of nickel, cadmium, and zinc uptake have been completed for a wide range of hybrid poplars ( Populus spp.), concentrating on those that have been used previously for phytodegradation of trichloroethylene (TCE) . Considerable clonal differences have been shown between clones within the same species, and there is evidence to suggest that their different tolerance abilities may allow them to either facilitate or prevent phytoextraction to meet the needs of the end user. Major findings of this research indicate a clone-specific response to metal uptake, both of metals supplied singly and those supplied in tandem with another metal intended to mimic a mixed waste situation. Hybrid poplar clones differ, often up to an order of magnitude, in the amount of heavy metal they can accumulate before phytotoxicity is observed, confirming the importance of clone selection in plant-based remediation studies. Studies also indicate that heavy metal toxicityencountered at mixed waste contaminated sites- will almost definitely negate phytoremediation processes which involve the transpiration stream, such as the uptake of volatile organic compounds. Studies have shown that phytotoxicity of some clones of trichocarpa $\mathrm{x}$ deltoides (TD) results in retarded growth and almost a complete cessation of the characteristically robust transpiration stream. Comparisons between clones exposed to metals also suggest that TD clones are by no means the most favorable clone choice for use in remediation of toxic metals, and the clones nigra $\mathrm{x}$ maximowczii (NM) and deltoides x nigra (DN) produced more biomass and accumulated more metals than TD clones.

- Screening studies on Paspalum grasses for comparative metal tolerance have also been completed, and have shown that acid-tolerant strains may also have an enhanced ability to tolerate $\mathrm{Ni}$.

- Studies modeling natural attenuation and contaminant bioavailability at Steed Pond indicate that uranium, the main contaminant of concern, is notaccumulating within plant tissues and herbivores, but data strongly suggest that there is considerable migration of $\mathrm{Ni}$.

- Scale-up studies using hybrid poplars and black willow at several waste sites will investigate the phytoremediation of inorganic and organic contaminants using the screened poplars in a variety of contaminated soils. Of particular interest, the phytoremediation project at the C-Area burning rubble pit, where dominant indigenous plant species are being screened to evaluate their uptake potential for TCE and its derivatives, has been initiated. To date, pines and sweetgum tissues (trunk, leaf, root) were collected for chemical analysis. The concurrent occurrence of titrated groundwater should provide a useful tool as tracer to elucidate on the source term and dynamics of the TCE.

- A workgroup, Natural and Enhanced Environmental Remediation (NEER), at SREL has been initiated under 
the leadership of Domy Adriano and Lee Newman. The group has met twice for information purposes among professionals at SREL and discussed means on how to collaborate with other research groups at SRS. In October 2001, a workshop led by Drs. Newman and Adriano on natural remediation process convened at the UGA conference center attracted $100+$ participants from the region.

- Two study sites were established at the Twin Lakes wetland located within the TCE-contaminated groundwater plume originating at the C-Area Burning Rubble Pit (CBRP). TCE and degradation products were determined in leaves and woody tissue collected from native vegetation at both sites to assess the uptake and degradation of contaminants by the native flora. The results of this survey showed uptake of TCE by pines in the distal region of the plume in the riparian zone adjacent to Four Mile Creek and by willow in the Twin Lake wetland. Based on these data, selected native vegetation was removed and replaced with willow saplings to enhance the natural attenuation of TCE via phytoremediation. The TCE uptake and degradation in the planted willow will be monitored during the next year.

- Four varieties of Amaranthus hypochondriacus and one variety of Amaranthus tricolor were found to have unique varietal characteristics in growth and uptake of zinc and copper when grown in soil containing fly ash. Zinc concentration of the leaves was linearly correlated to the soil zinc concentration when the soil concentration was low, but was also affected by soil pH. Maximum leaf zinc concentration was approximately $1400 \mathrm{ppm}$. Leaf copper concentrations were lower by an order of magnitude and not affected by soil pH.

- Fy ash concentrations up to $10 \%$ by weight did not affect the height, leaf weight, or stem weight of two species commonly used in roadside wildflower plots (Joe Pye weed [ Eupatorium purpureum] or Ox-eyed sunflower [Heliopsis helianthoides]) when grown in Blanton, Orangeburg, or Smithboro soils. Only leaf boron concentrations increased with fly ash additions, although concentrations of other elements varied according to soil type.

\section{Aquatic Invertebrates and Trophic Pathways for Contaminants in Pond 4, a Small Abandoned Cooling Reservoir on the SRS}

\author{
Principal Investigator: Barbara E. Taylor
}

Radiocesium has been an important constituent of the contaminants released accidentally from nuclear reactors. An experiment to study its short-term dynamics in a small impoundment was initiated by T.G. Hinton and J.E. Pinder III (A Field Test of the Efficiency of a Biotic System for Remediating Radionuclide and Metal Contamination in Surface Waters, a DOE Center of Excellence project). Intensive, coordinated sampling programs were designed to track transfers among biotic and abiotic components of the system after stable cesium was introduced into the water of the pond on 1 August 1999. We monitored uptake of stable cesium by the snail Helisoma trivolvis and larvae of the insect Chaoborus punctipennis.

Because invertebrates constitute the bulk of the primary consumers in most aquatic systems, they can play an important role in the trophic transfer of contaminants to fish and other secondary consumers. At Pond 4, Chaoborus represents planktonic trophic pathways: it feeds on planktonic microcrustaceans. Helisoma represents littoral trophic pathways: it feeds on epiphytic algae and detritus in the littoral zone. Both species are present year-round, although populations were too low to sample effectively in winter 1999-2000. Our choices of species were based on extensive quarterly sampling in 1998-1999 to quantify abundances of benthic and planktonic invertebrates (beginning March 1998) and to evaluate trophic position of many common taxa using ratios of stable isotopes of carbon and nitrogen (beginning September 1998). Isotope ratios indicated that closely related species might use different trophic resources and that even the same species might use differentresources in different habitats. We thus determined that our inferences about dynamics of cesium would be stronger if we could sample the same species in the same habitats over time. We devised collecting and processing procedures that met this goal and provided biomass sufficient for reliable estimates of the concentration of stable cesium.

The littoral zone encompasses habitats of great structural complexity and intense biological activity. This zone constitutes nearly half of the area of Pond 4. Results from 
summer and fall of year 1 (eight sampling dates) pointed to the importance of littoral processes for the incorporation of cesium into the biota, beginning with the uptake by periphyton. Concentrations of cesium in Helisoma were an order of magnitude greater than those of Chaoborus and five orders of magnitude greater than those of filtered pond water.

The high concentration of cesium in Helisoma relative to Chaoborus was maintained through the warm seasons of the following year ( four sampling dates). Concentrations in both taxa declined by nearly an order of magnitude from the post-addition maxima in August 1999 to August 2000. However, cesium concentrations doubled from spring to summer 2000, suggesting remobilization of cesium, perhaps from sediments under anoxic conditions.

Results from experimental additions of cesium to lakes in Canada and Colorado have also suggested that benthic or littoral processes are important in transfers of cesium. However, in contrast with our results for Pond 4, concentrations of cesium were much higher in planktonic invertebrates than in benthic invertebrates at Pond $B$, another abandoned cooling reservoir on the SRS. The samples at Pond B were collected $\sim 20$ yr after contaminant input ceased. As the results from other samples, including macrophytes, and fish, at Pond 4 become available, we will be able to determine whether the two ponds differ in trophic structure or whether the distribution of cesium in the biota changes over time. 


\section{RADIOECOLOGY}

Four decades of nuclear production have resulted in the releases of radioactive materials into many ecosystems of the United States and Eurasia. There is a need for more detailed information on the fate of radioactive materials and their effects on individual organisms, populations, and communities. Knowledge concerning the effects of low dose-rate radiation is particularly lacking. The need for this information has been cited in reviews by the U.S. Department of Energy ( DOE) and the National Academy of Sciences. Such information is also essential to the new and revised missions of the DOE at the Savannah River Site and elsewhere, and for regulatory programs of various state and federal agencies. The study of radiation in the environment has been a central tenet for Savannah River Ecology Laboratory (SREL) researchers for many years. In its early years SREL was called the Institute for Environmental Radiation, and to this day, SRELremains one of very few academic institutions committed to the discipline of radioecology.

Current directions for radioecological research at the Savannah River Ecology Laboratory address:

- Environmental distribution, uptake, and transport of radioactive contaminants on the SRS, meeting DOE needs for compliance and predictions of risk;

․ Health effects upon nonhumans from mixed wastes;

$\square$ Dose assessments for plants and animals exposed to environmental radiation;

$\square$ Genetic changes in response to previous and current plant operations;

- Assessment of environmental problems associated with radionuclides in the environment;

$\square$ Development of bioindicators as a cost-effective way for assessing risks; and

- International programs in radioecology, for transfer of relevant knowledge to address radiation problems at DOE complexes. 
Environmental Distribution, Uptake, and Transport of Radioactive Contaminants on the Savannah River Site: Meeting DOE Needs for Compliance and Predictions of Risk

Principal Investigators: Thomas G. Hinton, Anna C. Knox, and Rebecca R. Sharitz

The objectives of this research are to help document current radioactive contaminant levels on the Savannah River Site; understand the mechanisms and processes that govern radionuclide transport sufficiently that accurate long-term predictions of contaminant transport and fate can be made with quantifiable certainty; and determine current as well as future human and ecological risks from radioactive contamination. Two studies were conducted during the last year:

(1) In collaboration with Dan Kaplan at SRTC, we conducted a feasibility study for the phytoimmobilization of uranium, thorium, several of their daughter products, mercury, and chromium. These elements are soil contaminants at the TNX Outfall Delta Operable Unit (TNXOU). Based on measurements of the annual biomass of leaves produced and their contaminant concentrations, we estimated the reduction in soil contamination over time due to uptake by the indigenous trees. Deciduous leaves were collected and sorted by tree species from 46 leaf-litter baskets, each $0.18-\mathrm{m}^{2}$ in area. Concentrations of ${ }^{238} \mathrm{U}$ and ${ }^{232} \mathrm{Th}$ were determined from ICPMS analysis of the leaves. An index was developed, termed the Site-Specific Phytoextraction Potential (SPP), that accounts for contaminant concentrations in the soil, the availability of the contaminant to the plant ( based on DTPA extractions), and the plant's annual biomass production. Significant differences among tree species were found, with tupelo (Nyssa sylvatica L. va. biflora) and sweetgum ( Liquidambar styraciflua L) having an order of magnitude greater capacity to remove U and Th from the soil than the other tree species. When the large leaf litter biomass ( 6472 $\pm 944 \mathrm{~kg} \mathrm{ha}^{-1}$ ) of all tree species combined was factored in, the SPP index for composited leaf-litter exceeded that of any individual species we examined. Significantly more U was phytoextracted than Th from the site. Plant uptake of $U$ and Th was generally greater at this site, residing $\geq 88^{\text {th }}$ quantile of values found in the literature. We also gauged phytoremediation success with a risk-based model, RESRAD, in which the ground water pathway was altered to include the process of contaminant removal by phytoextraction.
Computer simulations revealed that the community of native trees currently at the site was not effective at lowering soil concentrations of Uand Th contaminants within a reasonable time period ( $100 \mathrm{yr}$ ). Although trees have been shown to be effective phytoremediation tools for some organic contaminants, we found that the low propensity for plant uptake of $\mathrm{U}$ and Th isotopes precludes their effective use.

Two WSRC reports were issued:

- Kaplan, D. I., A. S. Knox, T. G. Hinton, R. R. Shariz, B. P. Allen, and S. M. Serkiz. 2001. Evaluation of the Phytoimmobilization Technology for the TNX Outfall Delta. WSRC-TR-2001-00032, Rev. 0. Westinghouse Savannah River Company, Aiken, SC.

- Kaplan, D. I., A. S. Knox, T. G. Hinton, R. R. Shariz, B. P. Allen, and S. M. Serkiz. 2001. Proof-of-Concept of the Phytoimmobilization Technology for the TNX Outfall Delta: Status Report. WSRC-TR-2001-00375, Rev. 0. Westinghouse Savannah River Company, Aiken, SC.

An extended abstract was published: Knox, A. S., D. I. Kaplan, and T. G. Hinton. 2001. Remediation of Metals and Radionuclides by Phytoextraction and Sequestration. IN: 6th International Conference on the Biogeochemistry of Trace Elements, Guelph, Ontario, Canada, July 29-Aug. 2, 2001 ( extended abstract).

A manuscript as been submitted: Hinton, T. G., D. Kaplan, A. Knox, and N. Bell. December 2001. Phytoremediation potential of native trees in a uranium and thoriumcontaminated wetland. Submitted to Journal of Environmental Quality.

Several talks and posters were given:

- Hinton, T. G., A. S. Knox, and D. I. Kaplan. In-situ remediation technique for ${ }^{137} \mathrm{Cs}$ contaminated wetlands. Agronomy Society of America's Annual Meeting. Charlotte, NC October 21-25, 2001.

- Kaplan, D. I., A. S. Knox, and T. G. Hinton. Uptake of radionuclides and metals by netted-chain fern. Agronomy Society of America's Annual Meeting. Charlotte, NC October 21-25, 2001.

- Knox, A. S., D. I. Kaplan, and T. G. Hinton. Radionuclide and heavy metal uptake by trees in a contaminated wetland. Agronomy Society of America's Annual Meeting. Charlotte, NC October 21-25, 2001. 
(2) A technique for the in situ remediation of ${ }^{137} \mathrm{Cs}$ contaminated wetlands was field-tested in Pond Aand the Rdischarge canal on the SRS. Replicated limnocorrals were deployed as experimental units and two treatments of illite clay, plus a control, are being used to evaluate the remediation method. Limnocorrals are plastic tubes that isolate a 10-ft. diameter column of water and its associated sediments. The illite amendment is spread on the water surface and settles to the lake bottom, scouring the water of ${ }^{137} \mathrm{Cs}$ as itdescends. The cost of the amendment is a mere $\$ 0.15$ per pound, including shipping from Tennessee. The technique holds promise as a tool for reducing ${ }^{137} \mathrm{Cs}$ bioavailability in contaminated wetlands on the SRS, and in a manner that is not destructive to the environmentas are many other wetland remediation methods. To date, the technique has been very successful at reducing the bioavailability of ${ }^{137} \mathrm{Cs}$. Significant decreases in ${ }^{137} \mathrm{Cs}$ concentrations have been observed in water, duckweed, fish, and water lilies.

Amanuscriptwas published: Hinton, T. G., A. Knox, D. Kaplan, and S. Serkiz. 2001. An in situ method for remediating ${ }^{137} \mathrm{Cs}$ contaminated wetlands using naturally occurring minerals. J. Radioanalytical and Nuclear Chemistry 249:197-202.

A WSRC technical report was prepared: Knox, A. S., T. G. Hinton, and D. I. Kaplan. 2001. Bioavailability of Radioactive Cesium in Old R Discharge Canal, R-Canal, Pond A, and the Adjacent Floodplain. WSRC-TR-2001-00455, Rev. 0. Westinghouse Savannah River Company, Aiken SC.

Several talks and posters were given:

- Hinton, T. G. Nondestructive Remediation of ${ }^{137} \mathrm{Cs}$ Contaminated Wetlands. SREL Natural Monitored Attenuation Symposium, Aiken, SC, 4 October 2001.

- Hinton, T. G., A. S. Knox, and D. I. Kaplan. In-situ remediation technique for ${ }^{137} \mathrm{Cs}$ contaminated wetlands. Agronomy Society of America's Annual Meeting. Charlotte, NC October 21-25, 2001.

\section{Dose Assessments for Plants and Animals Exposed to Environmental Radiation}

Principal Investigators: Thomas G. Hinton, Travis C. Glenn, and Michael H. Smith

Accurate dose assessment is critical for addressing biological effects associated with radiation by way of dose-response relationships. These dose-response relationships apply to a variety of end points, including DNA damage, cellular physiology, fertility, viability, and population/community dynamics. Development of accurate methods for assigning absorbed dose could prove to be very cost effective for cleanup activities on the SRS and other sites. Current tables and mathematical approaches for extrapolating dose from exposure values are usually overly conservative. Knowledge of an actual dose could exempt some regions from cleanup requirements or serve to downgrade polluted areas to lower priority or less stringent control measures. The International Atomic Energy Agency and Department of Energy (DOE) have established the maximum allowable doses for aquatic fauna and flora and terrestrial plants $(10 \mathrm{mGy} / \mathrm{d})$ and terrestrial animals $(1 \mathrm{mGy} / \mathrm{d})$. These regulations create a need for accurate determination of dose accrued through internal and external sources of radiation. A lack of data exists for plant and animal dose rates to determine if regulatory compliance to these guidelines is being met on the SRS or on other DOE and U.S. Department of Defense complexes. Although exposures at many parts of the SRS have been well characterized, the relationship between exposure and absorbed dose is complex and robust methods for dose assessment are in need of development and testing.

- A molecular marker has been successfully developed for assaying the frequency of chromosome damage in turtles. Three manuscripts on the subject were published in 2001 and a fourth one has been submitted:

- Ulsh, B. A., J. D. Congdon, T. G. Hinton, E. W. Whicker, and J. S. Bedford. 2001. Culture methods for turtle lymphocytes. Methods in Cell Science. 22:285-297.

- Ulsh, B. A., F. W. Whicker, T. G. Hinton, J. D. Congdon, and J. S. Bedford. 2001. Chromosome translocations in T. scripta: The dose-rate effect and in vivo lymphocyte radiation response. Radiation Research 155:63.

- Mulhlmann-Diaz, M. C., B. A. Ulsh, F. W. Whicker, 
T. G. Hinton, J. D. Congdon, and J. S. Bedford. 2001. Conservation of chromosome-1 in turtles over 66 million years. Cytogenetics and Cell Genetics 92:285-297.

- Ulsh, B. A, L Dugan, T. G. Hinton, F. W. Whicker, and J. S. Bedford. (in press) Environmental biodosimetry: A biological relevant tool for ecological risk assessment and biomonitoring. Submitted to J. Environ. Radioactivity.

- A new thermolumeniscent dosimeter (TLD) is being tested with our collaborator Jim Abraham at Colorado State University. The small rod shaped TLD is $1 \mathrm{~mm}$ in diameter and $5 \mathrm{~mm}$ long. We have test inserted them under the skin of live Medaka fish. If successful, they will allow us to obtain individual dose-response relationships on our exposed fish in the Low Dose Irradiation Facility.

- An outdoor irradiation facility designed for conducting low-dose experiments is nearing completion. The facility is unlike any in the United States and is a powerful tool for addressing dose-response research.

- A research proposal for $\$ 1.2 \mathrm{M}$ was submitted to the DOE Low-Dose program to study adaptive response and genomic instability using molecular tools, transgenic fish, and SREL's outdoor irradiation facility.

- Research proposals to DOE were also submitted for continuation of dose-response work at Chornobyl.

\section{Genetic Changes in Response to Previous and Current Plant Operations}

Principal Investigators: Travis C. Glenn, Charles H. Jagoe, J Vaun McArthur, Michael H. Smith, and Christopher S. Romanek

Alterations of genetic materials can occur in organisms living in contaminated environments, especially where radionuclides are one component of the total contaminant burden. The primary goal of this research is to test for genetic changes and other associated effects both in single-celled microbes and in complex multicellular organisms living in SRS environments contaminated with radionuclides and heavy metals. Specifically, the following are ongoing: (1) assess and quantify the effects of previous and current plant operations on the genetic structure and function of sentinel species; (2) determine the level of organism exposure to contaminants; ( 3 ) determine the relationships between the effects in organisms and contaminant exposure, and (4) use this information to help DOE in its environmental compliance and remediation efforts. The most basic unit of change is the sequence of the base pairs within DNA strands; however, genetic damage and its effects can occur at scales that range from the gene, through the individual organism, to populations and communities. Thus, we use a variety of techniques to assess genetic damage and effects at several hierarchical scales. The principal techniques we use come from molecular, population and quantitative genetics, phylogenetics, population ecology, radioecology, ecotoxicology, developmental biology, and risk assessment. These techniques are used in both laboratory and field experiments as well as field surveys. The primary focus is on flora and fauna from SRS sites, butwe are increasing activities in the assessment of microbial communities. We also use organisms from elsewhere to provide control or reference sites and an appropriate ecological context to support the generality of our findings (e.g., some of the same biomarkers may be compared in ecologically equivalent species from the SRSand Chornobyl). Thus, our broader goal is to address applied problems with solutions that are based upon a solid theoretical and scientific basis. We are using markers of genetic variation including mitochondrial DNA, anonymous nuclear DNA, and microsatellites as well as measures of DNA damage including strand breakage assessed using pulsed field gel electrophoresis and single cell (also known as "comet") assays. We are comparing measures of genetic variation or DNA damage to traditional measures of contamination (concentrations of radionuclides, heavy metals and/or organics), morphology (e.g., size of skeletal elements, length, weight, and asymmetry), and physical condition (e.g., body fat and presence of tumors). We are examining comparisons within and among wildlife populations and other model organisms to determine the relationships among these variables.

We have completed several tasks during this last year:

- Direct assessment of mutation rate between parents and offspring of American alligator populations from the SRS, coastal South Carolina, and coastal Louisiana was completed. Mutation rates for SRS alligators are not higher than the two reference populations.

- Levels of ${ }^{137} \mathrm{Cs}$ in American alligator eggs and hatchlings from Par Pond, coastal South Carolina, and coastal Louisiana were determined. These results are being 
integrated into a study of radionuclide and heavy metal contaminants and mutation rates among populations of American alligators, focusing on the Par Pond population at the SRS.

- A proposal on the evolutionary mechanisms involved in antibiotic and heavy metal resistance of microbial communities was submitted to $\mathrm{NH}$.

- We have completed studies documenting the utility of using the organismal form for two mammalian species ( white-tailed deer and hispid cotton rats) as a sensitive indicator of environmental effects for both ecological and evolutionary time scales. Because of the relatively low cost of the technique, itcan be applied to large areas over extended time periods to monitor and document environmental changes.

\section{International Programs in Radioecology}

Principal Investigators: Michael H. Smith, Charles H. Jagoe, Travis C. Glenn, and Domy C. Adriano

To complement the long history of radioecology research at the SRS, studies at other sites offer opportunities to determine the distribution and behavior of radionuclides in different environments. Other sites may also offer the opportunity to evaluate the effects of higher radiation doses than those presently occurring at SRS on resident organisms. For example, the areas near the Chornobyl Nuclear Power Plant offer unique opportunities for important investigations that can (1) assist in strategic planning in case of future accidents or releases, (2) assess the effectiveness of cleanup technologies, and (3) evaluate the risks associated with chronic exposure to radiation. SREL scientists have been involved with research at Chornobyl and other sites in the former SovietUnion since 1992 and have developed excellent working relationships with foreign scientists and administrators.

Our efforts to strengthen working relationships with the scientists at Chornobyl have resulted in the establishment of the International Radioecology Laboratory ( IRL) in Slavutych and Chornobyl, Ukraine. The IRL was established by two separate agreements: the Government to Government Agreement signed on 22 July 1998 by then Vice President Gore and Ukrainian President Kuchma and the Agreement between The University of Georgia and the Chornobyl Center for Nuclear Safety, Radioactive Waste, and Radioecology of 15 January 1999. Funds provided by DOE-SR were used to renovate laboratories and purchase research equipmentand furnishings. The facility was dedicated in a ceremony in May 1999 by Deputy Secretary of Energy Glauthier and officially opened in March 2000. The laboratory allows researchers from SREL and other academic institutions in the former Soviet Union, Europe, and the United States to perform field studies in highly contaminated regions of the Chornobyl Zone and to analyze samples in a cost-efficient and coordinated manner. Activities at this laboratory facilitate interchanges of methods, ideas, and technologies from international experts working in the field of environmental radiation, toxicology, biology, and risk assessment. Studies conducted at the IRL will have high relevance for DOE in areas including radioecology, management of contaminated lands, health and ecological risk assessment, and evaluation of remediation technologies.

Major areas of effort have been the initiation of research programs in concert with scientists from The University of Georgia, University of South Carolina, and Texas Tech University, as well as securing funding for the continued operation of the IRL. One project tested the hypothesis that radioactive contamination altered genetic diversity and developmental stability in populations of small mammals in areas near Chornobyl using yellow-necked mice ( Apodemus flavicollis) as a model species. These studies were part of a doctoral dissertation by a native Ukrainian student at SREL (Taras Oleksyk), who completed his degree at UGAin 2001. An ongoing project examines radioactivity, genetic, and morphological variation in plants including Typha latifolia, T. angustifolia and Betula verucosa collected near Chornobyl as well as reference sites. A study of the distribution and effects of radionuclides on plants will be part of a doctoral dissertation of another Ukrainian student at SREL(Olga Tsyusko). A third projectmeasures radioactivity in fish, amphibians and mammals from the Chornobyl area and the SRS to examine the frequency distributions of ${ }^{137} \mathrm{Cs}$ in populations. These frequency distributions are nonnormal, as indicated by strong relationships between standard deviations and means. The shapes of radionuclide frequency distributions are critical to designing appropriate sampling strategies, and in developing risk assessment models. Studies have also been initiated on radionuclide accumulation and effects in amphibians from contaminated wetlands near Chronobyl. 
- A manuscript was published describing the frequency distributions of radiocesium in populations of terrestrial and aquatic animals. The frequency distributions of these contaminants were non-normal and skewed, demonstrating that the highest concentrations and thus the greatest risks are confined to relatively few individuals in each population.

- A manuscript was submitted on radiocesium measurements in several species of amphibians collected near Chornobyl. Frogs of the species Rana terrestris contained nearly twice as much radiocesium as Rana esculenta from the same area; this may reflect differences in diet between the species. Additional samples for genetic analyses have been collected in the past year. 


\section{Centers of}

\section{EXCELLENCE}

The Savannah River Ecology Laboratory (SREL) played a pivotal role in the development of the U.S. Department of Energy-Savannah River Environmental Centers of Excellence Program at the Savannah River Site. Participants in these centers include the Savannah River Ecology Laboratory (SREL), Education, Research and Development Association of Georgia Universities (ERDA), and South Carolina Universities Research and Education Foundation (SCUREF). In 1997 SREL received funding for six collaborative research projects. Project descriptions and accomplishments for programs completed during FY02 are detailed on the following pages. 


\section{Experimental Approach to Constructed Treatment Wetland Design}

Principal Investigators: Rebecca R. Sharitz, Beverly S. Collins, J Vaun McArthur, and Christopher S. Romanek

A constructed treatment wetland (CTW) is often the method of choice to remediate acidic metal-contaminated coal runoff water, such as leachate from coal storage piles and from mine tailings. On the Savannah River Site, coal-pile run-off from the D-Area power plant is collected in a shallow basin (the D-Area Basin) and contaminates shallow groundwater in the area. Water in the D-Area Basin is acidic ( $\mathrm{pH}$ 2.4) and high in dissolved metals including iron $(\mathrm{Fe})$, aluminum (Al), copper $(\mathrm{Cu})$, zinc $(\mathrm{Zn})$, nickel $(\mathrm{N})$, manganese $(\mathrm{Mn})$, and chromium (Cr).

The overall objective of this research was to determine the feasibility of using CTWs to improve the quality of acid-sulfate water such as the drainage from the D-Area basin. Specific goals of the experiment were: (1) to understand the process of acid-sulfate remediation, and (2) to test the effectiveness of wetland substrate, plant community composition, and different microbial assemblages in improving water quality.

An experimental CTW array consisting of 48 continuous flow wetlands was established adjacent to the D-Area basin. Each experimental wetland consisted of three linked mesocosm cells: an anaerobic cell designed to raise the $\mathrm{pH}$ of the water and lower metal concentrations and two aerobic cells designed to further reduce metal concentrations. Thus, in each experimental system, water from the basin flowed first through an anaerobic cell filled with organic substrate and limestone, and then through two aerobic cells representing deep and shallow wetlands. The order of deep and shallow aerobic cells, and their vegetation composition ( planted with native plants, planted with artificial plants to provide substrate for microbial assemblages, not planted) were varied to test site-specific effectiveness of many component combinations. The treatmentbegan in the spring of 1999 and was terminated in the late fall of 2000, following two growing seasons. Major findings included:

- As basin water flowed through the anaerobic mesocosm cells, Al, Fe and Zn were reduced $93-99 \%$. The aerobic tanks further reduced $\mathrm{Al}$ and $\mathrm{Fe}$ by $91-95 \%$ and increased the pH to 7. Aluminum, Fe, Mn, and Zn entered the CRW at $109 \mathrm{mg} / \mathrm{l}, 223 \mathrm{mg} / \mathrm{l}, 6.1 \mathrm{mg} / \mathrm{l}$ and $2.0 \mathrm{mg} / \mathrm{l}$ and exited the system at $0.01 \mathrm{mg} / \mathrm{l}, 1.3 \mathrm{mg} / \mathrm{l}, 2.1 \mathrm{mg} / \mathrm{l}$ and $0.05 \mathrm{mg} / \mathrm{l}$, respectively.

- Concentrations of all metals exceptZn increased in plant tissues over time in the CTWs. Concentrations in plant shoots differed between deep and shallow tanks, with higher $\mathrm{Zn}$, Al, and Fe concentrations in emergentspecies growing in shallow tanks and higher $\mathrm{Na}$ and $\mathrm{Mn}$ concentrations in the shoots of floating species in deep tanks. Root concentrations of most elements differed among species in each tank type.

- Patterns of elemental uptake and concentration in the four native plant species reflect plant life form, element concentrations and interactions in the system, and physiological role of the elements. Over at least two growing seasons, native plants can function as polishing systems in CTWs designed to remediate acidic, metalcontaminated coal runoff.

\section{A Field Test of the Efficiency of a Biotic System for Remediating Radionuclide and Metal Contamination in Surface Waters}

Principal Investigators: Thomas G. Hinton, Barbara Taylor, and Christopher S. Romanek.

An experimental tracer study using stable nonradioactive cesium $\left({ }^{133} \mathrm{Cs}\right)$ additions to an entire pond is nearing completion. The data will yield valuable kinetic transport information on the rate that Cs migrates through aquatic systems. Such data are critical for evaluating the long-term movement of radioactive $\mathrm{Cs}$, and in predicting the associated risks to offsite residents. The data also test the concept of monitored natural attenuation for a radioactive contaminant. We have been routinely sampling water, sediments, plankton, fish, macrophytes, invertebrates, and periphyton to determine the rate the added stable Cs moves from one environmental component to another.

Understanding the processes governing a contaminant's transport is difficult in uncontrolled field experiments; however, controlled laboratory experiments are often contrived and may quickly loose realism. Because knowing how well small-scaled, laboratory experiments mimic those from full-scale field manipulations is of fundamental importance, we compared the loss of cesium from a lake's 
water column atfour differentscales: (1) an 11 ha lake; (2) five, 1.2-m diameter limnocorrals; ( 3) four, 30-cm diameter limnocorrals; and (4) four, 30-cm diameter laboratory mesocolumns. Limnocorrals were installed in 1 to $2 \mathrm{~m}$ of water and at two different areas within an 11 ha lake. All limnocorrals were sealed to the lake sediments, allowed free exchange with the air, but isolated a column of the lake's water. Laboratory mesocolumns were plastic cylinders, closed on one end, and had $15 \mathrm{~cm}$ of sediments placed in them, topped with $90 \mathrm{~cm}$ oflake water. The monomictic lake had a mean and maximum depth of 1.6 and $4 \mathrm{~m}$, respectively. Stable Cs was added to the epilimnion of the whole lake, and to the limnocorrals and mesocolumns. The loss rate of cesium from the water column of each system was compared over time (Table 1). The data are useful for determining how well small-scaled experiments simulate water/sediment exchange processes occurring in whole-lakes.

Our expectations were not confirmed by the results of this experiment. We anticipated that the lake-deployed limnocorrals would more closely mimic the loss rate exhibited in the whole-lake, and that the larger the limnocorral the closer the data would be to that of the whole-lake. The data, however, suggested that retention within the smaller sized experimental units best mimicked the whole-lake, and that there was no difference between the laboratory mesocolumns and the field-deployed small limnocorral. Cs loss from the large units was significantly slower than all the other systems studied, perhaps due to increased $\mathrm{NH}_{4}$ concentrations brought on by fecal material from roosting birds. Overall, the smaller-scaled experimental units mimicked Cs retention in the whole-lake surprisingly well; although, it is possible that the similarity was serendipitous fortuity (i.e. random luck). It is interesting that both the laboratory mesocolumns and the small limnocorrals were of the same $30-\mathrm{cm}$ diameter. It is possible that $\mathrm{Cs}$ retention in these small units is driven by adsorption on to surface walls, and that their surface areas happened to promote a loss rate similar to that of the whole-lake.

Although the data are not convincing enough for us to recommend limnocorrals as a panacea to radioecological investigations in lakes, the data do indicate a real potential for their use under cautious and closely monitored conditions. Their value is in research where treatments or manipulations are applied to test specific hypotheses, and a replicated experimental design permits the use of powerful statistical methods such as ANOVA.

A manuscript describing this research is in press: T. G. Hinton, J. E. Pinder, F. W. Whicker, L. Marsh, J. Joyner, D. Coughlin, Y. Yi, and J. Gariboldi. Comparative kinetics of cesium from whole-lake, limnocorrals and laboratory-scale experiments. IN: ECORAD 2001, Aix-en-Provence, France.

TABIE 1. Linear regression results of Cs retention are shown for the large limnocorrals, small limnocorrals, laboratory mesocolumns, and whole-lake. Retention equations, $\mathrm{R}^{2}$ values, and $95 \%$ confidence intervals about the mean Cs half-time are presented.

\begin{tabular}{|c|c|c|c|c|c|}
\hline Treatment & Retention Equation & $\mathbf{R}^{2}$ & $\begin{array}{c}\text { Mean } \\
\text { T1/2 (d) }\end{array}$ & $\begin{array}{c}\text { Lower 95\% } \\
\text { C.I. (d) }\end{array}$ & $\begin{array}{c}\text { Upper 95\% } \\
\text { C.I. (d) }\end{array}$ \\
\hline Large- LC & $\mathrm{Y}=\ln (5.665)-0.0053 \mathrm{x}$ & 0.90 & 131 & 113 & 158 \\
\hline Small- LC & $\mathrm{Y}=\ln (6.015)-0.0105 \mathrm{x}$ & 0.95 & 66 & 59 & 75 \\
\hline Lab-MC & $\mathrm{Y}=\ln (6.086)-0.0105 \mathrm{x}$ & 0.92 & 66 & 54 & 84 \\
\hline Whole-lake & $\mathrm{Y}=\ln (2.407)-0.0124 \mathrm{x}$ & 0.85 & 56 & 46 & 71 \\
\hline
\end{tabular}




\section{RESEARCH Support}

\section{Programs}

Several SREL programs provide critical support to the research, outreach, and education missions of the Laboratory. These support programs include:

$\square \quad$ National Environmental Research Park Program

Environmental Health \& Safety Program

$\square \quad$ Distance Learning Program

Quality Assurance Program

$\square \quad$ Research Data Archive Activities

$\square$ SREL Undergraduate \& Graduate Education Programs

$\square \quad$ Environmental Outreach \& Education

$\square \quad$ DOE Research Set-Aside Areas 


\section{National Environmental Research Park Program}

\section{Lehr Brisbin, Jr.}

The Savannah River National Environmental Research Park (NERP) is a protected outdoor laboratory for long-term research projects to study the environmental impacts of human activities. Because public access to U.S. Department of Energy (DOE) land is limited, environmental research projects can be carried out on the lands of the Savannah River Site (SRS) with a minimum of interference. The NERP is not simply a site to conduct research, but also should have programs that address the following general objectives: (1) development of methods to assess and monitor the environmental impact of human activities both quantitatively and continually; (2) development of methods to estimate or predict the environmental response to proposed or ongoing site activities; and (3) demonstration of the impact of various activities on the environment and evaluation of methods to minimize adverse impacts. Pursuant to these objectives, it is necessary to supply basic data so that environmental decisions, standards, and monitoring programs can be developed upon a firm ecological and scientific base.

Previously, NERP initiatives changed annually as directed from DOE in Washington, D.C. However, the final disposition of the NERP program has now fallen to local DOE sites because the program is presently not supported nationally by DOE' $S$ Office of Science. In recent years, the SRS NERP program has been supported with funding from within the SREL budget. During the past year, however, for the third year in a row, no funding was available to support specific NERP objectives and activities. Thus, at this pointatleast, the NERP concept at the SRS has become a conceptual framework for the development of environmental research activities on the SRS site lands, but without specific program activities being funded or conducted in this area at this time. A web page that was developed based upon a poster presented at the $50^{\text {th }}$ Biological and Environmental Research (BER) Symposium in 1997 is viewable at http://www.uga.edu/srel/ ESSite/NERPhome.html. A web page about the seven DOE NERP sites is maintained by Oak Ridge National Laboratory and is available at $\underline{h t p}: / / 128.219 .30 .74 /$ index.html.

During the pastyear, although no specific funding was made available for site NERP activities, the SRS NERP Coordinator (I.L Brisbin) continued to make a number of presentations concerning NERP program goals and objectives at the SRS to a number of groups throughout the Southeast. These presentations, which also emphasized the need to eventually introduce congressional legislation officially defining and designating the SRS as a National Environmental Research Park, were made to various groups and, in mostcases, travel expenses associated with those presentations were provided by the groups to whom the presentations were given.

Several of these presentations were made to conferences of various groups of the Presbyterian Church (USA) which, along with the National Council of Churches, has developed a national focus of concern on the issue of global warming. These presentations described the importance of large protected areas of natural habitat as locations for testing critical landscape-level hypotheses concerning carbon sequestration and global warming. The important role that sites such as the SRS NERP could play in national programs of global warming research was clearly emphasized.

A national conference featuring the NERP concept, honoring the late Dixie Lee Ray, was organized by Dr. Alan Moghissi of the Institute of Regulatory Science (RSI). This conference was originally scheduled to be held in October 2001, but was cancelled following the events of September 11; it has now been rescheduled for later in 2002. In the meantime, RSI has formed a national working group to develop and promote NERP concepts and federal NERP legislation for a number of DOE sites across the nation. I.L. Brisbin will serve on the Steering Committee for this group and will represent SRS NERP interests.

\section{Environmental Health and Safety Program}

Warren J. Safter and Donald R. Mosser

The Savannah River Ecology Laboratory ( SREL) has completed its fifth year of operation under the work-smart safety and environmental standards that resulted from SREL's participation in U.S. Department of Energy's ( DOE) Necessary and Sufficient process. These standards appropriately address the hazards associated with SREL operations by permitting a focused effort on the health and safety issues most pertinent to SREL operations.

In an effort to increase the efficiency and effectiveness of the 
Environmental Health and Safety (EH\&S) Program, an emphasis continues to be placed on safetyand environmental training of SREL personnel. It is generally well accepted that a well-trained and educated workforce will result in fewer on-the-job injuries and environmental mishaps. New personnel safety and environmental orientation was presented to 58 individuals. Additionally, training was provided for Chemical Coordinators, hazardous waste workers, and radioactive sealed source users. SREL Environmental Safety Services also sponsored an Identity Fraud Seminar presented by John Pullen of DOE.

On a more informal level of training, the use of SREL's internal computer network to provide targeted information to specific groups in the laboratory and extensive use of World Wide Web and Internet resources brought pertinent information to the attention of SREL personnel. More than 50 lessons learned and health and safety topics were distributed via email throughout the year. Safety training literature is also placed in break rooms and pamphlets are made available in a hallway magazine rack.

Facility inspections remain a cornerstone of the SREL Safety Program. SREL personnel conducted regularly scheduled facility inspections. In addition, SCDHEC conducted an inspection of SREL hazardous waste managementareas. SREL also conducted assessments in the areas of chemical and radiological air emissions, community right-to-know, and the Georgia Right-to-Know law in compliance with state and federal requirements. Safety Services personnel approved more than 400 chemical purchases.

Chemical disposal and waste minimization issues continued to be emphasized to increase efficiency and costeffectiveness. Waste minimization techniques such as source reduction and bench-top treatment as a means of reducing the burden associated with current waste disposal procedures have been incorporated into experimental protocols, providing greater environmental protection while reducing bureaucratic overhead.

SREL disposed of a significant quantity of hazardous and radioactive waste this year. In cooperation with WSRC Solid Waste Division, SREL successfully shipped approximately 100 pounds of mercury wastes and excess laboratory chemicals containing mercury to a mercury-recycling firm. This resulted in the reduction of SREL's chemical inventory of mercury containing chemicals. Additionally, in cooperation with WSRC Solid Waste Division, SREL successfully shipped approximately 900 pounds of excess hazardous laboratory chemicals and laboratory hazardous wastes to a hazardous waste disposal firm ( May 2002).

The SREL Safety Manual has undergone revision to reflect safety protocol for currentactivities. The SREL Safety Services Strategic Plan has also been finalized.

\section{Distance Learning Program}

\section{Laura Janecek}

The Savannah River Ecology Laboratory maintains a stateof-the-art Distance Learning (DL) facility that delivers twoway audio and visual transmissions via a T1 line. The twoclassroom facility is part of the Georgia Statewide Academic and Medical Systems (GSAMS), a cooperative and collaborative distance education network in the state of Georgia with more than 350 interactive audio and videoconference classrooms. This facility gives SREL the capability to communicate with other distance learning users throughout the country. SREL uses DL for classroom instruction for a Master's degree program, other graduate courses, outreach presentations, graduate student committee meetings, faculty meetings, and staff briefings. During the past year, the SREL Distance Learning Program continued to focus its efforts on programming related to SREL core programs in ecology and environmental science and provided almost 300 hours of programming to SREL and SRS personnel. The primary program for SREL is the multidisciplinary Master of Science degree in Environmental Toxicology, offered in cooperation with the UGA School of Pharmacy. This is the first degree offered by UGA through any distance learning site. Five new students are expected to begin the program in the fall of 2002, in addition to five students continuing into the second year of coursework for the degree. Three students have completed all required coursework and are working on the research component of the degree.

The SREL Outreach Program has been using DL technology to extend their programming because theycan reach multiple classrooms as well as minimize travel and animal handling time by using this facility. Outreach personnel presented 14 
lectures on various ecological topics to students in South Carolina and Georgia K-12 schools. Topics included:

- Reptiles and Amphibians of the Southeast

- This Multicolored World

- Keeping Track of Wood Storks

- Life in Wetlands

- Antibiotic Resistant Bacteria

- The Search for Life on Mars

\section{Quality Assurance Program}

Laura Janecek

SREL has continued to maintain a formal, U.S. Department of Energy (DOE) -approved Quality Assurance (QA) program. The program is devoted to assuring the continuing quality of SREL research. During FY02 the written materials describing the SREL QA Program were updated and added to the Laboratory's Intranet website. These SREL "Good Research Practices" highlightresearch concepts and context, research logistics, and the conduct of research. All new Laboratory research personnel are required to familiarize themselves with this material prior to beginning work at SREL

\section{Research Data Archive Activities}

Laura Janecek

Responsible management of research data holdings plays an important role in preserving the SREL's corporate memory. Since 1989, SREL has been actively building a centralized repository of research data files and the associated "metadata" necessary to make these data fully accessible. The goals of SREL's Research Data Archive activityare to avoid the inadvertent loss of data and to use advanced electronic computer/communication technology, including the use of computer networks and the Internet, to provide access to important data as efficiently as possible. Inclusion of new and historical research information into the SREL data archives continued during FYO2 and the Central Archive Data Repository now has information covering over 440 separate studies.

The previous DOS-based SREL data archive system was replaced during FY02 with a web-based system that allows users to upload metadata information and actual data files directly from their office desktop computers. Files are delivered automatically to the SREL server, from which Computer Services personnel upload the information to a Windows-based Microsoft Access relational database. During FY02 all old metadata that did not have associated data files was purged from the SREL data catalog, leaving only those studies for which data exist. Anyone at SREL or on the SRS can search for data using this new web-based system, however decisions about releasing original data to third parties are retained by the principal investigators.

\section{SREL Undergraduate and Graduate Education Program}

\section{J Vaun McArthur}

The objective of the SREL Education Program is to promote professional development and enhance environmental awareness among undergraduate and graduate students through research participation and training programs with emphasis on conducting ecological research important to the Savannah River Site mission. Undergraduate and graduate student participants FY02 are listed in Table 2 (page 44).

The SREL Education Program has averaged 20 undergraduate students per year since 1968. These students, from over 100 different colleges and universities, have been co-authors on $135+$ peer reviewed research publications; more than 100 of these students have gone on to pursue careers in science. The Undergraduate-Research Experience for Undergraduates, funded by the National Science Foundation, sponsored 12 students this year. In addition, we sponsored three students funded by NOAA, two students funded by SREL, and one funded by USC Honor College, Columbia.

Since 1967, an average of six students a year have completed graduate studies at SREL and over 280 dissertations and theses have been written. During FY02 seven students completed their degree requirements ( three M.S. and four Ph.D.). Since 1985, our graduate students have won over 160 awards from regional, national, and international competitions at numerous professional societies and foundations. During the past year, our graduate students continued to compete successfully for various national and regional awards. Some of these are listed in the section on 
Special Accomplishments (page 51).

SREL Graduate Students Completing Degree Requirements:

Jennifer Brofft Ph.D.- University of Georgia, Athens-J Vaun McArthur

Daniel Dawson M.S.-Colorado School of Mines, GoldenJohn Seaman

Susan Dietz M.S.- University of Georgia, Athens- Barbara Taylor

Wouter Geebelen Ph.D.-Limburgs Universitiar Centrum, Belgium- Domy Adriano

Taras Oleksyk Ph.D.- University of Georgia, AthensMichael Smith

Jeffrey Retzke M.S.- Medical University of South Carolina, Charleston- Paul Bertsch

Julie Weston Ph.D.- University of Georgia, Athens-I. Lehr Brisbin

\section{Environmental Outreach and Education}

J. Whittield Gibbons

The Savannah River Ecology Laboratory's missions of research, outreach, and education have resulted in a respected resource in the greater Aiken-Augusta area. The intellectual independence of academic research assures the local community of objective research on the impacts of site operations on ecosystems of the SRS and the region. In addition, the outreach efforts of SREL to the general community have been successful from preschoolers to businessmen. No program exemplifies this better than the herpetology program.

The southeastern United States has the highest biodiversity and abundance of reptile and amphibian species in North America. Because of the rich herpetofaunal biodiversity on the Savannah River Site (SRS), this public land area has been the focus of extensive inventory and research since 1951 and has become the most prolific single site for herpetological research in the world. The SRS is the largest tract of land in North America for which herpetofaunal species abundance, distribution, and diversity have been measured on a long-term basis, resulting in the documentation of more species of herpetofauna $(1,000,000+$ individuals of $100+$ species $)$ than reported from any other public land area in the United States.

SREL uses this information not only to further research efforts, but also to educate the public, both locally and nationally. For, while the goal of currentstudies is to capitalize on this enormous database and continue to add sound data to it, this is not being done in an academic vacuum. The environmental commitments of SREL extend beyond the lab, the SRS, and even the larger local area. Issues as diverse as amphibian and reptile population declines, potential responses (e.g., mutations) of organisms to local contamination, the distribution and abundance of sensitive species, monitored natural attenuation programs, and the dispersal of organisms from radioactively or chemically contaminated sites all are importantbeyond SREL Atno time has this been more clear than in 2002. Based on research and analysis done at SREL, a global trend of reptile declines has been documented and published in the scientific literature.

The SRSis one of the most highly diverse tracts of land in the Upper Coastal Plain as a consequence of long-term environmental protection of native habitats. Studies done here serve to confirm the assumption that environmental health on the SRS is high in comparison to surrounding regions, as well as having direct applicability to the Endangered Species Act, the site initiative of environmental cleanup, and to DOE Land Use and Facilities Management Policies and environmental stewardship. Due to this unique protected environment, ecological research here, especially on the herpetofauna, has taken place under well-controlled conditions and over long periods of time. Recognition for the laboratory's outstanding work has come from many sources.

- SREL has been selected and funded by 10 federal agencies to operate the Partners in Amphibian and Reptile Conservation (PARC) national website (www.parcplace.org), which will serve as the nexus for herpetofaunal databases throughout the country.

- More than 44,000 copies of "Snakes of Georgia and South Carolina" have been distributed, all paid for by outside sponsors in the private sector as well as state and federal agencies.

- The herpetology website (www.uga.edu/srelherp/) continues to be developed and refined. This site has been visited by more than 73,000 viewers and has 


\section{TABLE 2. SREL Undergraduate and Graduate Student Program Participants}

\section{$\underline{\text { Student }}$ \\ Raymond Batts \\ Berkeley Boone \\ Yaniv Brandvain \\ Kenneth Cole \\ Jaclin DuRant \\ Noelle Garvin \\ Matthew Greene \\ Keisha Gregg \\ Bradford Hyman \\ Timothy Maddux \\ Mark Merkley \\ Daniel Moen \\ Carter Pierce \\ Anna Proctor \\ Crista Royal \\ Erica Stanley \\ April Tomkinson \\ Aaron White}

$\begin{array}{ll}\text { Student } & \text { Degree } \\ \text { Kimberly Andrews } & \text { M.S. } \\ \text { Jennifer Broft } & \text { Ph.D. } \\ \text { Elizabeth Burgess } & \text { M.S. } \\ \text { Rebecca Cerajewski } & \text { M.S. } \\ \text { Erin Clark } & \text { M.S. } \\ \text { Daniel Dawson } & \text { M.S. } \\ \text { Susan Dietz } & \text { M.S. } \\ \text { Sara Drake } & \text { M.S. } \\ \text { Luke Fedewa } & \text { M.S. } \\ \text { Bobbi Fokidis } & \text { Ph.D. } \\ \text { Wouter Geebelen } & \text { Ph.D. } \\ \text { Xavier Glaudas } & \text { M.S. } \\ \text { Susanne Hauswaldt } & \text { Ph.D. } \\ \text { Sue Humphries } & \text { M.S. } \\ \text { Jessica Hutchinson } & \text { M.S. } \\ \text { Virginia Jin } & \text { Ph.D. } \\ \text { Lara Katers } & \text { M.S. } \\ \text { Mark Komoroski } & \text { Ph.D. } \\ \text { Yong Jin Lee } & \text { Ph.D. } \\ \text { Audrey Majeske } & \text { M.S. } \\ \text { Liberty Moore } & \text { M.S. } \\ \text { John Mulhouse } & \text { M.S. } \\ \text { Taras Oleksyk } & \text { Ph.D. } \\ \text { Jeffrey Retzke } & \text { M.S. } \\ \text { Elizabeth Richardson } & \text { M.S. } \\ \text { Steven Schaff } & \text { Ph.D. } \\ \text { Pat Shaw-Allen } & \text { Ph.D. } \\ \text { Julian Singer } & \text { M.S. } \\ \text { Robert Thomas } & \text { Ph.D. } \\ \text { Ria Tsaliagos } & \text { M.S. } \\ \text { Olga Tsusko } & \text { Ph.D. } \\ \text { Susan Turner } & \text { Ph.D. } \\ \text { Momin Uddin } & \text { Ph.D. } \\ \text { Laura Uhrich } & \text { M.S. } \\ \text { Jason Unrine } & \text { Ph.D. } \\ \text { Judith Unterkoefler } & \text { Ph.D. } \\ \text { Chelsea Ward } & \text { Ph.D. } \\ \text { Julie Weston } & \text { Ph.D. } \\ \text { Lucas Wilkinson } & \text { M.S. } \\ \text { Christopher Winne } & \text { Ph.D. } \\ \text { Cameron Young } & \text { Ph.D. } \\ \text { Caralyn Zehnder } & \text { Ph.D. }\end{array}$

\section{Undergraduate Research Participation Program}

Academic Institution

Chicago State University, IL

University of Georgia, Athens

College of the Atlantic, ME

Coastal Carolina University, SC

University of South Carolina, Columbia

Erskine College, SC

Auburn University, AL

Claflin University, SC

Clemson University, SC

Clemson University, SC

Brigham Young University, UT

North Dakota State University, Fargo

Clark Atlanta University, GA

Pensacola Christian College, FL

Pensacola Christian College, FL

Clark Atlanta University, GA

University of South Carolina, Aiken

Johnson C. Smith University, NC

\section{Graduate Research Participation Program}

Academic Institution

University of Georgia, Athens

University of Georgia, Athens

University of Georgia, Athens

University of Georgia, Athens

University of Georgia, Athens

Colorado School of Mines, Golden

University of Georgia, Athens

University of Georgia, Athens

University of Georgia, Athens

Arkansas State University, Jonesboro

Limburgs Universitiar Centrum, Belgium

University of Georgia, Athens

University of South Carolina, Columbia

University of South Carolina, Columbia

University of Georgia, Athens

University of Georgia, Athens

Colorado State University, Fort Collins

University of Georgia, Athens

University of Georgia, Athens

University of Georgia, Athens

University of Georgia, Athens

University of Georgia, Athens

University of Georgia, Athens

Medical University of South Carolina, Charleston

University of Georgia, Athens

University of Georgia, Athens

University of Georgia, Athens

University of Georgia, Athens

University of Georgia, Athens

University of Georgia, Athens

University of Georgia, Athens

University of Georgia, Athens

University of Georgia, Athens

University of Georgia, Athens

University of Georgia, Athens

University of Agricultural Sciences, Austria

Auburn University, AL

University of Georgia, Athens

University of Georgia, Athens

University of Georgia, Athens

University of Georgia, Athens

University of Georgia, Athens
Faculty Advisor(s)

Charles Jagoe and Christopher Romanek

J. Whitfield Gibbons

Beverly Collins

Christopher Romanek and Travis Glenn

Lee Newman

Gary Mills

J. Whitfield Gibbons

J Vaun McArthur

I. Lehr Brisbin

John Seaman

J Vaun McArthur

J. Whitfield Gibbons

John Seaman

Beverly Collins

Michael Smith

John Seaman

Barbara Taylor

Charles Jagoe and Travis Glenn

Faculty Advisor

J. Whitfield Gibbons

J Vaun McArthur

J Vaun McArthur

Christopher Romanek

J. Whitfield Gibbons

John Seaman

Barbara Taylor

Beverly Collins

J. Whitfield Gibbons

Travis Glenn

Domy Adriano

J. Whitfield Gibbons

Travis Glenn

Travis Glenn

John Seaman

Rebecca Sharitz

Thomas Hinton

Justin Congdon

Christopher Romanek

Charles Jagoe

I. Lehr Brisbin

Rebecca Sharitz

Michael Smith

Paul Bertsch

J Vaun McArthur

Kenneth McLeod

Charles Jagoe

John Seaman

Christopher Romanek

J. Whitfield Gibbons

Michael Smith

Rebecca Sharitz

Gary Mills

Rebecca Sharitz

Charles Jagoe

Domy Adriano

Justin Congdon

I. Lehr Brisbin

J. Whitfield Gibbons

J. Whitfield Gibbons

J. Whitfield Gibbons

William Hopkins 
generated numerous queries from interested individuals.

- The monitoring of Rainbow Bay reptiles and amphibians continued for its 24th year, as recommended by the SRS Citizens Advisory Board.

- Increased demand for Outreach speakers have required greater use of the Distance Learning Facility.

The Outreach Program is designed to enhance SREL's overall mission of acquiring and communicating environmental knowledge and addresses the U.S. Department of Energy's (DOE) current focus on environmental issues. Some of the ways this is accomplished include the following:

- School groups enjoy field trips to the Laboratory's Conference Center and speakers from SREL go to schools, presenting programs on conservation, the process of science, and environmental stewardship.

- Teachers are trained in methods of teaching ecology during workshops and leave with materials produced by the Outreach staff.

- Speakers from SREL are in such demand that the SREL Distance Learning Facility has been pressed into service to serve more classrooms.

- An internal laboratory newsletter, The GrapeVine, is distributed electronically.

- During the pastyear, SREL scheduled 320 talks, 30 tours, 27 exhibits, and 53 workshops, for a total of 41,871 people reached. Topics for these presentations included biodiversity, the process of science, animal adaptation, plants and wetlands, chemistry and environmental science, local ecosystems and conservation, classification, and careers in ecology and research. The education functions of the lab have been consolidated within the outreach group.

- Over 20,000 copies of the SREL publication An Amphibian's Eye View of Wetlands have been distributed through SREL's Outreach Program, the National Audubon Society's Wetlands Campaign, and Peace Frog's Clothing Company.

- The Outreach program has received recognition from the Council for the Advancement and Support of Education and individuals within the program have been honored by the states of Georgia and South Carolina as well as by various local school districts and national organizations for their outreach efforts.
Outreach programs include "Ecotalk," an opportunity for students to have nature brought into their classroom for a face-to-face lesson on a variety of live animals found in local habitats. These presentations, offered in schools, emphasize hands-on scientific learning using activities in the environmental sciences. "Ecologist for a Day" visits allow students to spend the day in the field gaining "hands-on" knowledge of the plants and animals of the unique Upper Three Runs Creek area. Participants get an opportunity to work with SREL researchers catching, marking, and measuring various species of reptiles, amphibians, small mammals, and invertebrates. In addition, the Outreach Program offers tours of SREL facilities and surrounding field sites, as well as exhibits and workshops for the general public. A27-minute six-projector automated slide presentation about the history of the SRS and SREL research continues to be a regular part of SREL tours.

Thousands of copies of educational products and materials are distributed nationwide to schools, organizations, and the general public. Educational materials include two six-footlong full-color posters describing the importance of wetlands to reptiles and amphibians, along with teachers' guides, and the Outdoor Classroom Planning Guide. The full-color brochure Snakes of Georgia and South Carolina has proved to be an extremely successful educational product that reflects positively on DOE and the SRS. In the four years since its publication, its popularity has grown and necessitated three printings; demand for the book has grown as additional sponsors support and distribute it to their constituencies. The book has been placed at no charge in every public library in Georgia and South Carolina and is also widely distributed at no cost to hospital emergency rooms, veterinary clinics, ambulance services, classrooms, scout leaders, and to various other organizations such as the Boys and Girls Clubs in Aiken and Augusta. Articles referencing the book have appeared in numerous newspapers and magazines including publications in Forida and Texas.

Other Outreach publications include fliers on Carnivorous Plants and Their Habitats and An Amphibian's Eye View of Wetlands, produced in cooperation with Peace Frogs clothing company and the National Audubon Society; a children's comic book entitled Stepping into Ecology: the Ecological Adventures of Mud E. Boot, produced in cooperation with the Medical University of South Carolina's Environmental Biosciences Program; a flier on Isit a Water 
Moccasin? produced in partnership with the Georgia Department of Natural Resources Nongame-Endangered Wildlife Program; and an emergency services calendar that depicts animals, plants, and habitats of the SRS, produced in cooperation with Westinghouse Savannah River Company. As part of a new outreach initiative in chemistry and environmental science, a large sticker with the slogan "Chemistry - its all about the nature of things" was produced and is given to all students who participate in the classroom and workshop programs in this new subjectarea. All of these products have been extremely popular and thousands of copies have been distributed during the past year.

The Outreach Program also continues to produce and distribute various other publications, including Outdoor Classroom Planning Guide, Biodiversity: Prospect \& Promise for the Savannah River Site, and The National Environmental Research Park at Savannah River Site: Serving an Essential Mission for 25 Years. The Outdoor Classroom Planning Guide gives instructions for setting up a variety of outdoor classroom stations and outlines activities and investigations that teachers can use to guide students through hands-on learning experiences in natural settings. The biodiversity brochure highlights the Site's vast natural resources, explains biodiversity in general, and defines its various types, such as genetic diversity. The National Environmental Research Park (NERP) brochure highlights 25 years of research associated with the NERP program at the Savannah River Site. Full-color fact sheets and research "snapshots" on a wide variety of research topics are published and distributed as well

The public relations component of the Outreach Program includes the distribution of news releases on a variety of topics to selected media affiliates, officials of DOE, and The University of Georgia. Included among these has been coverage of SREL research by CNN, U.S. News and World Report, New York Times, Associated Press, BioScience, Earth Magazine, National Wildlife Magazine, National Public Radio, Our World, Atlanta Journal \& Constitution, Weekly Reader, Los Angeles Times, National Geographic, Audubon, Smithsonian Magazine, The Washington Post, Fox News, and more. The Pubic Relations office screens mostinquiries from the press, directing reporters to the mosthelpful researchers for their stories. In addition, SREL initiates press contacts, such as the annual Eco-Calendar, postings on Newswise, and regular submissions to popular magazines, resulting in stories and new contacts with the media including stories in Reptile Life, The World \& I, and Environmental News Network. Regular mentions in UGA publications are also sought.

Outreach also has promoted various research projects through coverage in local and national media and has worked to enhance the laboratory's internal communications. Participation in the CSRA Environmental Consortium has provided the opportunity to showcase SREL at Augusta's Fort Discovery Science Museum and also has provided an opportunity for speakers from the Lab to address groups at Fort Discovery.

\section{DOE Research Set-Aside Areas}

\section{Charles E. Davis}

The Savannah River Site (SRS) is a National Environmental Research Park (NERP) and its large land area and controlled public access provide a diverse and protected outdoor laboratory where researchers study the environmental impacts of the SRS's industrial and forest management operations. Because these studies are usually long-term, they require relatively undisturbed areas as "control" sites where reference, baseline data can be obtained. Known as Research Set-Aside Areas, these reference sites have been withdrawn from the SRS's commercial forest and set aside by the Department of Energy (DOE) primarily for non-manipulative ecological research and educational outreach activities. These areas also serve as "reserve" areas that represent excellent examples of both the typical and unique plant communities indigenous to the SRS while providing critical habitat for the Site's threatened, endangered, or sensitive (TES) flora and fauna. Inclusion in the Set-Aside Program ensures that these areas will be preserved and protected, aids in the maintenance of a high degree of biological diversity on the SRS, and enables DOE-Savannah River to meet the objectives of the National Environmental Research Park (NERP) Program. Currently, there are 30 Set-Aside Areas on the SRS that collectively account for approximately 14,100 acres ( $5,706 \mathrm{ha})$, or $7 \%$ of the Site. Individually, they range in size from 10 acres ( $4.05 \mathrm{ha})$ to 7,400 acres ( $2.995 \mathrm{ha}$ ), and are located in 43 of the Site's 89 timber resource compartments. There are approximately 270 miles ( $168 \mathrm{~km})$ of posted boundaryline associated with these Set-Aside Areas. 


\section{SREL's Set-Aside Program}

The DOE Set-Aside Program is administered by SREL and is overseen by a six-member Set-Aside Task Group composed of natural resource experts from SREL, the South Carolina Department of Natural Resources ( SCDNR), the United States Forest Service-Savannah River (USFS-SR), Westinghouse Savannah River Company (WSRC), and DOE-SR. In 1993, a Set-Aside Protection and Management Plan for the SRS was written by SREL and the USFS-SR to provide general guidance to SREL and the Set-Aside Task Group to manage the SetAside Areas. To date, this plan has been successfully implemented by SREL primarily because the Task Group has been able to resolve land use conflicts and because the SRS's Site-Use Permitting System has been effective in preventing impacts to Set-Asides. The Set-Aside Areas are permitted under SREL's Site-Use Permits SU-79-74-R and SU-89-58-R, and any potential land use or research conflict with a SetAside Area is normally addressed and resolved using this system. In FY02, SREL's Set-Aside Program experienced some changes as the Set-Aside Research Coordinator began working half-time with the Set-Aside program and an SREL faculty member became Chairperson of the Set-Aside Task Group. In addition, SREL's Set-Aside Research Coordinator is no longer is SREL's Site-Use Coordinator, ecolitter cleanup coordinator, or representative to the SRS Pesticide Task Group.

\section{Maintenance of the Set-Aside Areas}

Periodic inspections of Set-Aside boundarypostings continue to be conducted by SREL where potential land-use conflicts are anticipated. SREL and the USFS-SR continue to verify/ update Set-Aside boundary lines that are concordant with the boundaries of prescribed forest stand treatments. Based on these boundary line updates, SREL routinely maintains and updates a Set-Aside GIS boundary data layer, which is made available as a working coverage to USFS-SR timber and GIS personnel for timber stand updating. To date, a significant portion of the original version of the boundary layer coverage has been modified as the result of the USFSSR and SREL GPSing timber sale and Set-Aside boundaries. Atotal of 10 Set-Aside Areas have been GPSd and a significant portion of the E. P. Odum Wetland Set-Aside, as well as others, have been completed. A newer version of the Set-Aside GIS boundary data layer was scheduled to be released to the general site in FYO2 but this was not accomplished; however, the metadata for this coverage were updated and released. In addition, the USFS-SR's seasonal prescribed burning program is coordinated with SREL for Set-Aside protection and permanent fire lines have been established around a number of Set-Aside Areas to reduce this coordination effort. However, this fire line construction is being re-evaluated and currently is on hold as a result of the USFS-SR using larger than anticipated equipment to plow fire lines. Also, SREL and the USFS-FS continually monitor any potential pine beetle problems in Set-Aside Areas and also coordinate for nuisance animal control. The USFS-SR cleared the encroaching vegetation on the right-of-way that crosses through Ellenton Bay this year.

\section{Management of the Research Set-Aside Areas}

SREL is directed to prepare stewardship management plans for each of the 30 Set-Aside Areas, and SREL's Set-Aside Research Coordinator is responsible for developing, writing, and implementing these plans. Because of this responsibility, this person continued to serve as SREL's Interdisciplinary (ID) Team representative to the USFS-SR's timber compartment prescription review process where SREL has input to the development of natural resource management plans for the commercial forest. This coordination and planning with the USFS-SR is successful in verifying Set-Aside and timber stand boundary line concordance with GIS coverages, updating TES population surveys conducted in Set-Aside Areas, and in addressing potential conflicts with forestry activities adjacent to Set-Asides and SREL research areas. USFS-SR timber management plans continue to focus on developing management prescriptions for the Site's subwatersheds, and these plans may include restoring historical plant communities in addition to the traditional pine silvicultural prescriptions and wildlife habitat improvement treatments for the Red-cockaded Woodpecker. Because these treatments to the commercial forest are prescribed over a ten-year period, it is logistically preferred that management plans be developed for Set-Aside Areas in those timber compartments scheduled for prescription renewal so that prescribed treatments to the commercial forest and the Set-Aside Areas can occur simultaneously. These 10-year plans are generally developed by a core team of individuals from various Site organizations and, when necessary, researchers with individual expertise or with a long-term research interest in a Set-Aside may be requested to participate as core team members. Each Set-Aside Area 
management plan has its own assumptions, guidelines, and desired future conditions and each Area's plan addresses both general long-term management objectives and specific management strategies that dictate treatments to the Area's vegetation. Additional management considerations are addressed, including TES flora and fauna, boundary line and road maintenance, fire suppression, and clean-up of research sites. As these natural resource plans are formulated, SREL and USFS-SR negotiate possible administrative land exchanges ( trades in some cases) so that unique and under-represented habitats can be expanded or included in the Set-Aside Program.

During the past year, SREL worked on the development of management plans for four Set-Aside Areas, three of which were completed: the Society of American Forester's ( SAF) Boiling Springs and Scrub Oak Natural Areas (Area Nos. 18 and 29) and the Loblolly Forest Set-Aside (Area No. 4). As part of the Area No. 18 plan, the remaining old growth component and original plot markers were GPSd for future research and documentation. In addition, GIS mapping was begun for a proposed thinning as part of the development of management plans for the Rainbow Bay Amphibian Research Area. All Set-Aside management plans are being developed using SREL's 1999 habitatmap, in which the Area's vegetation component is based on remote sensing and image analysis and classification. As part of the USFS-SR ID team's observations and recommendations to the prescriptions of the Meyers Branch watershed compartments, the Meyers Branch/Ruth Patrick Set-Aside acquired two pine stands that were inaccessible for harvesting. The Ginger's Bay Set-Aside experienced impacts from a severe hail storm this spring and will be monitored for insects. The 30 -acre pine thinning treatment in the Flamingo Bay Set-Aside still awaits marking for sale to begin implementation of this Set-Aside's management plan. This delay is the result of market demands and USFS-SR sales administration oversight. In FY02, discussions continued as part of the conservation easement agreement between Chem Nuclear and DOE, with the intention that USFS-SR and SREL would work together to develop a fire management plan for the Chem Nuclear portion of Craig Pond. SREL and the USFS-SR met on the ground with Chem Nuclear to ensure that no impacts to research in the Craig Pond Set-Aside would occur but, unfortunately, there were two unplanned wildfires in the Craig Pond SetAside that greatly altered the vegetation in the Set-Aside. As a result, future vegetation management options have been compromised and research has been minimally impacted. Due to fire-caused mortality to timber, salvage operations in this Set-Aside may be considered. In addition, there will also be ongoing rehabilitation efforts for fire lines that were put in to control the fires. The burning of Craig Pond and the fact that many of the Carolina Bay Set-Asides are completely dry due to prolonged drought has sparked interest among some SREL researchers to burn Steel Creek Bayand Ellenton Bay. A small 2-acre section of the Old UGA Lab Set-Aside was turned over to the USFS-SR to manage for sand pine regeneration and a general understory treatment. Finally, as a result of DOE security measures related to 9-11, SREL has lost convenient access to five Set-Asides.

\section{Research in Set-Aside Areas}

Researchers from SREL continued numerous long-term plant and animal studies in Set-Asides, including aquatic macro invertebrate studies in Upper Three Runs Creek, a genetics study examining variation over a small mammal species' range, daily amphibian population monitoring at Rainbow Bay, continued use of animals from Risher Pond and Ginger's Bay as controls for D-Area studies, monitoring of turtle nesting and predation, studies of the reproductive behavior of frogs, and an amphibian monitoring program based on calls at Ellenton Bay. In addition, Carolina bay Set-Asides continue to be used as proxies in studies of the hydrology of man-made catchment basins; these studies will support future efforts to remediate such basins. Plantstudies continue to examine the physiology of scrub oak species in the sandhills and resource heterogeneity of plants in old-fields. Also, several wetland plant and seed bank characterization studies in Set-Asides were concluded and published this fiscal year.

Other studies that were initiated or continued this fiscal year in Set-Asides included trophic transfer of heavy metals, dispersal of amphibians from an ephemeral wetland ( Ginger's Bay), and the use of a number of Set-Asides for a study of soil nitrogen and plant organic uptake. In addition, a study was initiated examining the effects of forest management practices on seed production and seedling recruitment. Also, the Sandhills Set-Aside is being used to study the temporal changes in a sandhills herpetofaunal community.

Groups other than SREL also use the Set-Aside Areas. SRTC 
continued to use organisms collected in Set-Asides as "controls" to test methods of evaluating remediation and restoration actions as well as the development of terrestrial bioassessment protocols at DOE sites. Archeologists with the USC-Savannah River Archaeologist Research Program continued to conduct archaeological investigations around Set-Aside Carolina bays. In cooperative efforts, SREL and USFS-SR researchers continue to study coarse woody debris decomposition, softmast production in bottomland hardwood forests, and the role of fleshy fruit production, consumption, and dispersal on promoting biological diversity. Data from long-term studies in Set-Aside Carolina bays continues to be used to help manage and protect these unique wetlands. In addition, the USFS-SR and SREL continued to use Set-Aside Areas in their environmental education and outreach programs. The South Carolina Wildlife Federation hosted a field trip for its members to visit SREL facilities and several Set-Aside Areas on the SRS.

\section{Additional resource management efforts}

During the pastyear, SREL's Set-Aside Research Coordinator continued updating draft data layers of depressional wetlands and drainage ditches on the SRS. These GISlayers are based on interpretations of overflight photography that show these wetlands historically ( 1951 pre-SRS and drained) and then filled during an El Nino event in 1998. These updates will help determine historical wetland hydrology impacts and be valuable for future bay restoration projects. While they have not been officially released, these GIS products are used by the USFS-SR and SREL for wetland restoration decisions and for developing resource compartment prescriptions. In addition, this data layer will aid in improving future released versions of SREL's SRS Bays coverage.

As part of the recommendations for managing SREL's Conference Center property, boundary lines were posted with signs and permanent fire lines were established by the USFSSR for wildfire protection. SREL coordinated with the USFSSR to prescribe burn one of the stands on the property to reduce fuel load and the potential for destructive wildfire; however, due to persistent drought conditions, the prescribed burn did not occur this year. During a USFS-SR prescribed fire on the boundary of the property, a small wildfire occurred within the Conference Center property but was suppressed immediately.

\section{FY02 SREL documents, publications, theses, and dissertations that used DOE Set-Aside Areas}

Although the Set-Aside Program is no longer able to support student research grants, 25 documents were published this year that used habitats or organisms associated with SetAsides. Based on SREL's list of publications, 16 of the SetAside Areas had recent published research associated with them this fiscal year.

Boring, C. S. 2002. Home range, habitat use, and radiocesium burdens of raccoons inhabiting the U. S. Department of Energy's Savannah River Site. M.S. thesis. Rutgers University, New Brunswick, New Jersey.

Brooks, M. J., B. E. Taylor, P. A. Stone, and L. R. Gardner. 2001. Pleistocene encroachment of the Wateree River sand sheet into Big Bay on the Middle Coastal Plain of South Carolina. Southeastern Geology 40:241-257.

Buhlmann, K. A. and G. Coffman. 2001. Fire ant predation of turtle nests and implications for the strategy of delayed emergence. The Journal of the Elisha Mitchell Scientific Society 117:94-100.

Buhlmann, K. A. and J. W. Gibbons. 2001. Terrestrial habitat use by aquatic turtles from a seasonally fluctuating wetland: implications for wetland conservation boundaries. Chelonian Conservation and Biology. 4:115-127.

Burger, J.C., G. Lord, E. J. Yurkow, L. McGrath, K.F Gaines, I.L. Brisbin Jr., and M. Gochfield. 2000. Metals and metallothionein in the liver of raccoons: utility for environmental assessment and monitoring. Journal of Toxicology and Environmental Health. PartA, 60:243-261.

Davis, C. E. 2002. Society of American Foresters' Boiling Springs and Scrub Oak Natural Areas: Stewardship Management Plans for DOE Research Set-Aside Areas 18 and 29 located on the Savannah River Site. Savannah River Ecology Laboratory. Aiken, South Carolina.

Davis, C. E. 2002. Loblolly Pine Forest: Stewardship management plan for DOE Research Set-Aside Areas 4 located in USFSSR Resource Compartment 23. Savannah River Ecology Laboratory. Aiken, South Carolina.

Collins, B. S. and L. L. Battaglia. 2001. Hydrology effects on propagule bank expression and vegetation in six Carolina bays. Community Ecology 2:21-33.

Dietz, S. E., D. P. Batzer, B. E. Taylor, and A. E. DeBiase. 2001. Invertebrate communities of twenty ditched Carolina bay wetlands scheduled for restoration. p. 321-324. In Proceedings of the 2001 Georgia Water Resources Conference, edited by K J. Hatcher, Institute of Ecology, The University of Georgia, Athens, GA. 
Gibbons, J. W. and K. A. Buhlmann. 2001. Reptiles and amphibians. p. 372-390. In Wildlife of Southern Forests: Habitatand Management, edited byJ. G. Dickson. Hancock House Publishers, Surrey, British Columbia and Blaine, WA.

Gibbons, J. W. and M. E. Dorcas. 2002. Defensive behavior of cottonmouths (Agkistrodon piscivorus) toward humans. Copeia 4:195-198.

Hopkins, W. A., J. H. Roe, J. W. Snodgrass, B. P. Jackson, D. E. Kling, C. L. Rowe, and J. D. Congdon. 2001. Nondestructive indices of trace element exposure in squamate reptiles. Environmental Pollution 115:1-7.

Hopkins, W.A., J. H. Roe, J.W. Snodgrass, B. P Staub, and J.D. Congdon. 2002. Effects of chronic dietary exposure to trace elements on banded water snakes (Nerodia fasciata). Environmental Toxicology and Chemistry. 21: 906-913.

Kandl, K. L. 2001. Effects of inbreeding and salinity stress on population dynamics of eastern mosquitofish. Transactions of the American Fisheries Society 130:1224-1232.

Kennamer, R. A. 2001. Relating climatological patterns to wetland conditions and wood duck production in the southeastern Atlantic coastal plain. Wildlife Society Bulletin 29:1193-1205.

Komoroski, M. J. and J. D. Congdon. 2001. Scaling of nonpolar lipids with ovum size in the mole salamander, Ambystoma talpoideum. Journal of Herpetology 35:517-521.

Minahan, K, G. L. Mills, S. Hayden, and J. W. Gibbons. 2002. An assessment of hydrocarbon contamination derived from roofing material coverboards. Herpetological Review 33:36-38.

Mills, G. L, J Vaun McArthur, C. Wolfe, J. M. Aho, and R. B. Rader. 2001. Changes in fatty acid and hydrocarbon composition of leaves during decomposition in a southeastern blackwater stream. Arch. Hydrobiol. 152:315-328.

Oli, M. K, G. R. Hepp, and R. A. Kennamer. 2002. Fitness consequences of delayed maturity in female wood ducks. Evolutionary Ecology Research. 4:563-576.

Penick, D. N., J. Congdon, J. R. Spotila, and J. B. Williams. 2002. Microclimates and energetic of free-living box turtles, (Terrapene carolina), in South Carolina. Physiological and Biochemical Zoology 75(1): 57-65.

Rowe, C. L., W. A. Hopkins, C. Zehnder, and J. D. Congdon. 2001. Metabolic costs incurred bycrayfish (Procambarus acutus) in a trace element-polluted habitat: further evidence of similar responses among diverse taxonomic groups. Comparative Biochemistry and Physiology Part C 129:275-283

Rowe, C. L, W. A. Hopkins, and J. D. Congdon. 2001. Integrating individual-based indices of contaminant effects: How multiple sublethal effects mayultimately reduce amphibian recruitment from a contaminated breeding site. The Scientific World 1:703-712.

Ryan, T. J. and G. Swenson. 2001. Does sex influence postreproductive metamorphosis in Ambystoma talpoideum? Journal of Herpetology 35:697-700.

Sever, D.M., R. A. Stevens, T. J. Ryan, and W. C. Hamlett. 2002. Ultrastructure of the reproductive system of the Black Swamp Snake ( Seminatrix pygmaea). III. Sexual segment of the male kidney. Journal of Morphology 252:238-254.

Wohl, D. L. and J V. McArthur. 2001. Aquatic actinomycetefungal interactions and their effects on organic matter decomposition: A microcosm study. Microbial Ecology 42:446-457. 


\section{Special Accomplishments of Faculty, Staff, and Administration}

\section{Honors and Awards}

Robert Thomas was selected as the winner of the 2002 American Society of Mining and Reclamation Memorial Scholarship at the Ph.D. level. The ASMR scholarship included a \$500 cash award, a \$250 travel allowance for attendance at the 2002 National Meeting in Lexington, $\mathrm{KY}$ in June, a plaque, a one-year student membership, and complimentary national meeting registration and an awards luncheon ticket.

Warren Safter, SREL Environmental Health and Safety Manager, was awarded the prestigious Distinguished Service to Safety Award ( DSSA) by the National Safety Council at their annual convention in Atlanta in September, 2001. The DSSA award is the highestindividual honor that the National Safety Council can bestow on members of its Divisions.

Dr. Domy Adriano of SREL and Jack Mason, owner of Mason's Tree \& Turf Farm in Beech Island, were awarded Patent No. US6,287,358 B1 for "Coal Ash as Soil Amendment to Enhance Water Balance, Growth, and Harvesting of Turfgrasses." This is only the second patent ever awarded to an SREL researcher.

Drs. Machelle Wilson, Steve Harper, and William Hopkins joined SREL as new faculty members in FY02. Machelle Wilson works in ecological data analysis, Steve Harper in spatial informatics, and Bill Hopkins in ecotoxicology.

Drs. Rebecca Sharitz, Steve Harper, Beverly Collins, Whit Gibbons, and John Dilustro and Research Technician Tracy Tuberville of SREL, along with Don Imm, James Westervelt, and Kurt Buhlmann, received a DoD SERDP grant in spring 2002. The project, entitled “ Impacts of Military Training and Land Management on Threatened and Endangered Species in the Southeastern Fall Line/ Sandhills Community," was funded for 4 years at $\$ 940,000$.

Dr. J. Whitfield Gibbons was selected by The Citizens for Nuclear Technology Awareness (CNTA) as the 2001 recipient of CNTA's Distinguished Scientist Award. The award was presented on November 12, 2001 as part of the Teller Lecture program. Gibbons is the first SREL scientist to receive this prestigious award.

Dr. Tom Hinton received an award from the National Association of Environmental Professionals (NAEP). The NAEP has selected DOE's "Graded Approach for Evaluating Radiation Doses to Aquatic and Terrestrial Biota" for a National Environmental Excellence Award.

Dr. J Vaun McArthur was appointed to a National Research Council Committee on Indicators of Water-Borne Pathogens.

Dr. Paul Bertsch was selected to participate on a National EPA Task Force to develop criteria for Natural Attenuation of Inorganic Contaminants.

Dr. Justin Congdon and his work with Michigan turtles was featured in the June 2002 issue of Discover magazine. The article detailed Congdon's discovery that some turtle species appear not to deteriorate physically with age.

Drs. Tom Hinton of SREL and Dan Kaplan of SRTC were featured in a two-minute SRS video and poster that described their joint work on remediating cesium in R-Canal through the addition of illite clay, which sequesters the cesium and allows it to decay in place without becoming bioavailable.

Dr. Domy Adriano is the principal investigator on a $\$ 45,450$ grant from the National Science Foundation to conductinternational workshops on natural attenuation of metals along the Tisza River floodplain-wetlands continuum in Hungary. As part of this program, Hungarian scientists will visitAthens and SREL this summer; American participants will travel to Hungary in the fall.

Virginia Jin received a National Science Foundation grant to participate in the 2002 NSFKorea Science and Engineering Foundation Summer Research Program for U.S. Graduate Students in Korea. 
Dr. Bonjun Koo, a Postdoctoral Fellow at SREL, has been elected as the Secretary and Treasurer of the Korean Association of Agricultural Scientists in North America (KAASA) for the 2001-2003 period.

Erin Clark was inducted into the Forestry, Agriculture, and Veterinary Honor Society (Gamma Sigma Delta) in April 2002. Erin is a graduate student of Dr. Whit Gibbons.

Dr. Christopher Romanek was selected to attend an international conference on Thermophiles in Hot Spring Environments, held at Yellowstone National Park, WY.

SREL's 50 years of ecological research and environmental outreach were featured in an article in the June/ July 2001 issue of Augusta Magazine. The article showcased the SRS and discussed SREL's 50-year history on the site. Research from each of the Laboratory's four research groups was highlighted, as well as the activities of the Outreach Program. The article also featured color photographs by David Scott.

SREL was also featured in an article in USAToday in August, 2001. The article, which discussed the SRS, was highlighted by a photo of SREL's veteran alligator "Stumpy."

Lisa Davis, a University of South Carolina graduate student advised by Dr. Travis Glenn, was awarded the Kathryn Hinnant-Johnson M.D. Memorial Award in Genetics for 2002. She received the award in April at USC.

Susanne Hauswaldt, also a student of Dr. Travis Glenn, received the award for beststudentpresentation at the Marine Science retreat at the Baruch Institute.

SREL was selected as a "featured lab" by HMS Beagle, the BioMedNet magazine. In being named a featured site, SREL joined such prestigious labs as the Sullivan Laboratory at Scripps Research Institute, the Hoy Laboratory at Cornell University, the Draper LaboratoryatJohn Hopkins University, and the Gerstein Laboratory at Yale University.

Dr. Paul Bertsch was invited to serve on a Review Committee for the William R. Wiley Environmental Molecular Sciences Laboratory (EMSL) in Richland, WA, in November 2001.

Dr. I. Lehr Brisbin was interviewed by Peter Jennings of
ABCNews for an upcoming television presentation on values and character in America. The show is expected to air in September 2002.

Dr. John Seaman was invited to serve on a U.S. Army Corps of Engineers scientific proposal review panel for the Project BT25-Environmental Quality Basic Research.

Dr. Brian Jackson was invited to join the editorial board of the journal Water, Air, and Soil Pollution.

Dr. Domy Adriano was recognized as the founder and first president of the International Conference of Biogeochemistry of Trace Elements (ICOBTE) and the International Society of Trace Element Biogeochemistry (ISTEB), respectively, during the banquet of the 6th ICOBTE in Ontario, Canada, in August 2001.

Dr. Whit Gibbons' research programs and the SREL Outreach Program were featured in programs shown this pastyear on the Discovery Channel and National Geographic. 


\section{Externally Funded Grants}

\begin{tabular}{|c|c|}
\hline PI & Paul M. Bertsch \\
\hline Project Title & $\begin{array}{l}\text { Metal Toxicity Reduction by in situ Stabilization: Enhancing Intrinsic Bioremediation of Chlorinated } \\
\text { Hydrocarbons }\end{array}$ \\
\hline Funding Agency & U.S. Department of Energy/Office of Science \\
\hline Budget & $\$ 503,633$ \\
\hline Period & $9 / 15 / 98-6 / 30 / 02$ \\
\hline PI & Paul M. Bertsch \\
\hline Project Title & The Environmental Fate of Arsenic from Poultry Litter \\
\hline Funding Agency & U.S. Department of Agriculture \\
\hline Budget & $\$ 164,500$ \\
\hline Period & $12 / 1 / 00-11 / 30 / 03$ \\
\hline PI & Paul M. Bertsch \\
\hline Project Title & $\begin{array}{l}\text { Effects of Compounds and Colloids on Partition Coefficients for Radionuclides and other Inorganic } \\
\text { Compounds }\end{array}$ \\
\hline Funding Agency & U.S. Environmental Protection Agency \\
\hline Budget & $\$ 100,000$ \\
\hline Period & $7 / 1 / 02-6 / 30 / 03$ \\
\hline PI & Paul M. Bertsch \\
\hline Project Title & $\begin{array}{l}\text { U.S.- France Cooperative Research: Speciation and Formation Mechanisms of Iron and Silicon Associations } \\
\text { in Natural Media }\end{array}$ \\
\hline Funding Agency & National Science Foundation \\
\hline Budget & $\$ 15,600$ \\
\hline Period & $6 / 1 / 99-10 / 31 / 02$ \\
\hline PI & I. Lehr Brisbin \\
\hline Project Title & Studies of Clapper Rails in Coastal Marshes \\
\hline Funding Agency & Savannah Presbytery M.K. Pentecost Ecology Fund \\
\hline Budget & $\$ 6,000$ \\
\hline Period & $6 / 1 / 01-5 / 31 / 02$ \\
\hline PI & I. Lehr Brisbin \\
\hline Project Title & $\begin{array}{l}\text { Aerial Surveys of Birds at the Constructed Wetlands Project and Merryland Ponds, and Ground-Based } \\
\text { Bird-Movement Surveys at the Augusta Regional Airport at Bush Field and the Constructed Wetlands } \\
\text { Project }\end{array}$ \\
\hline Funding Agency & Augusta-Richmond County Consolidated Government \\
\hline Budget & $\$ 64,763$ \\
\hline Period & $8 / 1 / 01-9 / 30 / 02$ \\
\hline PI & I. Lehr Brisbin \\
\hline Project Title & Monitoring Coastal Wood Stork Colonies: Breeding Success and Nestling Mercury Concentrations \\
\hline Funding Agency & U.S. Department of the Interior/Fish \& Wildlife Service \\
\hline Budget & $\$ 34,271$ \\
\hline Period & $9 / 1 / 00-12 / 31 / 02$ \\
\hline
\end{tabular}


PI

Project Title

Funding Agency

Budget

Period

PI

Project Title

Funding Agency

Budget

Period

PI

Project Title

Funding Agency

Budget

Period

PI

Project Title

Funding Agency

Budget

Period

PI

Project Title

Funding Agency

Budget

Period

PI

Project Title

Funding Agency

Budget

Period

PI

Project Title

Funding Agency

Budget

Period

PI

Project Title

Funding Agency

Budget

Period
I. Lehr Brisbin

A Study to Evaluate Bird-Strike Hazards to Aircraft Operations at the Aiken Airport

Southeastern Environmental Solutions, Inc.

$\$ 21,518$

$10 / 1 / 00-6 / 30 / 02$

Beverly Collins

Thresholds of Disturbance: Land Management Effects on Vegetation and Nitrogen Dynamics

Strategic Environmental Research and Development Program (SERDP)

$\$ 1,331,765$

$1 / 1 / 00-12 / 30 / 04$

J. Whitfield Gibbons, William Hopkins, and Travis Ryan

Sublethal Effects of Pesticide Exposure

U.S. Golf Association

$\$ 28,700$

$2 / 1 / 01-5 / 31 / 02$

J. Whitfield Gibbons

Amphibian and Reptile Inventory of Sumter National Forest

U.S. Department of Agriculture/Forest Service

$\$ 20,000$

$9 / 18 / 01-9 / 30 / 04$

J. Whitfield Gibbons

Inventory and Monitor Webster's Salamander on the Long Cane Ranger District of the Sumter National Forest

U.S. Department of Agriculture/Forest Service

$\$ 8,000$

$6 / 6 / 01-4 / 30 / 03$

J. Whitfield Gibbons

Development, Production, and Distribution of Environmental Education Materials for Indigo Snake Protection and Hognose Snake Research

U.S. Department of the Interior/Fish \& Wildlife Service

$\$ 85,900$

$5 / 1 / 01-9 / 30 / 05$

J. Whitfield Gibbons

Research and Development of a Conservation Plan for Establishment of a Reproductive, Self-Sustaining Population of Gopher Tortoises at the Aiken Gopher Heritage Preserve

South Carolina Department of Natural Resources

$\$ 9,992$

9/19/00-6/30/02

J. Whitfield Gibbons

Inventory Report for the Southeastern Coastal Network

U.S. Department of the Interior/National Park Service

$\$ 229,291$

$4 / 1 / 01-9 / 30 / 02$ 
PI

Project Title

Funding Agency

Budget

Period

PI

Project Title

Funding Agency

Budget

Period

PI

Project Title

Funding Agency

Budget

Period

PI

Project Title

Funding Agency

Budget

Period

PI

Project Title

Funding Agency

Budget

Period

PI

Project Title

Funding Agency

Budget

Period

PI

Project Title

Funding Agency

Budget

Period
J. Whitfield Gibbons

Development of Habitat Guidelines for Herpetofauna

U.S. Department of Agriculture/Forest Service

$\$ 60,000$

$8 / 28 / 00-9 / 30 / 02$

William Hopkins

Modeling the Individual and Interactive Risks to an Amphibian Population Resulting from Breeding Site Contamination and Terrestrial Habitat Loss

U.S. Environmental Protection Agency/University of Maryland

$\$ 68,730$

12/19/01-12/18/03

Charles Jagoe

REU: the Impact of Energy Technologies on Natural Environmental Systems

National Science Foundation

$\$ 64,600$

$5 / 1 / 02-4 / 30 / 03$

Christopher Romanek

Controlled Growth of Biologic and Abiotic Carbonates and Fe-oxides

National Aeronautics and Space Administration

$\$ 30,000$

$5 / 14 / 99-11 / 13 / 02$

Rebecca R. Sharitz

Creation of a Geographic Information System Program Plan for the Congaree Swamp National Monument and a GIS Metadata Program for the National Parks in the Southeast Coastal Network

U.S. Department of the Interior/National Park Service

$\$ 61,213$

$11 / 1 / 00-11 / 1 / 02$

Rebecca R. Sharitz

Dissertation Research: Plant Organic Nitrogen Uptake in Temperate Terrestrial Ecosystems

National Science Foundation

$\$ 7,231$

$7 / 1 / 01-6 / 30 / 03$

Rebecca R. Sharitz

Impacts of Military Training and Land Management on Threatened and Endangered Species in the Southeastern Fall Line/Sandhills Community

Strategic Environmental Research and Development Program ( SERDP)

$\$ 939,523$

2002-2005 


\section{Publications}

\section{Journal Articles and Book Chapters Published}

2532

Congdon, J. D., R. D. Nagle, O. M. Kinney, and R. C. van Loben Sels. 2001. Hypotheses of aging in a long-lived vertebrate, Blanding's turtle (Emydoidea blandingii) . Experimental Gerontology 36:813-827.

2533 Albers, P. H., D. J. Hoffman, and I. L. Brisbin, Jr. 2001 Unusual leg malformations in screech owls from a South Carolina superfund site. Journal of Toxicology and Environmental Health Part A. 63:89-99.

2534

Bertsch, P. B. and D. B. Hunter. 2001. Applications of synchrotron-based x-ray microprobes. Chemical Reviews 101:1809-1842.

2535 DeWoody, J. A., D. E. Fletcher, S. D. Wilkins, W. S. Nelson, and J. C. Avise. 2000. Genetic monogamy and biparental care in an externally fertilizing fish, the largemouth bass (Micropterus salmoides). Proceedings of the Royal Society of London B 267:24312437.

2536 Jin, V. L, L. T. West, B. L. Haines, and C. J. Peterson. 2000. P retention in tropical pre-montane soils across forest-pasture interfaces. Soil Science 165:881-889.

2537 Checa, A. G. and A. Rodríguez-Navarro. 2001. Geometrical and cyrstallographic constraints determine the self-organization of shell microstructures in Unionidae (Bivalvia, Mollusca). Proceeding R. Soc. London B 268:771-778.

2538 Hinton, T. G., A. Knox, D. Kaplan, and S. Serkiz. 2001. An in situ method of remediating ${ }^{137} \mathrm{Cs}$-contaminated wetlands using naturally occurring minerals. Journal of Radioanalytical and Nuclear Chemistry 249:197-202.

2539 Gariboldi, J. C., A. L. Bryan, Jr., and C. H. Jagoe. 2001. Annual and regional variation in mercury concentrations in wood stork nestlings. Environmental Toxicology \& Chemistry 20:1551-1556.

2540 Bryan, A. L, Jr., J. W. Snodgrass, J. R. Robinette, J. L. Daly, and I. L. Brisbin, Jr. 2001. Nocturnal activities of post-breeding wood storks. The Auk 118:508-513.

2541 Brown, M. C. L., S. Guttman, and T. C. Glenn. 2001.
Development and use of microsatellite DNA loci for genetic ecotoxicological studies of the fathead minnow (Pimephales promelas). Ecotoxicology 10:233-238.

2542

Buhlmann, K. A. and G. Coffman. 2001. Fire ant predation of turtle nests and implications for the strategy of delayed emergence. The Journal of the Elisha Mitchell Scientific Society 117:94-100.

Jenssen, T. A., M. B. Lovern, and J. D. Congdon. 2001. Field-testing the protandry-based mating system for the lizard, Anolis carolinensis: does the model organism have the rightmodel?Behavioral Ecology \& Sociobiology 50:162-172.

2544 Collins, B. S. and L. L. Battaglia. 2001. Hydrology effects on propagule bank expression and vegetation in six Carolina bays. Community Ecology 2:21-33.

2545 Rowe, C. L., W. A. Hopkins, C. Zehnder, and J. D. Congdon. 2001. Metabolic costs incurred by crayfish (Procambarus acutus) in a trace element-polluted habitat: further evidence of similar responses among diverse taxonomic groups. Comparative Biochemistry and Physiology Part C 129:275-283.

2546 Dietz, S. E., D. P. Batzer, B. E. Taylor, and A. E. DeBiase. 2001. Invertebrate communities of twenty ditched Carolina bay wetlands scheduled for restoration. p. 321324. In Proceedings of the 2001 Georgia Water Resources Conference, edited by K. J. Hatcher, Institute of Ecology, The University of Georgia, Athens, GA.

2547 Seaman, J. C., T. Meehan, and P. M. Bertsch. 2001. Immobilization of cesium-137 and uranium in contaminated sediments using soil amendments. Journal of Environmental Quality 30:1206-1213.

2548 Metts, B. 2001. Ambystoma Maculatum (Spotted salamander). Reproduction. Herpetological Review 32:98-99.

2549 Congdon, J. D., A. E. Dunham, W. A. Hopkins, C. L. Rowe, and T. G. Hinton. 2001. Resource allocationbased life histories: A conceptual basis for studies of ecological toxicology. Environmental Toxicology and 
Chemistry 20:1698-1703.

2550 Bryan, A. L, Jr., C. H. Jagoe, H. A. Brant, J. C. Gariboldi, and G. R. Masson. 2001. Mercury concentrations in post-fledging wood storks. Waterbirds 24:277-281.

2551 Doelsch, E., A. Masion, J. Rose, W. E. E. Stone, J. Y. Bottero, and P. M. Bertsch. 2001. Crystal chemistry of colloids obtained by hydrolysis of Fe(III) in the presence of $\mathrm{SiO}_{4}$ ligands. Materials Research Society 658:GG3.36.1-GG3.36.5.

2552 Masion, A., E. Doelsch, J. Rose, S. Moustier, J. Y. Bottero, and P. M. Bertsch. 2001. Speciation and crystal chemistry of iron( III) chloride hydrolyzed in the presence of $\mathrm{SiO}_{4}$ ligands. 3. Semilocal scale structure of the aggregates. Langmuir 17:4753-4757.

2553 Burger, J., K. F. Gaines, and M. Gochfeld. 2001. Ethnic differences in risk from mercury among Savannah River fishermen. Risk Analysis 21:533-544.

2554 Chesser, R. K, B. E. Rodgers, J. K. Wickliffe, S. Gaschak, I. Chizhevsky, C. J. Phillips, and R. J. Baker. 2001. Accumulation of ${ }^{137}$ cesium and ${ }^{90}$ strontium from abiotic and biotic sources in rodents at Chornobyl, Ukraine. Environmental Toxicology and Chemistry 20:19271935.

2555 Rose, J., I. Moulin, J. L. Hazemann, A. Masion, P. M. Bertsch, J. Y. Bottero, F. Mosnier, and C. Haehnel. 2000. X-ray absorption spectroscopy study of immobilization processes for heavy metals in calcium silicate hydrates: 1. Case of lead. Langmuir 16:9900-9906.

2556 Rose, J., I. Moulin, A. Masion, P. M. Bertsch, M. R. Wiesner, J. Y. Bottero, F. Mosnier, and C. Haehnel. 2001. $\mathrm{X}$-ray absorption spectroscopy study of immobilization processes for heavy metals in calcium silicate hydrates. 2. Zinc. Langmuir 17:3658-3665.

2557 Lee, J. R. and M. S. Mills. 2000. Design and construction of an outdoor enclosure for the study of snake thermal ecology. Herpetological Review 31:24-26.

2558 Kandl, K. L, H. P. Liu, R. S. Butler, W. R. Hoeh, and M. Mulvey. 2001. A genetic approach to resolving taxonomic ambiguity among Pleurobema (Bivalvia: unionidae) of the eastern GulfCoast. Malacologia 43:87101.
2559 Hopkins, W. A., J. H. Roe, J. W. Snodgrass, B. P. Jackson, D. E. Kling, C. L Rowe, and J. D. Congdon. 2001. Nondestructive indices of trace element exposure in squamate reptiles. Environmental Pollution 115:1-7.

2560 Komoroski, M. J. and J. D. Congdon. 2001. Scaling of nonpolar lipids with ovum size in the mole salamander, Ambystoma talpoideum. Journal of Herpetology 35:517-521.

2561 Ulsh, B. A., J. D. Congdon, T. G. Hinton, F. W. Whicker, and J. S. Bedford. 2001. Culture methods for turtle lymphocytes. Methods in Cell Science 22:285-297.

2562 Burger, J., K. F. Gaines, J. D. Peles, W. L. Stephens, Jr., C. S. Boring, I. L Brisbin, Jr., J. Snodgrass, A. L. Bryan, Jr., M. H. Smith, and M. Gochfeld. 2001. Radiocesium in fish from the Savannah River and Steel Creek: Potential food chain exposure to the public. Risk Analysis 21:545-559.

2563 Mills, G. L, J Vaun McArthur, C. Wolfe, J. M. Aho, and R. B. Rader. 2001. Changes in fatty acid and hydrocarbon composition of leaves during decomposition in a southeastern blackwater stream. Arch. Hydrobiol. 152:315-328.

2564 McLeod, K. W., M. R. Reed, and E. A. Nelson. 2001. Influence of a willow canopy on tree seedling establishment for wetland restoration. Wetlands 21:395402.

2565 Komoroski, M. J. 2001. Incidental cache use by the brown thrasher, with notes on secondary cache use by additional avian species. The Chat 65:68-70.

2566 Jiménez-López, C., E. Caballero, F. J. Huertas, and C. S. Romanek. 2001. Chemical, mineralogical and isotope behavior, and phase transformation during the precipitation of calcium carbonate minerals from intermediate ionic solution at $25^{\circ} \mathrm{C}$. Geochimica et Cosmochimica Acta 65:3219-3231.

2567 Kandl, K. L. 2001. Effects of inbreeding and salinity stress on population dynamics of eastern mosquitofish. Transactions of the American Fisheries Society 130:1224-1232.

2568 Brooks, M. J., B. E. Taylor, P. A. Stone, and L. R. Gardner. 2001. Pleistocene encroachment of the Wateree River sand sheet into Big Bay on the Middle Coastal Plain of 
South Carolina. Southeastern Geology 40:241-257.

2569 Rowe, C. L., W. A. Hopkins, and J. D. Congdon. 2001. Integrating individual-based indices of contaminant effects: How multiple sublethal effects may ultimately reduce amphibian recruitment from a contaminated breeding site. The Scientific World 1:703-712.

2570 Ryan, T. J. and G. Swenson. 2001. Does sex influence postreproductive metamorphosis in Ambystoma talpoideum? Journal of Herpetology 35:697-700.

2571 Jackson, B. P. and P. M. Bertsch. 2001. Determination of arsenic speciation in poultry wastes by IC-ICP-MS. Environmental Science \& Technology 35:4868-4873.

2572 Collins, B., G. Wein, and T. Philippi. 2001. Effects of disturbance intensity and frequency on early old-field succession. Journal of Vegetation Science 12:721-728.

2573 Buhlmann, K. A. 2001. A biological inventory of eight caves in northwestern Georgia with conservation implications. Journal of Cave and Karst Studies 63: 9198.

2574 Davis, L. M., T. C. Glenn, R.M. Elsey, I.L. Brisbin, Jr., W.E. Rhodes, H.C. Dessauer, and R.H. Sawyer. 2000. Genetic structure of six populations of American alligators: a microsatellite analysis. Crocodilian Biology and Evolution: 38-50.

2575 Malek, M. A., T. G. Hinton, and S.B. Webb. 2002. A comparison of ${ }^{90} \mathrm{Sr}$ and ${ }^{137} \mathrm{Cs}$ uptake in plants via three pathways at two Chernobyl-contaminated sites. Journal of Environmental Radioactivity 58:129-141.

2576 Kennamer, R. A. 2001. Relating climatological patterns to wetland conditions and wood duck production in the southeastern Atlantic coastal plain. Wildlife Society Bulletin 29:1193-1205.

2577 Gaiser, E. E., B. E. Taylor, and M. J. Brooks 2001. Establishment of wetlands on the southeastern Atlantic Coastal Plain: paleolimnological evidence of a midholocene hydrologic threshold from a South Carolina pond. Journal of Paleolimnology 26:373-391.

2578 Vulava, V. M., E. B. Perry, C. S. Romanek, and J. C. Seaman 2002. Dissolved gases as partitioning tracers for determination of hydrogeological parameters. Environmental Science Technology 36:254-262.
2579

Gibbons, J. W. and K. A. Buhlmann. 2001. Reptiles and amphibians. p. 372-390. In Wildlife of Southern Forests: Habitat and Management, edited by J. G. Dickson. Hancock House Publishers, Surrey, British Columbia and Blaine, WA.

2580 Collins, B. S. and L L Battaglia. 2002. Microenvironmental heterogeneity and Qercus michauxii regeneration in experimental gaps. Forest Ecology and Management 155:279-290.

2581 Peles, J. D., M. H. Smith, and I. L. Brisbin, Jr. 2002. Ecological half-life of ${ }^{137} \mathrm{Cs}$ in plants associated with a contaminated stream. Journal of Environmental Radioactivity 59:169-178.

2582 Duff, M. C., M. Newville, D. B. Hunter, S. R. Sutton, I. R. Triay, D. T. Vaniman, P. M. Bertsch, P. Eng, and M. L Rivers. 2001. Heterogeneous plutonium sorption on Yucca mountain tuff. p. 18-21. In APSForefront, edited by G. K. Shenoy. Argonne National Laboratory, Argonne, IL.

2583 Gibbons, J. W. and M. E. Dorcas. 2002. Defensive behavior of cottonmouths (Agkistrodon piscivorus) toward humans. Copeia 4:195-198.

2584 Wohl, D. L. and J V. McArthur. 2001. Aquatic actinomycete-fungal interactions and their effects on organic matter decomposition: A microcosm study. Microbial Ecology 42:446-457.

2585 Tucker, A. D., J. W. Gibbons, and J. L Greene. 2001. Estimates of adult survival and migration for diamondback terrapins: conservation insight from local extirpation within a metapopulation. Canadian Journal of Zoology 79:2199-2209.

2586 Ishak, C. F., J. C. Seaman, W. P. Miller, and M. Sumner. 2002. Contaminant mobility in soils amended with fly ash and flue-gas gypsum: intact soil cores and repacked columns. p. 287-305. In Water, Air, \& Soil Pollution, edited byJ. Trevors and B. McCormac, Kluwer Academic Publishers, The Netherlands.

2587 Buhlmann, K. A. and J. W. Gibbons. 2001. Terrestrial habitat use by aquatic turtles from a seasonally fluctuating wetland: implications for wetland conservation boundaries. Chelonian Conservation and Biology 4:115-127. 
2588 Andrus, C. F. T., D. E. Crowe, D. H. Sandweiss, E. J. Reitz, and C. S. Romanek. 2002. Otolith $\delta^{18} 0$ record of mid-holocene sea surface temperatures in Peru. Science 295:1508-1511.

2589 Hopkins, W. A., J. W. Snodgrass, J. H. Roe, B. P. Staub, B. P. Jackson, and J. D. Congdon. 2001. Effects of food ration on survival and sublethal responses of lake chubsuckers (Erimyzon sucetta) exposed to coal combustion wastes. Aquatic Toxicology 57:191-202.

2590 Conner, W. H., I. Mihalia, and J. Wolfe. 2002. Tree community structure and changes from 1987 to 1999 in three Louisiana and three South Carolina forested wetlands. Wetlands 22:58-70.

2591 Oli, M. K, G. R. Hepp, and R. A. Kennamer. 2002. Fitness consequences of delayed maturity in female wood ducks. Evolutionary Ecology Research 4:563-576.

2592 Schnurr, J. L., R. S. Ostfeld, and C. D. Canham. 2002. Direct and indirect effects of masting on rodent populations and tree seed survival. OIKOS 96:402-410.

2593 Tidd, S. T., J. E. Pinder, III., and G. W. Ferguson. 2001. Deforestation and habitatloss for the malagasy flat-tailed tortoise from 1963 through 1993. Chelonian Conservation and Biology 4:59-65.

2594 Gibbons, J. W., J. E. Lovich, A. D. Tucker, N. N. FitzSimmons, and J. L. Greene. 2001. Demographic and ecological factors affecting conservation and management of the diamondback terrapin ( Malaclemys terrapin) in South Carolina. Chelonian Conservation and Biology 4:66-74.

2595 Tuberville, T. D. and M. E. Dorcas. 2001. Winter survey of a gopher tortoise population in South Carolina. Chelonian Conservation and Biology 4:182-186.

2596 Conner, W. H., K. W. McLeod, and E. Colodney. 2002. Restoration methods for deepwater swamps. p. 38-42. In Proceedings of a conference on Sustainability of Wetlands and Water Resources: How Well Can Riverine Wetlands Continue to Support Society into the 21st Century? edited by M. Holland, M. Warren, and J. Stanturf, Gen. Tech. Rep. SRS-50. Asheville, NC: U.S. Department of Agriculture, Forest Service, Southern Research Station 191 p.
Peles, J. R. Purdue, 0. V. Tsyusko, 0. 0. Zalissky, and M. H. Smith. 2002. Frequency distributions of ${ }^{137} \mathrm{Cs}$ in fish and mammal populations. Journal of Environmental Radioactivity 61:55-74.

2598 Glenn,T. C., J. E. Thompson, B. M. Ballard, J. A. Roberson, and J. O. French. 2000. Mitochondrial DNA variation among wintering midcontinent gulf coast sandhill cranes. Journal of Wildlife Management 66:339-348.

2599 Hopkins, W. A. J. H. Roe, J. W. Snodgrass, B. P. Staub, B. P. Jackson, and J. D. Congdon. 2002. Effects of chronic dietary exposure to trace elements on banded water snakes (Nerodia fasciata). Environmental Toxicology and Chemistry 21:906-913.

2600 Sever, D. M., R. A. Stevens, T. J. Ryan, and W. C. Hamlett. 2002. Ultrastructure of the reproductive system of the black swamp snake ( Seminatrix pygaea). III. Sexual segment of the male kidney. Journal of Morphology 252:238-254.

2601 Burger, J., C. G. Lord, E. J. Yurkow, and L. McGrath. 2000. Metals and metallothionein in the liver of raccoons: utility for environmental assessment and monitoring. Journal of Toxicology and Environmental Health Part A, 60:243-261.

2602 Penick, D. N., J. Congdon, J. R. Spotila, and J. B. Williams. 2002. Microclimates and energetics of freeliving box turtles, Terrapene carolina, in South Carolina. Physiological and Biochemical Zoology 75:57-65.

2603 Minahan, K, G. L. Mills, S. Hayden, and J. W. Gibbons. 2002. An assessment of hydrocarbon contamination derived from roofing material coverboards. Herpetological Review 33:36-38.

2604 Jones, K. L., T. C. Glenn, R. C. Lacy, J. R. Pierce, N. Unruh, C. M. Mirande, and F. Chavez-Ramirez. 2002. Refining the whooping crane studbook by incorporating microsatellite DNA and leg-banding analyses. Conservation Biology 16:789-799.

2605 Guerin, M. and J. Seaman. 2002. Accounting for diffuse layer ions in triple-layer models. Journal of Colloid and Interface Science 250:492-495.

2606 Burger, J., K. F. Gaines, C. S. Boring, W. L. Stephens, J. Snodgrass, C. Dixon, M. McMahon, S. Shukla, T. Shukla, 
and M. Gochfeld. 2002. Metal levels in fish from the Savannah River: potential hazards to fish and other receptors. Environmental Research Section A. 89:8597.

2607 Dixon, P. M. 2002. Nearest-neighbor contingency table analysis of spatial segregation for several species. Ecoscience 9:142-151. 


\section{Foure 1. Organizational Chart for the Sevannah River Foology Laboratory}

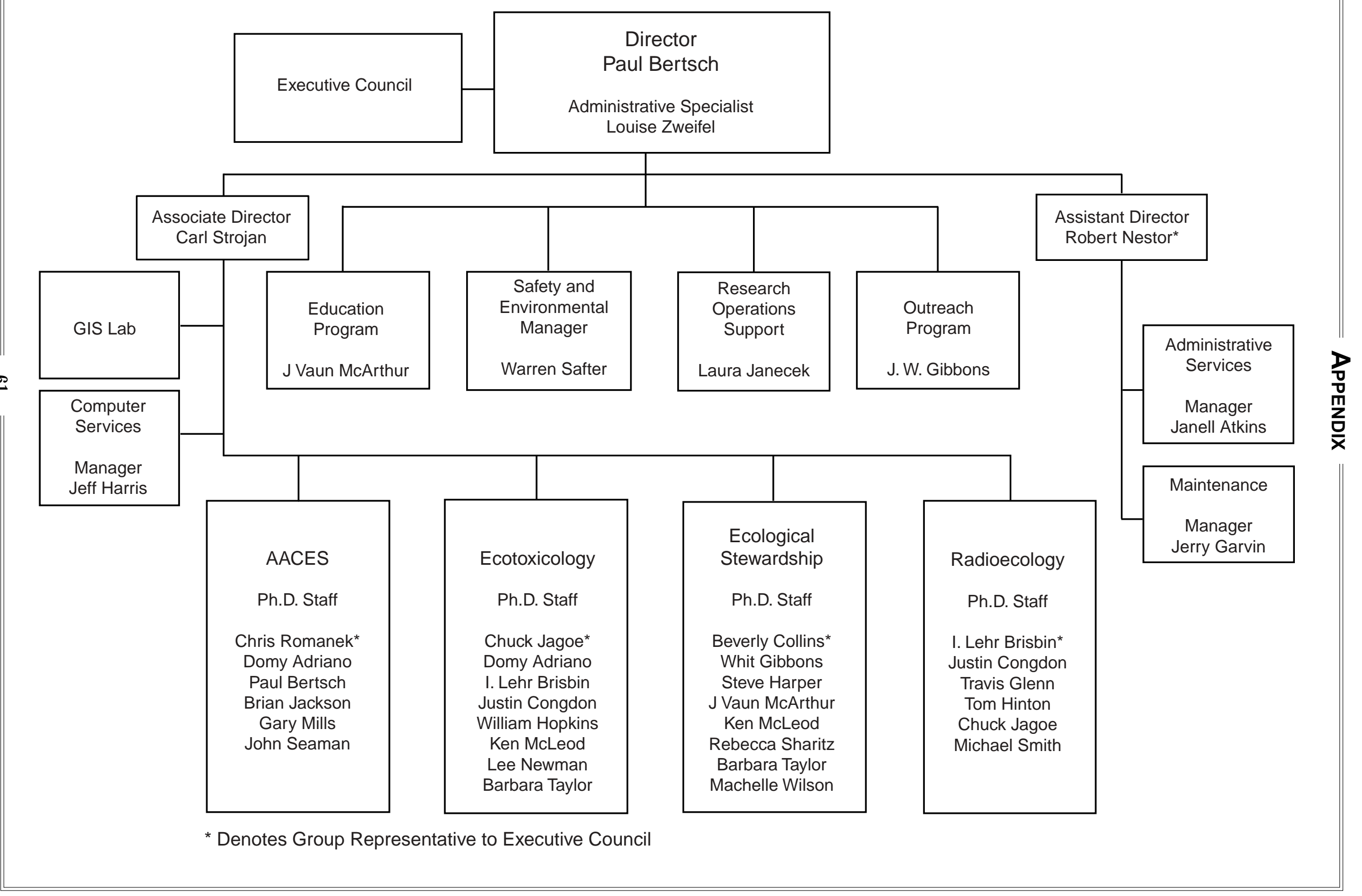




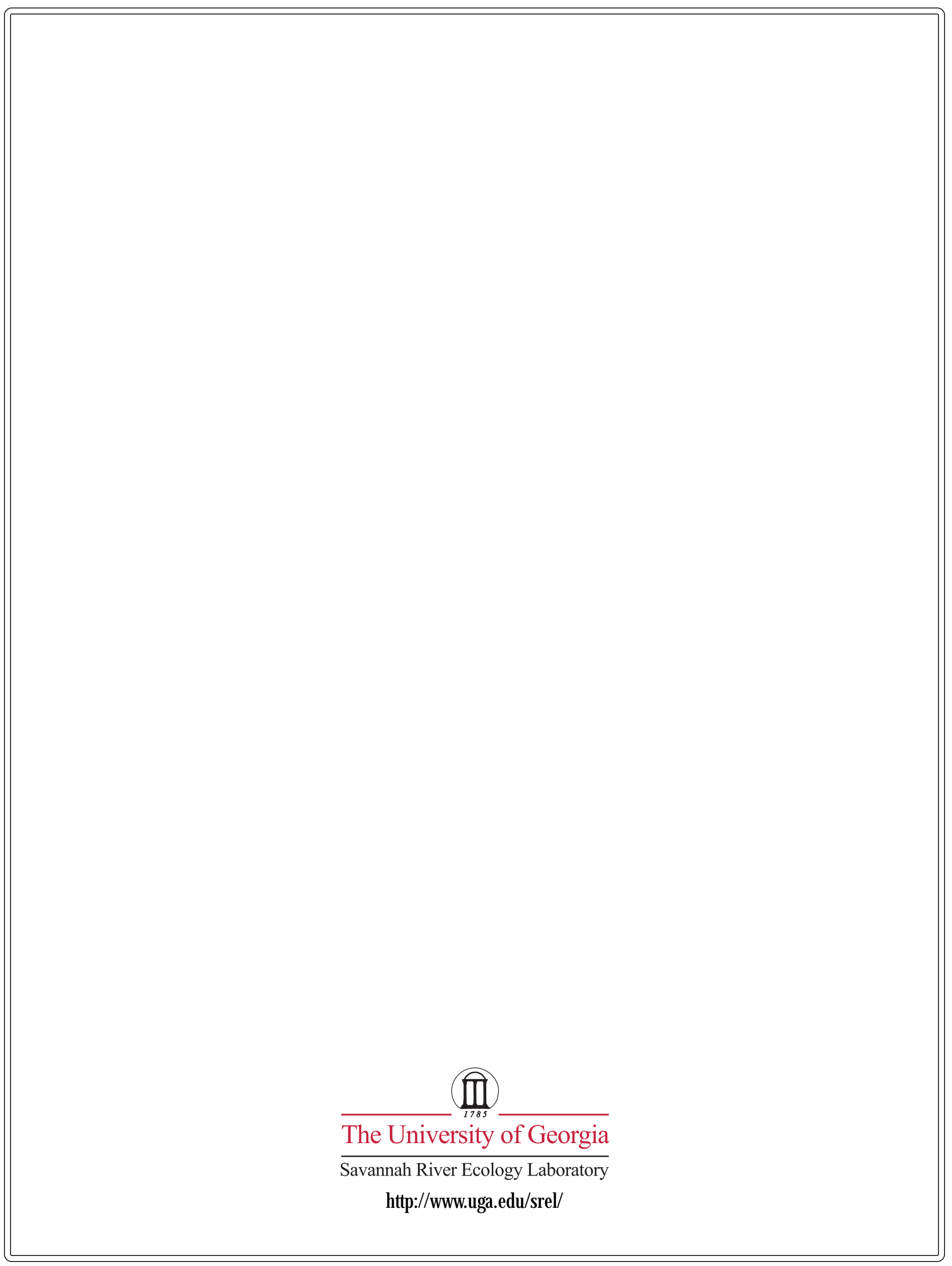

